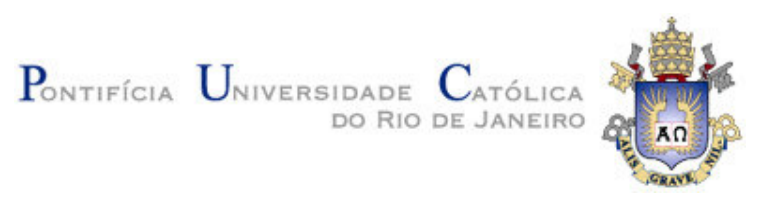

Felipe Ramos Gall

Da estranheza na era da técnica

Dissertação de Mestrado

Dissertação apresentada como requisito parcial para a obtenção do grau de Mestre pelo Programa de PósGraduação em Filosofia do Departamento de Filosofia do Centro de Teologia e Ciências Humanas da PUC-Rio.

Orientador: Prof. Edgar de Brito Lyra Netto 
Felipe Ramos Gall

\title{
Da estranheza na era da técnica
}

Dissertação apresentada como requisito parcial para a obtenção do grau de Mestre pelo Programa de PósGraduação em Filosofia do Departamento de Filosofia do Centro de Teologia e Ciências Humanas da PUC-Rio. Aprovada pela Comissão Examinadora abaixo assinada.

\author{
Prof. Edgar de Brito Lyra Netto \\ Orientador \\ Departamento de Filosofia - PUC-Rio
}

Profa. Ligia Teresa Saramago Paiva

Departamento de Filosofia - PUC-Rio

Prof. Gilvan Luis Fogel

Universidade Federal do Rio de Janeiro - UFRJ

Profa. Monah Winograd

Coordenadora Setorial do Centro de Teologia e Ciências Humanas - PUC-Rio 
Todos os direitos reservados. É proibida a reprodução total ou parcial do trabalho sem autorização da universidade, do autor e do orientador.

Felipe Ramos Gall

Licenciado em História, em 2013, e em Filosofia, em 2014, pela Universidade Católica de Petrópolis (UCP). Cursou o Mestrado em Filosofia pela PUC-Rio (2015-2017), na linha de pesquisa de História da Filosofia Contemporânea, na área de concentração de Fenomenologia. Possui artigos publicados em revistas especializadas e realizou apresentações de trabalhos em eventos na área de Filosofia, inclusive na ANPOF.

Ficha Catalográfica

Gall, Felipe Ramos

Da estranheza na era da técnica / Felipe Ramos Gall ; orientador: Edgar de Brito Lyra Netto. - 2017. $125 \mathrm{f}$; ; $30 \mathrm{~cm}$

Dissertação (mestrado)-Pontifícia Universidade Católica do Rio de Janeiro, Departamento de Filosofia, 2017.

Inclui bibliografia

1. Filosofia - Teses. 2. Heidegger. 3. Estranheza. 4. Técnica. I. Lyra Netto, Edgar de Brito. II. Pontifícia Universidade Católica do Rio de Janeiro. Departamento de Filosofia. III. Título. 
A Gilvan Fogel 


\section{Agradecimentos}

Aos meus pais, Marcos Antônio e Maria Teresa, por seu sacrifício constante em prol da realização dos meus sonhos;

Ao professor Edgar de Brito Lyra Netto, pelo zelo, solicitude e paciência na orientação deste trabalho;

Ao professor Gilvan Luiz Fogel, pelo exemplo, pela acolhida em suas aulas, pela importância que teve nesse meu caminho de pensamento, e por ter me dado a honra de aceitar ser um interlocutor deste trabalho;

À professora Ligia Teresa Saramago Paiva, pela leitura, contribuição e crítica, visando o aprimoramento deste trabalho;

Aos amigos e familiares, que direta ou indiretamente contribuíram para o desenvolvimento deste trabalho, apresentando questões e propondo discussões, ou ainda oferecendo sempre apoio e ajuda, e que também foram determinantes para o meu amadurecimento intelectual e pessoal;

À Pontifícia Universidade Católica do Rio de Janeiro, em especial ao Departamento de Filosofia, por possibilitarem tudo isso;

Ao Conselho Nacional de Desenvolvimento Científico e Tecnológico (CNPq), pela bolsa de estudos a mim concedida durante esses anos de estudo e pesquisa. 


\section{Resumo}

Gall, Felipe Ramos; Lyra Netto, Edgar de Brito. Da estranheza na era da técnica. Rio de Janeiro, 2017, 125p. Dissertação de Mestrado Departamento de Filosofia, Pontifícia Universidade Católica do Rio de Janeiro.

Tomando por base as considerações de Martin Heidegger acerca da técnica, segundo as quais o domínio da técnica vigente em nossos dias manifestase como a aparência de ser a única possibilidade de compreensão da realidade, sendo este o grande perigo de nossa época, nossa questão norteadora aqui é sobre a estranheza existencial e de sua possibilidade em nossa época. O fenômeno da estranheza é tematizado por Heidegger de modo mais pormenorizado em Ser e tempo, sua obra seminal. Tendo em vista o caráter histórico-ontológico deste trabalho, nosso ponto de partida será demonstrar as determinações históricas que conduziram Heidegger para a questão diretriz de Ser e tempo, isto é, o questionamento pelo sentido de ser. Havendo estabelecido isso, reconstruiremos os passos essenciais da analítica existencial que convém ao fenômeno da estranheza, visando demonstrar sua relação essencial com temas como a cotidianidade, angústia, cuidado, morte e autenticidade. A estranheza mostrar-se-á como um fenômeno inseparável da disposição de ânimo fundamental, que, em Ser e tempo, é a angústia. A questão da técnica, por sua vez, surge no pensamento tardio de Heidegger, isto é, após a virada em seu pensamento. Visamos demonstrar que após a virada não houve um abandono das conquistas obtidas em Ser e tempo, muito pelo contrário: as considerações acerca da estranheza tal como apresentadas na analítica existencial parecem ser imprescindíveis para a nossa hodierna tarefa do pensamento, pois a lida apropriada com a tecnologia e seus aparelhos parece exigir um estranhamento essencial de seu domínio inconcusso e indisputado.

\section{Palavras-chave}

Heidegger; Estranheza; Técnica 


\section{Abstract}

Gall, Felipe Ramos; Lyra Netto, Edgar de Brito (Advisor). On the uncanniness in the age of technology. Rio de Janeiro, 2017, 125p. Dissertação de Mestrado - Departamento de Filosofia, Pontifícia Universidade Católica do Rio de Janeiro.

Based on Martin Heidegger's considerations concerning technology, according to which the dominance of technology in force nowadays manifests itself as the appearance of being the only possibility of comprehension of reality, which is the great danger of our time, our guiding question here is about the existential uncanniness and its possibility in our time. The phenomenon of the uncanny is thematized by Heidegger in more detail in Being and time, his seminal work. Considering the historical-ontological character of this work, our starting point will be to demonstrate the historical determinations that led Heidegger to the guiding question of Being and time, that is, the questioning of the meaning of Being. Having established this, we will reconstruct the essential steps of the existential analytic that befits the phenomenon of uncanniness, aiming to demonstrate its essential relationship with themes such as the everydayness, anxiety, care, death and authenticity. Uncanniness will prove itself to be an inseparable phenomenon of the fundamental attunement, which, in Being and time, is the anxiety. The question concerning technology, on the other hand, appears in Heidegger's late thought, that is, after the turn in his thought. We aim to demonstrate, therefore, that after the turn there was no abandonment of the achievements obtained in Being and time, but quite the opposite: the considerations about the uncanny as presented in the existential analytic seem to be indispensable to our contemporary task of thinking, for the properly dealing with technology and its devices seems to require an essential uncanniness of its undisputed dominance.

\section{Keywords:}

Heidegger; Uncanniness; Technology 


\section{Sumário}

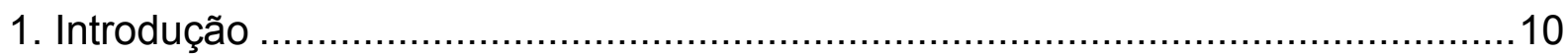

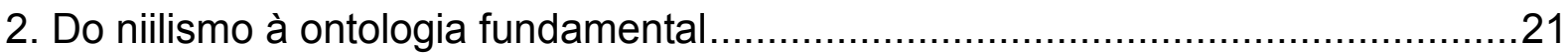

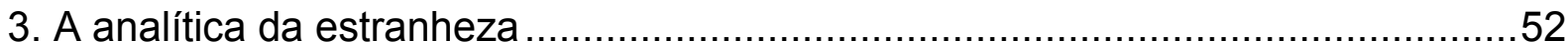

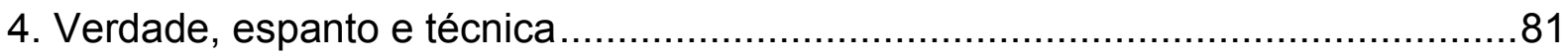

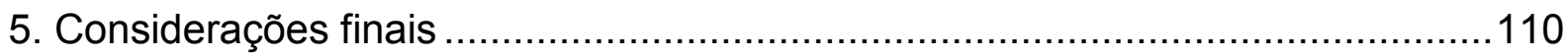

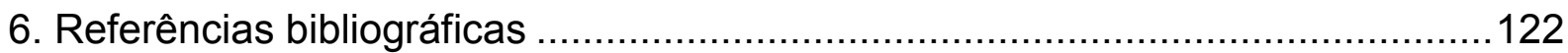

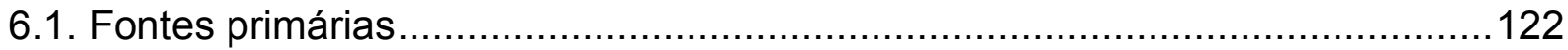

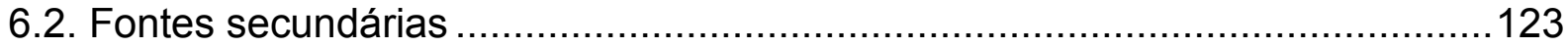

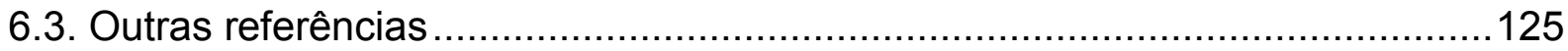


A vulgaridade é um lar. O quotidiano é materno. Depois de uma incursão larga na grande poesia, aos montes da aspiração sublime, aos penhascos do transcendente e do oculto, sabe melhor que bem, sabe a tudo quanto é quente na vida, regressar à estalagem onde riem os parvos felizes, beber com eles, parvo também, como Deus nos fez, contente do universo que nos foi dado e deixando o mais aos que trepam montanhas para não fazer nada lá no alto.

Bernardo Soares 


\section{INTRODUÇÃO}

Martin Heidegger iniciou a obra mais significativa do seu caminho de pensamento com o testemunho de uma perplexidade. O princípio de Ser e tempo é uma passagem do diálogo Sofista, de Platão. A passagem diz: “... pois é evidente que de há muito sabeis o que propriamente quereis designar quando empregais a expressão 'ente'. Outrora, também nós julgávamos saber, agora, porém, caímos em aporia"1. A aporia é a expressão dessa perplexidade. Temos o testemunho de Aristóteles $^{2}$ de que o encontrar-se em aporia, o aperceber-se que não se sabe

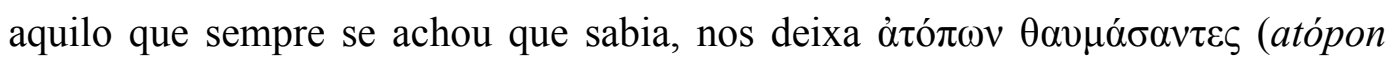

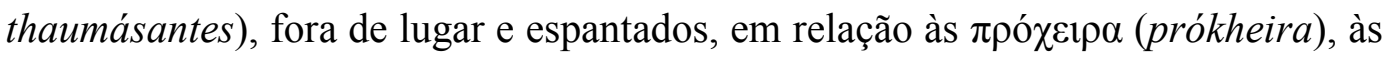
coisas à mão, próximas, ordinárias. Aquilo que tomávamos como óbvio mostrouse como desconhecido. O espanto dessa constatação seria o próprio princípio do filosofar.

Que queremos dizer, no entanto, quando afirmamos que alguma coisa está próxima de nós? Estar à mão significa meramente aquilo ao alcance de nossos dedos? De modo algum. A proximidade não é uma distância curta, pois não se trata aqui de nada espacial, ao menos não de algo espacial no sentido da física moderna. Quando o mundo é reduzido a um plano cartesiano, a distância passa a ser compreendida como o intervalo entre dois pontos. Um intervalo curto significaria que os pontos estão próximos. Partindo dessa concepção de proximidade, nunca seremos capazes de ouvir o poeta, quando ele diz que "os mais amados avizinham-se (habitam próximos) nas montanhas mais separadas"3. Ouvimos isso como irracionalidade, fantasia. E isso porque já lemos isso sabendo o que "próximo" e "distante" significam, e que são termos que se opõem. Se algo é próximo, logo não é distante, e vice-versa. Ou um ou outro. Desse modo, o poeta afirma uma contradição. Ele está logicamente equivocado. Que noção de proximidade está em jogo aqui?

\footnotetext{
${ }_{1}^{1}$ PLATÃO, O Sofista, 244a, apud HEIDEGGER, Ser e tempo, p. 34.

${ }^{2}$ Cf. ARISTÓTELES, Metafisica, A 982b11-19.

${ }^{3}$ Cf. HÖLDERLIN, "Patmos". Sämtliche Werke, vol. 2, p. 173, tradução livre de “... die Liebsten nahe wohnen (...) auf getrenntesten Bergen".
} 
No Evangelho segundo São Lucas encontra-se uma narrativa que nos conta que, certa vez, um doutor da lei questionou Cristo acerca do que ele teria que fazer para obter a vida eterna. A resposta de Cristo foi que ele cumprisse o que encontrava-se escrito na lei, a saber: “Amarás ao Senhor teu Deus de todo o teu coração, e de toda a tua alma, e de todas as tuas forças, e de todo o teu entendimento, e ao teu próximo como a ti mesmo"4. A narrativa nos conta que o doutor da lei, então, de modo a justificar-se, questiona: "E quem é o meu próximo?", . A resposta a esta pergunta foi a famosa parábola do bom samaritano ${ }^{6}$. Podemos afirmar com certeza que "próximo" aqui, tal como no verso de Hölderlin, não significa curta distância. Não seria um mandamento para amarmos somente as pessoas que se encontram imediatamente ao nosso redor. Comentando essa passagem, Kierkegaard diz: 'O conceito do 'próximo' é propriamente a reduplicação da tua própria identidade; 'o próximo' é o que os pensadores chamariam de 'o outro', aquele no qual o egoístico do amor de si é posto à

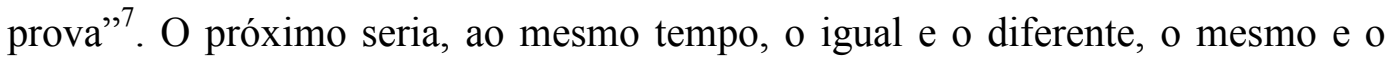
outro, o familiar e o estranho. Do ponto de vista da lógica, não nos deparamos com outro paradoxo? Como é possível sermos outro, sermos estranhos, e ainda assim sermos nós próprios ao mesmo tempo? Porque é justamente isso que Kierkegaard intuiu: para além de quaisquer respostas "corretas", que entendem claramente que o bom samaritano "amou o próximo como a si mesmo", o que está em jogo aqui de modo essencial é que o samaritano só foi capaz disso porque ele se tornou o próximo do outro ${ }^{8}$. Ao nos tornarmos outro, nós próprios somos o próximo. É isso que dá a medida do amor de si para além de qualquer egoísmo. E é com base nessa medida existencial - que não se obtem por meio de nenhum cálculo - que faz sentido falarmos de amar ao próximo como a si mesmo.

Ser si-mesmo como outro, ser estranho, ser estrangeiro. Temos aqui ao menos a sinalização de que isso é o fundamento do mandamento do amor, do amor caritativo, o amor que doa para além de si, porque sobra, transborda, transcende. Também as coisas próximas a nós obedecem a isso, pois o amor é de

\footnotetext{
${ }^{4}$ Lc 10:27.

${ }^{5}$ Lc 10:29.

${ }^{6}$ Cf. Lc:30-36.

${ }^{7}$ KIERKEGAARD, As obras do amor, pp. 35-36.

${ }^{8}$ Idem, ibidem, p. 38 .
} 
uma natureza tal que transforma o homem nas coisas que ele ama ${ }^{9}$. Lidamos com coisas a todo momento. Diversas coisas estão à nossa disposição todos os dias, em todos os momentos. Ocorre que elas normalmente não se mostram enquanto coisas, mas sim enquanto isso ou aquilo, uma caneta ou uma garrafa, por exemplo. Nossa relação com as coisas já sempre se deu a partir de uma compreensão e de uma afinação para com elas propiciada por uma disposição de ânimo. É isso que concede a elas o caráter de familiaridade. Essa familiaridade faz com que as coisas estejam próximas, que estejam à mão. Nossa lida mais imediata para com as coisas se dá a partir do modo de ser da manualidade. Isso é o que há de mais familiar em nosso horizonte de sentido e significatividade, em nosso mundo. Essa proximidade do familiar, com efeito, nada tem a ver com distância, tampouco o estar à mão das coisas tem a ver com a presença efetiva delas à vista. Algo pode ser próximo, mesmo que efetivamente esteja longe. Quando percebemos uma coisa como algo presente à vista e calculamos sua distância em relação a nosso corpo, já não nos encontramos próximos da coisa, ela já não se mostra à mão, mesmo que esteja literalmente "no nosso nariz", ao alcance de nossos dedos.

Quando acontece de sermos dispostos de certo modo, essa familiaridade com as coisas parece se dissolver. O que era familiar e habitual mostra-se estranho, ao passo em que também nós nos apercebemos estranhos. É nesse instante que a coisa se mostra enquanto coisa, e é nesse momento de perplexidade que surge a filosofia. Percebendo a coisa enquanto coisa, evidencia-se que o sercoisa da coisa é, no fundo, doação (Schenken). A essência da coisa é a dádiva (das Geschenk) de $\operatorname{ser}^{10}$. Dá-se ser, sem porquê nem para quê. Por mais caro que tenhamos comprado alguma coisa, de modo essencial ela ainda é doação. De acordo com Heidegger, essa relação de cumplicidade para com as coisas era o que definia a técnica antiga, tal como entendida pelos gregos. Produzir algo era dar passagem para essa doação da coisa, deixar-viger a coisa por ela mesma ${ }^{11}$. Algo bem diferente se dá com a técnica moderna, que impede justamente o livre deixarser da coisa, e violentamente a dispõe como insumo e reserva. É por hodiernamente nós prioritariamente representarmos as coisas como essa

\footnotetext{
${ }^{9}$ Cf. MESTRE ECKHART, Sermões alemães, vol. 2.

${ }^{10} \mathrm{Cf}$. HEIDEGGER, A coisa. In: ___ : Ensaios e conferências, p. 149.

${ }^{11}$ Cf. HEIDEGGER, A questão da técnica. In: ___ : Ensaios e conferências, p. 16 ss.
} 
disponibilidade que podemos julgar as coisas pela sua utilidade imediata e a elas atribuir valor. Nessa perspectiva, a filosofia seria um exercício e uma experiência de pobreza, entendida de modo originário, que percebe a dádiva de ser para além de qualquer possível valor das coisas tomadas habitualmente. Se perdermos de vista essa noção de proximidade para com as coisas, portanto, teremos como único critério o cálculo. Cálculo que estipula valores, que determina distâncias. Nesse plano cartesiano, que impera teimosamente como nossa representação padrão do mundo, podemos encaixar todas as coisas em seus devidos lugares, e somos capazes de estipular e estabelecer valores a todas as coisas. Isso não seria justamente o que é mais digno de estranheza?

Nosso mundo contemporâneo alardeia constantemente que estamos diminuindo as distâncias e superando barreiras. Sob o domínio da técnica, o mundo diminui e encolhe. As distâncias são cada vez menores, graças a uma série de avanços tecnológicos. Contudo, de modo algum podemos afirmar que, por causa disso, as coisas hoje estão mais próxima de nós do que antes. Uma pequena cidade pacata do interior era todo um mundo para aqueles que nela nasceram, viveram toda a vida e morreram, seguindo os passos de seus antepassados. Ir à cidade vizinha em busca de comércio já era em si uma aventura. Ouvir as narrativas dos viajantes que estiveram em outros países e testemunharam outras culturas, outros hábitos, outros deuses, outro modo de vida, tinha um quê de mítico e folclórico. Hoje, a notícia de um cataclisma ocorrido literalmente do outro lado do globo chega aos nossos ouvidos em questão de segundos. Em minutos, senão também em segundos, já temos imagens do que aconteceu. O assunto rapidamente se torna um dos mais comentados do mundo nas redes sociais, e só os "alienados" chegarão ao final desse dia sem saber o que aconteceu. Entretanto, em questão de dias, essa informação é esquecida pela ampla maioria, pois uma nova notícia tomou o seu lugar, já que, naturalmente, os acontecimentos não param. O incrível é que um evento ocorrido do outro lado do globo nos traz uma sensação de proximidade. Temos a ilusão da proximidade. Por um lado, porque não importa o lugar em que tenha ocorrido a catástrofe, ele será realmente "próximo", pois não é nada que algumas horas de avião não resolvam. Ademais, esse lugar nos parece próximo em outro sentido: vemos as imagens do ocorrido, e as pessoas se vestem de modo parecido com o nosso, usam aparelhos parecidos, 
exercem funções parecidas na sociedade. Se este não for o caso, isto é, se for um lugar "exótico", não nos causará estranheza tampouco, pois já ouvimos falar dele e de suas peculiaridades em alguma matéria de revista, reportagem de TV ou mesmo em guias de turismo. A dimensão do fantástico que as antigas narrativas dos exploradores gerava se perdeu. Basta visitar o lugar e ver com seus próprios olhos se o que foi contado é o caso ou não, ou assistir a algum documentário sobre o local, não há mistério.

A total exploração do mundo impossibilita aquela vertigem dos antigos navegadores ao se lançarem ao mar em busca do desconhecido, aquela coragem de jogar-se em direção ao nada, ao irrepresentável. Mas esse afã não desapareceu. A saída, portanto, é a exploração do espaço sideral, a última fronteira. O mistério do mundo é transferido dos vastos mares e das densas florestas para o gélido silêncio do espaço, que parece ser o único lugar ainda capaz de nos passar a sensação de distância, de um longínquo horizonte desconhecido que grassa rumo ao abismo. No entanto, nossa relação para com o universo e sua exploração, e, no limite, conquista, é a de um "ainda não". Conseguiremos, isto é fato, ninguém duvida; ainda não somos capazes, mas é questão de tempo. Temos a chave que abre todos os segredos do cósmos: os avanços tecnológicos. Importa pois deixar que a roda de seu progresso gire continuamente, infinitamente, pois uma hora ela irá adequar-se à grande fechadura do universo que impõe-se ante a humanidade e nos desafia.

Tais avanços tecnológicos, outrora operados em progressão aritmética, desde há muito escalonaram para uma progressão geométrica, cujos resultados potencializam-se em tal ordem que qualquer previsão de limite é praticamente impossível, a não ser que se leve em conta a possibilidade de esgotamento dos recursos do próprio planeta e a consequente extinção da vida humana, ao menos tal como nós a conhecemos. Inovação, consumo e obsolescência operam uma dialética perversa que nos condena a todos. Mais perigosa do que esta dialética, no entanto, não é o próprio questionar que a põe em xeque? Não se estaria assim indo contra o "progresso", advogando um claro retrocesso civilizacional? E o que dizer da hipocrisia, pois este texto mesmo utiliza-se de um computador, de energia elétrica etc.? Questionar, estranhar esta ideologia dominante - qual seja, a do consumo desenfreado e da fé inabalável na tecnologia, no fundo, da soteriologia 
da ciência, isto é, de que a ciência trará a "salvação", garantirá nossa "felicidade", proporcionará nosso "bem estar" - soa a ingratidão, cinismo e mau-caratismo. Quem pode ser contra a felicidade, contra um mundo melhor, mais seguro, mais rápido, mais prático, mais eficiente...?

Nesse mundo dominado pela ciência e pela tecnologia, faz ainda algum sentido falar em filosofia? A filosofia "já não deu o que tinha que dar"? Parece que hoje ela ainda sobrevive apenas porque é capaz de despertar curiosidade, é um tema chique, valoroso como erudição, um produto de alta cultura para pessoas sofisticadas, que não querem parecer ignorantes ou pobres de espírito nas redes sociais, nos cafés ou nas academias de ginástica. A filosofia compreendida desse modo, como uma "coisa", logo, como uma mercadoria acessível a todos que estejam dispostos a pagar, está bastante viva, não corre o menor risco de acabar. Ela facilmente vira auto-ajuda, tema de palestra motivacional, ou um punhado de frases de efeito, ideais para serem compartilhadas na internet. Mas e a filosofia compreendida de modo essencial, como aquela experiência de pensamento que funda as eras da história? Experiência de transformação, que ressignifica a existência, que cobra um preço tal que dinheiro nenhum do mundo seria capaz de pagar? Essa filosofia é uma tarefa árdua, que exige um custoso sacrifício. Ela exige também a paciência da espera, porque ela não se dá nem nunca se dará quando nós queremos, mas sempre quando ela quer, impondo-se. Nesse mundo onde estamos sempre com pressa, e tudo precisa ser mais veloz, somos capazes de uma tal paciência? Nesse mundo onde toda dor deve ser erradicada, onde o menor sinal de sofrimento já deve logo ser medicado, somos capazes de um tal sacrifício doloroso?

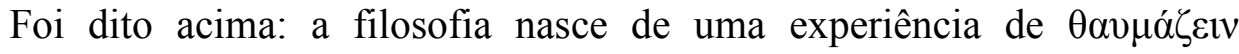
(thaumázein), de espanto. Esse espanto não é nenhum sentimento, não é nada psicológico. Esse espanto é, na linguagem do pensamento de Heidegger, uma disposição de ânimo (Befindlichkeit). Sendo algo que nos dispõe, que transcende tudo da ordem do subjetivo e objetivo, do "físico", é um erro achar que esse espanto é causa do filosofar. Nem o espanto é uma causa, nem a filosofia é um efeito, pois não se trata de nada "natural", "físico". O espanto, enquanto disposição, é algo originário. Originário (ursprünglich) não significa origem no sentido de começo, início temporal, passado. Não é o mesmo que original, 
portanto. Originário seria aquilo que efetivamente nunca foi, mas que sempre é. Não foi marco temporal algum, data histórica alguma, mas sempre é no sentido em que vigora e perpassa a coisa. Não se tem o sentimento de espanto como algo pontual, e daí se começa a filosofar. Tomados e dispostos pelo espanto, ele vigora e perpassa todo o filosofar. Somos tocados e tomados por essa disposição, como se viu, quando uma aporia nos deixa perplexos: aquilo que antes era o mais conhecido agora mostra-se como algo estranho. Santo Agostinho nos apresenta isso de modo genial:

Que é, pois, o tempo? Quem poderá explicá-lo clara e brevemente? Quem o poderá apreender, mesmo só com o pensamento, para depois nos traduzir por palavras o seu conceito? E que assunto mais familiar e mais batido nas nossas conversas do que o tempo? Quando dele falamos, compreendemos o que dizemos. Compreendemos também o que nos dizem quando dele nos falam. O que é, por conseguinte, o tempo? Se ninguém mo perguntar, eu sei; se o quiser explicar a quem me fizer a pergunta, já não $\operatorname{sei}^{12}$.

A pergunta pelo quê, pelo quid, pelo tí das coisas: é isso o que é próprio da filosofia. Questionar o ser das coisas. Temos, hoje mais do que nunca, a impressão de que tudo é conhecido, ou ao menos que basta uma rápida busca na internet para que nos informemos e passemos, pois, a conhecer qualquer coisa. $\mathrm{O}$ homem moderno vê o questionamento de Agostinho com bazófia. "Que é o tempo? Basta pesquisar o que disse Einstein!”. Nenhum questionamento essencial é digno de meditação, isto é, de um esforço para um pensamento capaz de apreender seu sentido. Os questionamentos são vistos como desafios. Basta uma pesquisa ou uma nova descoberta para que obtenhamos nossa resposta, é uma mera questão de tempo, diligência e paciência. Todavia, se o que é próprio da filosofia é ficar sempre questionando a mesma coisa, ela, que sempre foi tida como inútil, não seria ainda mais inútil em nossos dias? E se temos o hábito de valorizar apenas aquilo que é imediatamente útil, não convém que a filosofia seja desvalorizada? Somos hoje capazes de falar tantas coisas diferentes a respeito de cada coisa, há ainda a necessidade de "abstrações filosóficas", de teorias elaboradas e fajutas que não servem para nada?

Havia, em tempos antigos, um famoso mestre grego que viajava a todos os lugares ensinando. Tais pessoas eram chamadas de sofistas. Uma vez este sofista famoso, retornando a Atenas após

${ }^{12}$ AGOSTINHO, Confissões, XI, 14, pp. 243-244. 
ter dado aulas na Ásia Menor, conheceu Sócrates na rua. Sócrates tinha o hábito de andar pelas ruas e falar com as pessoas, com um sapateiro, por exemplo, e perguntar a ele o que é um sapato. Sócrates não tinha outro assunto a não ser o que as coisas são. "Ainda encontra-se parado aí", perguntou o muito viajado sofista de modo condescendente a Sócrates, "e ainda está dizendo a mesma coisa acerca da mesma coisa?" "Sim", respondeu Sócrates, "estou. Mas você, que é tão extremamente esperto, você nunca diz a mesma coisa sobre a mesma coisa" ${ }^{\prime 13}$.

Somos hoje como os sofistas da Antiguidade. Sabemos muitas coisas, temos muitas coisas a ensinar. Somos muito viajados e conhecemos muitos lugares. E é com desdém que olhamos para o questionamento filosófico, quase que com dó, ao nos depararmos com a perda de tempo com a qual uma pessoa voluntariamente se submete a algo tão inútil. Já desde a Antiguidade havia narrativas sobre o escárnio das pessoas comuns em relação a filosofia. Há, por exemplo, a famigerada anedota que nos conta do riso de uma escrava trácia ao ver que Tales de Mileto, andando distraído enquanto olhava para o céu, pois desejava conhecer os mistérios celestes, acabou caíndo em um buraco, pois se esqueceu de olhar para os próprios pés ${ }^{14}$. Dado que Tales é considerado o primeiro filósofo, não seria exagero afirmar que o desdém pela vida filosófica surgiu concomitantemente com a própria filosofia. Desde que há filosofia, há também o deboche do senso comum em relação a ela. Esse senso comum nada mais é que o "saudável entendimento humano" (der gesunde Menschenverstand), nosso "bom senso" que teima em se apegar àquilo que é imediatamente útil ou àquilo que se mostra valoroso, ou seja, àquelas coisas que "ninguém em sã consciência" seria capaz de rejeitar. Em sã consciência, todos queremos o que nos é útil. De fato. Mas há aqueles que dedicam suas vidas a algo que, a primeira vista, é completamente inútil: a filosofia. É ridículo ver alguém “jogando a vida fora”,

\footnotetext{
${ }^{13}$ HEIDEGGER, What is a thing?, pp. 73-74. Tradução livre de: "There was, in ancient times, a famous Greek scholar who traveled everywhere lecturing. Such people were called Sophists. Once this famous Sophist, returning to Athens from a lecture tour in Asia Minor, met Socrates on the street. It was Socrates' habit to hang around on the street and to talk with people, with a cobbler, for instance, over what a shoe is. Socrates had no other topic than what the things are. 'Are you still standing there', condescendingly asked the much traveled Sophist of Socrates, 'and still saying the same thing about the same thing?' 'Yes', answered Socrates, 'that I am. But you who are so extremely smart, you never say the same thing about the same thing'."

Platão põe na boca do personagem Cálicles, no Górgias (491a), uma indignação parecida: "Pelos deuses! Só falas em sapateiros, tecelões, cozinheiros e médicos, como se isso tivesse alguma coisa a ver com a nossa discussão".

${ }^{14}$ Cf. PLATÃO, Teeteto, $174 \mathrm{a}$, bem como DIÓGENES LAÉRCIO, Vidas e doutrinas dos filósofos ilustres, I, §34, p. 21.
} 
desperdiçando o precioso e curto tempo que nos foi dado tratando de questões inúteis, dedicando a vida a algo que muito provavelmente não nos trará o menor prestígio, e muito menos "dará dinheiro". Só pode ser loucura. Hegel assevera: "A filosofia, segundo a sua própria natureza, é algo de esotérico (...); para o senso comum, o mundo da filosofia é um mundo às avessas" ${ }^{\prime 15}$. Achamos graça dos loucos, da sua excentricidade, do seu caráter imprevisível, que sempre surpreende porque justamente escapa ao padrão. Mas esse riso tem por detrás um caráter de dó, de pena. "Que pena que ele não é normal como a gente", "que pena que ele passará a vida toda desse jeito". Platão, no Górgias, nos apresenta essa posição a partir de seu personagem Cálicles, que confronta Sócrates dizendo:

A filosofia, Sócrates, é de fato muito atraente para quem a estuda com moderação na mocidade, porém acaba por arruinar quem a ela se dedica mais tempo do que fora razoável. (...) De fato, não somente desconhecerá as leis da cidade, como a linguagem que será preciso usar no trato público ou particular, bem como carecerá de experiência com relação (...) às paixões $\mathrm{e}$ ao caráter geral dos homens. Logo que procuram ocupar-se com seus próprios negócios ou com a política, tornam-se ridículos, como ridículos, a meu ver, também se tornam os políticos que se dispõem a tomar parte em vossas reuniões e vossas disputas ${ }^{16}$.

A filosofia teria seu valor na juventude, como uma erudição que ajudaria o jovem a ser melhor formado e, por conseguinte, possibilitaria a ele um maior destaque entre seus pares quando fosse exercer a carreira política. Haveria aí, nesse caso, um valor para a filosofia, pois ela seria útil. Mas bastaria o jovem tornar-se adulto e iniciar de fato a vida política, e ter de passar a se preocupar com as questões sérias envolvendo o destino de sua cidade, para que a filosofia já se mostrasse como inútil, pois seria como que uma brincadeira ou um saber vazio quando comparado ao que estava em jogo nessa situação. Insistir em se dedicar a filosofia mesmo depois de jovem é ridículo, só um idiota trocaria as questões relevantes da vida política pelas questões abstratas e inúteis da filosofia. Ou ainda: teimar em se dedicar à vida filosófica seria um ato de extrema vaidade, de um egoísmo arrogante, de gente que se acha melhor do que os outros. Temos o testemunho de Aristóteles de que "todas as outras ciências serão mais necessárias que esta [a filosofia primeira], mas nenhuma lhe será superior" ${ }^{\prime 1}$. O filósofo se

\footnotetext{
${ }^{15}$ Apud BORNHEIM, Introdução ao filosofar, p. 62.

${ }^{16}$ PLATÃO, Górgias, $484 \mathrm{c}-\mathrm{e}$.

${ }^{17}$ ARISTÓTELES, Metafisica, A 2, 983a10s.
} 
dedica àquele saber que é superior a todos os demais, ele põe-se acima dos reles mortais, e por conta disso se vê no direito de impor-se como a medida, o critério. Novamente Cálicles diz a Sócrates: "Se é sério e for verdade tudo o que disseste, então a vida dos homens está completamente revirada, e nós agimos, ao que parece, exatamente ao contrário de como fora preciso proceder" ${ }^{\prime 18}$. A filosofia, que é o mundo cotidiano às avessas, propõe esse avesso como a regra, ela estabelece o certo e o errado. Entretanto, nosso senso comum e a revolta do óbvio têm sua razão de ser. Não estão "errados". Não devem ser erradicados, de modo algum. Também nós nos apegamos ao útil, nos irritamos com impaciência ante algo que entendemos como uma "perda de tempo".

Com efeito, todos nós sabemos, de um jeito ou de outro, o que é certo e errado: trata-se de uma questão de bom senso. Ninguém precisa estudar filosofia para julgar isso. Descartes inicia seu Discurso do método dizendo: "O bom senso é a coisa mais bem distribuída do mundo, pois cada um pensa estar tão bem provido dele, que mesmo aqueles mais difíceis de se satisfazerem com qualquer outra coisa não costumam desejar mais bom senso do que têm"19. Todos nós nos achamos providos de bom senso, e por conta disso tendemos a não questionar de fato as coisas, pois tudo se apresenta a nós como sendo óbvio. Daí surge o embate do senso comum com a filosofia: este incessante questionar da filosofia não é, além de inútil, vaidoso? Pois para quê precisamos ficar perguntando, a todo momento, acerca daquelas coisas que já sabemos o que são?

Esses são os questionamentos que aqui nos movem. Almejamos conseguir pôr essas questões apropriadamente. Todas elas derivam de nossa questão diretriz, a saber, se somos ainda capazes de um autêntico e criador estranhamento da representação do mundo que vige e impera na era da técnica. Para tanto, os capítulos a seguir se propõem a atravessar o pensamento de Martin Heidegger tendo como fio condutor o tema da estranheza. O primeiro capítulo se propõe a partir das determinações históricas que constituem, de certo modo, a gênese da ontologia fundamental desenvolvida por Heidegger em Ser e tempo como analítica existencial do ser-aí. De modo especial, vamos nos ater à noção de "niilismo" de Friedrich Nietzsche, bem como do embate deste com o platonismo,

\footnotetext{
${ }^{18}$ PLATÃO, Górgias, 481c.

${ }^{19}$ DESCARTES, Discurso do método, I, p. 5.
} 
ou seja, com a metafísica. Ademais, trataremos nesse capítulo, de modo mais pormenorizado, dos principais conceitos da analítica existencial, de acordo com nosso propósito aqui. O segundo capítulo, por sua vez, visa aprofundar os conceitos e a problemática de Ser e tempo trabalhados anteriormente, dando clara ênfase ao tema da estranheza propriamente dito, tal como ele aparece nesta obra, em relação com a disposição de ânimo fundamental da angústia, passando por conceitos caros ao pensamento heideggeriano, tais como o impessoal, o cuidado e a morte. O propósito é demonstrar a importância do fenômeno da estranheza para entendermos o que significa a propriedade ou autenticidade do ser-aí. O terceiro capítulo, por fim, parte da virada no pensamento de Heidegger, que deixou incompleto o projeto de Ser e tempo, com o intuito de analisar um tema caro desse seu pensamento pós-virada: a meditação sobre a história do ser, de modo a estabelecer e fundamentar o porquê de haver um domínio expresso da técnica em nossa época histórica. Mostrar a passagem da estranheza do ser-aí para a estranheza do próprio ser, bem como sua reciprocidade, pois somos justamente ser-aí. A intenção aqui, por conseguinte, é mostrar que não houve um abandono das conquistas obtidas em Ser e tempo; muito pelo contrário: as considerações acerca da estranheza tal como apresentadas na analítica existencial parecem ser imprescindíveis para a nossa hodierna tarefa do pensamento. Lidar com a tecnologia deve passar por um estranhamento de seu domínio inconcusso e indisputado. Da estranheza nasce a criação, a liberação do próprio de cada ser-aí, a arte no sentido mais originário. Talvez a nossa salvação venha desta arte. 


\section{Do niilismo à ontologia fundamental}

Os metafísicos de Tlön não buscam a verdade nem sequer a verossimilhança: buscam o assombro ${ }^{1}$.

Jorge Luis Borges

Qual é a questão derradeira da filosofia? Se formos nos escorar na autoridade do pensamento de Immanuel Kant, por exemplo, ele dirá de modo decisivo que a questão mais fundamental é: "Que é o homem?" (Was ist der Mensch? $)^{2}$. Kant, com sua filosofia crítica, buscou responder ao menos três questões: "Que posso saber?" (Was kann ich wissen?); "Que devo fazer?” (Was soll ich tun?); "Que me é permitido esperar?" (Was darf ich hoffen?); suas respostas provém, respectivamente, da metafísica, da moral e da religião. No entanto, essa quarta questão, a questão pela essência do humano, é, segundo Kant, o fundamento das demais, pois as outras três supramencionadas, no limite, a pressupõem. Ora, mas iniciarmos nossas considerações impondo esta pergunta soa como uma violenta arbitrariedade. Talvez. Ademais, o quão importante pode ser esta questão? Heidegger mesmo comenta, ironicamente, que "o que é o homem, cada qual o sabe"3. É óbvio, para todos, o que é o homem. Basta perguntar a qualquer um na rua que rirão de você, apontando para qualquer transeunte que passa, ou até mesmo indicando que nós mesmos, que discutimos isso, somos homens, é evidente. Para além dessa constatação mais imediata, há, de modo mais formal, diversas respostas, advindas de variadas áreas do saber. Para a biologia e antropologia, o homem é um vivente, um animal da espécie dos primatas superiores, com um cérebro altamente desenvolvido; para a sociologia, o homem é um animal político, definido por seu contexto social; para a teologia ocidental, o homem é a imagem e semelhança do Deus criador etc. Longe de nós aqui discutirmos o acerto ou a falsidade dessas teses. Contudo, todas elas têm algo em comum: elas determinam o homem a partir do ente, ele é um ente entre outros que

\footnotetext{
${ }^{1}$ BORGES, Tlön, Uqbar, Orbis Tertius. In: __ . Ficções, p. 22.

${ }^{2}$ KANT, Manual dos cursos de Lógica geral, p. 53.

${ }^{3}$ HEIDEGGER, $A$ essência da verdade. In: Marcas do caminho, p. 199.
} 
se distingue por tal e tal característica. Mas lidar com o homem a partir do ente implica uma compreensão prévia do que "ente" significa.

Cada ciência abrange e lida com uma região temática de entes. A biologia lida com o ente enquanto vida, a química, com o ente enquanto matéria etc. Nenhuma delas chega a pôr para si - e nem precisam disso - a questão mais radical, o questionamento acerca do ente enquanto ente. Essa é, segundo Heidegger, a questão própria da filosofia: $\tau$ í $\tau o ̀$ őv; (tí tò ón? $)^{4}$, que é o ente? Questiona-se o que o ente é. Há aí por detrás uma interpretação pressuposta do ser. O estudo do ser é por todos conhecido como metafísica. Estranhamente, o termo metafísica, que tornou-se em alguma medida sinônimo da própria filosofia, não consta em nenhum texto dos grandes filósofos da Antiguidade. Não se tratava de um conceito, tampouco de uma disciplina. No entanto, a literatura especializada, os manuais e as variadas histórias da filosofia não poucas vezes fazem referência à "metafísica" de determinado filósofo, separando-a e pondo-a ao lado de sua "epistemologia", "lógica", "estética", "ética" e "política". "Filosofia", assim, seria o nome dado ao compêndio dessas áreas do saber, dessas contribuições à alta cultura da humanidade.

Seguindo nessa direção, a metafísica é uma parte da filosofia, não nos importando aqui, ao menos de início, nenhuma questão mereológica. Qual parte? Em sentido clássico, seguindo as orientações de Aristóteles, que diz que uma

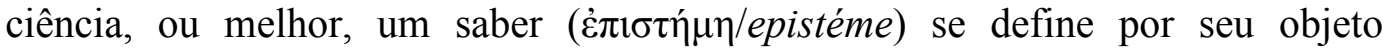
( $\pi \rho \alpha ́ \gamma \mu \alpha /$ prágma), a metafísica seria aquele saber que se ocupa (1) das causas últimas do ente e dos primeiros princípios 5 (“aitiologia”); (2) do ente enquanto ente $^{6}$ ("ontologia"); (3) da entidade ou substância 7 ("ousiologia"); e (4) de Deus, do divino ou das substâncias supra-sensíveis ${ }^{8}$ ("teologia"). Ora, mas se o termo "metafísica" era desconhecido por Aristóteles, bem como por todos os pensadores anteriores a ele, que direito temos de afirmar que o Estagirita nos oferece essas definições de metafísica?

\footnotetext{
${ }^{4}$ Cf. ARISTÓTELES, Metafísica, Z, 1, $1028 \mathrm{~b} 2$ ss.

${ }^{5} \mathrm{Cf}$. Idem, ibidem, livros A, $\alpha$ e B.

${ }^{6} \mathrm{Cf}$. Idem, ibidem, livros $\Gamma$, E e K.

${ }^{7} \mathrm{Cf}$. Idem, ibidem, livros $\mathrm{Z}, \mathrm{H}$ e $\Theta$.

${ }^{8} \mathrm{Cf}$. Idem, ibidem, livros $\mathrm{E}$ e $\Lambda$.
} 
$\mathrm{Na}$ verdade, essas definições supramencionadas referem-se àquilo que

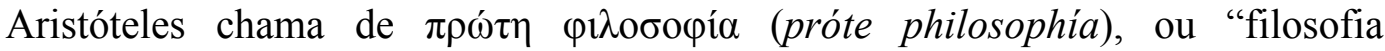
primeira", a filosofia por excelência, que seria o mais elevado dos saberes, seguido da física, ou "filosofia segunda", e da matemática, onde estas três

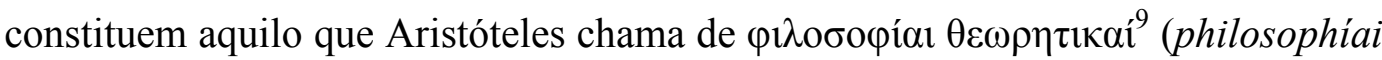
theoretikai), as filosofias ou saberes teoréticos, que são os saberes propriamente ditos por tratarem daquilo que é universal e por serem fins em si mesmos, isto é, sua razão de ser não depende de nenhuma aplicação prática ou da produção de algo. Contudo, se todos os três saberes em questão são teoréticos e dizem respeito ao universal, porque um deles foi eleito como o primeiro dentre eles, sendo, pois, o mais excelente?

Mas se existe algo eterno, imóvel e separado, é evidente que o conhecimento dele caberá a uma ciência teorética, não porém à física, porque a física se ocupa de seres em movimento, nem à matemática, mas a uma ciência anterior a uma e a outra. (...) Com efeito, se existe o divino, não há dúvida de que ele existe numa realidade daquele tipo (i.e., separada e imóvel). E também não há dúvida de que a ciência mais elevada deve ter por objeto o gênero mais elevado de realidade. Enquanto as ciências teoréticas são preferíveis às outras ciências, esta, por sua vez, é preferível às outras duas ciências teoréticas ${ }^{10}$.

É dizer: a filosofia primeira é "primeira" porque tem por objeto o mais elevado dos objetos possíveis, Deus. O esforço de Aristóteles é mostrar a necessidade da existência de uma realidade transcendente ("supra-lunar") como a melhor explicação para o problema do devir e do movimento na realidade imanente ("sub-lunar") ${ }^{11}$. E, por conseguinte, ele não hesita em afirmar: "Ora, se não existisse outra substância além das que constituem a natureza, a física seria a ciência primeira; se, ao contrário, existe uma substância imóvel, a ciência desta deverá ser anterior e será filosofia primeira" ${ }^{" 12}$. Tendo isso em mente, parece óbvio que o termo "metafísica" nasceu de uma interpretação consciente disso que Aristóteles chama de filosofia primeira, já que o prefixo grego $\mu \varepsilon \tau$ ó (metá) significa "para além". Metafísica: ciência dedicada àquilo que está para além da física, o transcendente.

\footnotetext{
${ }^{9}$ ARISTÓTELES, Metafisica, E 1026a 19.

${ }^{10}$ ARISTÓTELES, Metafisica, E 1026a.

${ }^{11}$ Cf. ARISTÓTELES, Metafisica, B 999b ss.

${ }^{12}$ ARISTÓTELES, Metafisica, E 1026a.
} 
Todavia, "metafísica" não é nenhuma palavra originária. Sua origem remonta à organização dos tratados aristotélicos após sua morte, realizada pelos peripatéticos do Liceu, possivelmente Andrônico de Rodes. Nesta compilação de textos, os livros dedicados à filosofia primeira foram arranjados após os livros

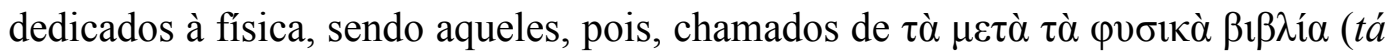
metá tá physiká biblía), ou seja, os livros vindos depois ( $\mu \varepsilon \tau \alpha ́$ ) da física, os livros que se seguem aos livros da física. Ironicamente, a própria origem do termo "metafísica" deve-se a uma questão técnica.

O essencial aqui é que nos coloquemos diante da situação fatal: através desta designação, não se caracteriza a filosofia propriamente dita segundo o conteúdo, segundo sua problemática particular, mas segundo um título que deveria indicar sua posição na ordenação extrínseca dos escritos: $\tau$ ̀̀

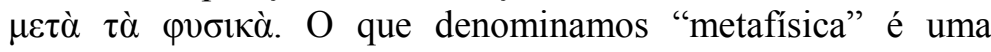
expressão que emerge de uma perplexidade, um termo para um impasse, um termo puramente técnico que, por si só, quanto ao seu conteúdo, ainda não diz absolutamente nada ${ }^{13}$.

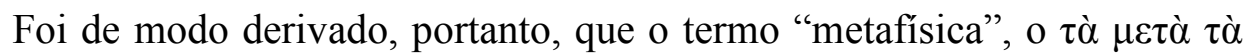

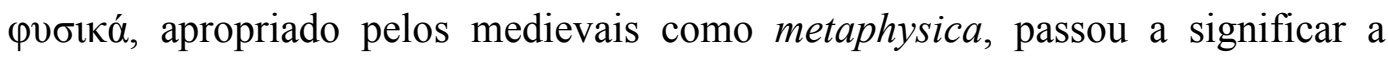
"ciência do transcendente", o estudo da realidade que está para além da realidade física. A compreensão de ser da filosofia, seria, pois - de modo caricatural -, o universal, necessário e transcendente que encontra-se "por detrás" de cada ente particular e dá a ele sua razão de ser. Pelas definições aristotélicas supracitadas, fica claro que a metafísica é, essencialmente, ontologia e teologia, na medida em que busca responder pelo ser dos entes e isso à luz do ente supremo. Em sua essência, a metafísica é onto-teologia. Foi somente por isso que o cristianismo pôde dela se apropriar posteriormente.

Nenhuma das ciências transcende sua região temática. A filosofia, no entanto, seria a lida com o transcendente enquanto tal, o fundamento de todas as demais ciências. Hodiernamente, contudo, não é destinado um grande prestígio à filosofia. As ciências, em especial as ciências da natureza, tomaram para si a validade do saber humano. A filosofia pode ser muito interessante, como erudição, mas não leva a nenhum progresso palpável, e progresso é a "moeda da vez". Se o que a filosofia propõe saber transcende a possibilidade de experimentação, medição e falsificação via controle laboratorial, já que é

\footnotetext{
${ }^{13}$ HEIDEGGER, Os conceitos fundamentais da Metafisica, §11, p. 51.
} 
metafísica, ela fala de coisas que nem sequer existem. Mais uma vez nos deparamos com uma certa compreensão de ser pressuposta: ser é o que existe efetivamente e pode ser medido e experimentado.

Essa perda de vigor e validade da filosofia, enquanto metafísica, já havia sido determinada no interior da própria filosofia. Que Kant tenha, em sua Crítica da razão pura, negado à metafísica o caráter de ciência, foi já um primeiro passo para sua derrocada. Contudo, quem, talvez, tenha abalado de vez seus sustentáculos foi Friedrich Nietzsche. Nietzsche enxergou de forma profética o destino do ocidente, e batizou esse destino de niilismo europeu, a "história dos dois próximos séculos". Ele anuncia: "O niilismo está à porta: de onde nos vem esse mais inquietante (unheimlichste) de todos os hóspedes?"14. O niilismo é inóspito, terrível, perturbador. Ele é unheimlich, estranho. Estranho, unheimlich, diz: estrangeiro, sem lar, desenraizado. Sigmund Freud publicou um texto em 1919 chamado Das Unheimliche ${ }^{15}$, "O Inquietante”. As conotações psicanalíticas do termo dentro do pensamento freudiano não nos interessam aqui de modo algum. Apesar disso, Freud nos oferece uma extensa pesquisa acerca do termo estranheza, Unheimliche. Ele diz:

A palavra alemã unheimlich é evidentemente o oposto de heimlich, heimisch, vertraut [doméstico, autóctone, familiar], sendo natural concluir que algo é assustador justamente por não ser conhecido e familiar. (...) Heimlich (...): pertencente à casa, não estranho, familiar, caro e íntimo, aconchegado. (...) oculto, mantido às escondidas, dissimulado, cf. Geheim [secreto]. (...) Unheimlich: incômodo, que desperta angustiado receio. (...) Nossa atenção é atraída por uma observação de Schelling, que traz algo inteiramente novo. Unheimlich seria tudo o que deveria permanecer em segredo, oculto, mas apareceu ${ }^{16}$.

Heimlich, o antônimo de unheimlich, tem a dupla acepção de familiar e oculto. Essa pesquisa do termo realizada por Freud será de grande importância mais adiante, quando formos tratar do tema da estranheza no pensamento de Heidegger ${ }^{17}$, mas, por enquanto, de modo preliminar, tal descrição já nos é útil para pensarmos com Nietzsche a essência do niilismo. O niilismo, disse Nietzsche, não só é inquietante; ele é o mais inquietante, unheimlichste. Em que sentido podemos entender isso? Que ele é o menos familiar? O mais incômodo? O

\footnotetext{
${ }^{14}$ NIETZSCHE, Vontade de poder, I, p. 27.

${ }^{15}$ Cf. FREUD, Obras completas, vol. 14, pp. 328-376.

${ }^{16}$ FREUD, O Inquietante. In:

${ }^{17}$ Cf. infra, p. 42 ss. . Op. cit., pp. 333-338.
} 
mais angustiante? Ou o que com mais violência põe-se às claras, desoculta-se? Será um desses significados? Algum outro? Todos ao mesmo tempo? Não temos condições de saber isso ainda. Faz-se necessário, antes, compreendermos o que Nietzsche está chamando de niilismo.

Costuma-se associar o niilismo, enquanto recusa de sentido e valor, com uma "decadência", degeneração. Diz-se que os valores se perderam, há uma queda na educação, ninguém mais respeita ninguém, lá se foram os "bons costumes". Essa posição reacionária, facilmente identificável em nossa sociedade, nem mesmo chega a tocar a essência do niilismo. Niilismo, em sentido próprio, que é o que aqui nos importa, é a derrocada da moral, da moral cristã. Essa moral não significa nada de "ético", nem se refere a "costumes". Por "moral cristã" Nietzsche entende platonismo, isto é, metafísica. Já em $O$ nascimento da tragédia, de 1872, obra de juventude de Nietzsche, ele havia visto o essencial:

Agora, junto a esse conhecimento isolado ergue-se por certo, com excesso de honradez, se não de petulância, uma profunda representação ilusória, que veio ao mundo pela primeira vez na pessoa de Sócrates - aquela inabalável fé de que o pensar, pelo fio condutor da causalidade, atinge até os abismos mais profundos do ser e que o pensar está em condições, não só de conhecê-lo, mas inclusive de corrigi-lo ${ }^{18}$.

Entendamos "Sócrates" aqui como uma caricatura", pouco nos importando se Nietzsche faz ou não justiça ao Sócrates histórico ou ao personagem Sócrates dos diálogos platônicos. Sócrates representa, aqui, aquele que primeiro condenou a existência. A existência é penúria, é precária, finita, inconstante, é dor, falta, carência. É como não devia ser. Perante o mundo, o devir, a perene mudança, que traz envelhecimento, debilidade, morte, importa afirmar o eterno e imutável, que transcende, está para além do mundo, o metafísico, como sendo o verdadeiro ser. O mundo verdadeiro é que possui valor.

\footnotetext{
${ }^{18}$ NIETZSCHE, O nascimento da tragédia, $\S 15$, p. 91.

${ }^{19}$ Caricatura entendida conforme a magistral descrição de Bergson: "Por mais regular que seja uma fisionomia, por mais harmoniosas que suponhamos as suas linhas, por mais flexíveis os movimentos, jamais o equilíbrio dela será absolutamente perfeito. Discerniremos sempre a indicação de um cacoete que se insinua, o esboço de uma possível careta, enfim, certa deformação em que se desenhe de preferência a natureza. A arte do caricaturista consiste em captar esse movimento às vezes imperceptível, e em torná-lo visível a todos os olhos mediante ampliação dele. Ele faz com que os seus modelos careteiem como se fossem ao extremo de sua careta. Ele adivinha, sob as harmonias superficiais da forma, as revoltas profundas da matéria. Efetua desproporções e deformações que poderiam existir na natureza se ela pudesse ter vontade, mas que não puderam concretizar-se, reprimidas que foram por uma força melhor. A caricatura, que tem algo de diabólico, ressalta o demônio que venceu o anjo". BERGSON, O riso, p. 17.
} 
Com efeito, o mundo imperfeito do devir deve ser corrigido, e para tal deve conformar-se ao mundo ideal. É a essa correção da existência que Nietzsche faz referência. É a isso que ele chama de moral: ser entendido como dever-ser. "Moral: desembaraçar-se do engano dos sentidos, do vir-a-ser, da história, da mentira" ${ }^{20}$. Moral é tudo aquilo, segundo Nietzsche, de anti-natural. Espiritualizar, isto é, aniquilar, extirpar as paixões. Racionalizar o irracional, a fim de dominá-lo.

Nesse sentido, todos aqueles que crêem nos sentidos são denominados "povo". Sócrates, com sua dialética, expõe a ignorância do "povo" acerca da verdade das coisas, do que está por detrás daquilo que pode ser sentido. Os sentidos associam-se à imoralidade, aos prazeres, ao que se rebela contra a razão. $\mathrm{E}$ a fórmula socrática é clara: razão $=$ conhecimento $=$ virtude $=$ felicidade $\mathrm{O}$ mundo verdadeiro, indemonstrável, é prometido como alcançável ao sábio, virtuoso, penitente, devoto. Mundo verdadeiro como consolo e obrigação, imperativo: impõe-se sua ideia ao "povo", o "povo" deve ser devoto e virtuoso.

O advento do cristianismo e de sua moral é o levar a cabo dessa ideia em escala global. O cristianismo, com Paulo, tornou-se a primeira religião com pretensões universalistas, pois se entende como $a$ verdade, e como tal deve ser disseminada, levada e distribuída como um presente a todas as partes do mundo, a todos os povos. É sob essa ótica que deve ser entendida a famosa passagem de Nietzsche: "o cristianismo é platonismo para o povo",21. Platonismo para o povo quer dizer: imposição do mundo suprassensível, "verdadeiro", como critério e medida para o mundo sensível, "aparente". Mais: condenação dos sentidos, dos prazeres, da dor. Por conseguinte, erra quem lê essa sentença de Nietzsche entendendo povo como "povão", plebe, ralé: é justamente o contrário. "Povo" seria o nobre, o aristocrata. Sócrates seria o plebeu que buscava vingança contra tudo aquilo que era nobre, instintivo. A virtude, a excelência, d’ de ser aquele privilégio do tipo nobre e passa a ser associada ao conhecimento, conhecimento justamente do "verdadeiro", suprassensível.

Durante toda a história da filosofia, essa foi a força criadora do pensamento ocidental. Desse modo, o niilismo nietzscheano não seria apenas afirmar que minhas sensações são o real, ou que a minha vontade define o real, e

\footnotetext{
${ }^{20}$ NIETZSCHE, Crepúsculo dos ídolos, III, §1, p. 25.

${ }^{21}$ NIETZSCHE, Além do bem e do mal, p. 8.
} 
todo o resto é nada. É algo muito mais profundo. Trata-se da história do próprio ente, a história das interpretações da entidade do ente, logo, do ser do ente, legada pela tradição dos pensadores ocidentais. É um processo histórico que definiu as eras do mundo. Essas eras foram pautadas por certos valores, e o que Nietzsche percebeu foi que esses valores haviam se tornado caducos. Não foi ele, Nietzsche, alguém terrível, o destruidor dos valores, destruidor "da moral e bons costumes" da sociedade burguesa de seu tempo, como não poucas vezes se ouve por aí. Ele foi simplesmente um bom médico, cujo aguçado olhar clínico foi capaz de perceber os sintomas que sempre estiveram à vista de todos, mas que ninguém conseguia enxergar, e se deu conta de que aquilo que sempre foi tido como a "saúde" era, na verdade, uma grave "doença". Cabia a ele, pois, o fardo de apresentar tanto o seu diagnóstico quanto o seu prognóstico. Foi a esse chamado que ele atendeu.

Para Nietzsche, niilismo não é uma visão de mundo que irrompe em algum lugar e em algum momento, mas o caráter fundamental do acontecimento no interior da história ocidental. (...) Niilismo significa: os valores supremos se desvalorizam. Isso quer dizer: o que, no interior do cristianismo, da moral desde a Antiguidade tardia, da filosofia desde Platão, foi estabelecido como realidades e leis normativas perde a sua força impositiva, e isso sempre significa para Nietzsche: sua força criadora ${ }^{22}$.

Heidegger vê em Nietzsche a inversão do platonismo, e isso segundo o testemunho do próprio Nietzsche. Inversão do platonismo, no entanto, não é um mero "pôr de cabeça para baixo" as teses platônicas. É isso também, ao menos como um requisito inicial. Para Platão, para o platonismo, grosso modo, o mundo inteligível é o verdadeiro, o mundo sensível é o falso. O inteligível está acima do sensível. A inversão seria afirmar o mundo sensível como o verdadeiro, e o inteligível como o falso, é dizer, pôr o mundo sensível acima do inteligível. Que quer dizer isso, o fato do sensível encontrar-se acima? Significa que agora o sensível é o propriamente ente, ele é o ser verdadeiro. Inverter o platonismo desse modo, no entanto, ou melhor, apenas invertê-lo desse modo, significa ainda jogar o jogo segundo as regras do platonismo, ainda ter como guia os conceitos e as categorias próprias do platonismo, e, com efeito, essencialmente ainda seria platonismo. Isso não passou despercebido por Nietzsche: “Abolimos o mundo

\footnotetext{
${ }^{22}$ HEIDEGGER, Nietzsche, p. 20.
} 
verdadeiro: que mundo restou? O aparente, talvez?... Não! Com o mundo verdadeiro abolimos também o mundo aparente!"23. Para que o platonismo fosse de fato superado, não adiantaria apenas invertê-lo, mas sim erradicar sua própria estrutura de pensamento, arrancá-la pela raiz. Mas iniciar pela inversão significa que um ultrapassamento é necessário. A proposta de Nietzsche teve que partir de dentro, desde dentro, buscar brechas internas, e não olhar de fora, por cima, como um curioso, para dali apontar "inconsistências teóricas".

No entanto, erradicar as bases que sustentavam todo o arcabouço do edifício do pensamento ocidental não seria sua ruína? Não há mais como erigir nada sobre essas bases, pois elas mesmas, no fim das contas, eram nada. A deposição do suprassensível acarreta o sem sentido. Por ter trazido isso à tona, Heidegger afirma que Nietzsche foi o último metafísico. Ele é o último porque é a sua consumação. Depois de Nietzsche, as possibilidades disponíveis para a metafísica foram levadas a cabo, não resta mais modo possível de se fazer metafísica tal como antes, a não ser por má fé. “Os bastidores do teatro do mundo ainda podem permanecer por algum tempo os antigos: o jogo que se transcorre já é um outro" ${ }^{24}$. Nesse sentido, é errado pensar que há, exclusivamente, um juízo de valor negativo quanto ao niilismo. A desvalorização dos valores supremos significa uma libertação, um livrar-se das amarras que sempre serviram de cabresto para o pensamento. A "boa nova" que Nietzsche veio trazer é a possibilidade de, libertos dos valores até então vigentes, conseguirmos nos tornar livres para novos valores. Nietzsche tinha o projeto de uma transvaloração de todos os valores.

Com esse título, "transvaloração de todos os valores", nós tendemos a pensar no fato de valores transformados serem colocados no lugar dos valores até aqui. Para Nietzsche, porém, a "transvaloração" significa: precisamente a "posição" dos valores até aqui desapareceu e não foram apenas eles mesmos que se tornaram caducos ${ }^{25}$.

Heidegger nota que a transvaloração não é simplesmente uma substituição dos valores até então vigentes. Substituir implicaria manter a mesma "posição", o mesmo tópos, o mesmo lugar, qual seja, o "acima" normativo, configurador da essência do platonismo. Seria a repetição do platonismo por

\footnotetext{
${ }^{23}$ NIETZSCHE, Crepúsculo dos ídolos, IV, §6, p. 32.

${ }^{24}$ HEIDEGGER, Nietzsche, p. 483.

25 Idem, ibidem.
} 
outros meios. Esse tópos mesmo, o "acima", o transcendente enquanto razão de ser, é já entendido como valor, como "melhor". Nietzsche, com efeito, pensa pela primeira vez o ser como valor, fazendo com que a própria metafísica passe a ser pensamento valorativo. $O$ transcendente vale mais que o imanente, o suprassensível vale mais que o sensível. Valer mais quer dizer: ter mais ser, mais força. Por conta disso, não bastaria apenas desvalorizar os valores até aqui, mas sim que a sua posição seja desenraizada ${ }^{26}$. Tornar unheimlich a posição fundamental do platonismo.

Nietzsche resume isso em uma breve frase: "Deus está morto". Trata-se de uma afirmação que em certos contextos pode ofender idiossincrasias mais delicadas. A interpretação mais imediata e vulgar, e por isso a mais recorrente e divulgada, é a de que Nietzsche estaria levantando a bandeira do ateísmo e, justamente, já que "Deus morreu”, "tudo é permitido", conforme a já desgastada observação de Ivan Karamázov, no romance Os Irmãos Karamázov, de Dostoiévski, e por isso mesmo deveríamos erradicar os valores da sociedade e vivermos fora da lei, transgredindo todas as normas sociais em prol dos nossos novos valores etc. Indo nessa direção, muitos acreditam contestar ou refutar Nietzsche, mostrando o quanto ele estava errado, já que o número de fiéis em diversas igrejas só cresce, e que a religião continua uma força atuante a ser respeitada na sociedade etc.

Que o homem Friedrich Nietzsche tenha sido ateu ou não, isso é completamente irrelevante. Ele não está expressando suas opiniões pessoais, sua crença ou falta de crença, em seu pensamento. A afirmação "Deus morreu" outra coisa não significa que: os valores supremos perderam seu valor. $\mathrm{O}$ transcendente não é mais a razão de ser do sensível, não é mais a norma e o critério. "Deus", "platonismo" e "metafísica" querem aqui dizer o mesmo, pois a metafísica, enquanto radicalmente platonismo, é onto-teo-logia. Ontoteologia significa: Deus, o sumo ente, a presença constante, o transcendente por excelência, é a matriz e a referência de toda ontologia, isto é, de toda a compreensão de ser, de toda determinação de ser do ente. No famoso aforismo O homem louco, Nietzsche narra que um homem louco, que acendeu uma lanterna em plena manhã, começou a gritar incessantemente que procurava Deus. O vital dessa narrativa é a primeira

\footnotetext{
${ }^{26}$ Idem, ibidem, p. 484.
} 
recepção dos gritos do homem louco: "E como lá se encontrassem muitos daqueles que não criam em Deus, ele despertou com isso uma grande gargalhada" 27 . Os ateus apenas debochavam e ridicularizam o clamor do homem louco. Eles não tinham ouvidos para a mensagem essencial que aquele homem trazia. Nietzsche é explícito: "Deus está morto" é uma mensagem de outra ordem, que nada tem em comum como uma descrença em Deus.

"Deus está morto": os valores supremos até aqui se desvalorizaram. Quais seriam tais valores? São eles a substancialidade, a causalidade e a finalidade. Substancialidade, no sentido de um ser transcendente, "fora" do devir, que sempre é, nunca vem a ser. Ideia de algo imutável em tudo que é que permite e garante o conhecimento; causalidade, causa sui, causa de si mesmo, indemonstrável, mas necessário para interromper uma regressão ao infinito. A partir dessa primeira causa estabelecida, constitui-se um fio condutor como

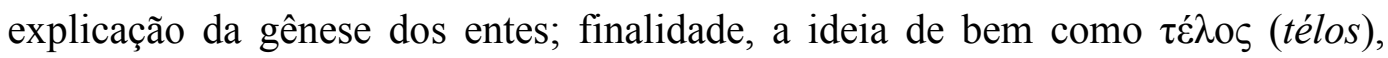
fim, fundamento da deontologia. Toda ação visa um objetivo para além dela própria, um alvo sempre contemplado como "ainda não". Deus é o conceito metafísico que açambarca todos esses valores, e por isso é $o$ valor supremo.

Como o Deus entra na filosofia? A partir da essência da metafísica. (...) A este Deus não pode o homem nem rezar, nem sacrificar. Diante da causa sui, não pode o homem nem cair de joelhos por temor, nem pode, diante deste Deus, tocar música e dançarr ${ }^{28}$.

Esse Deus dos filósofos tem sua existência determinada devido a uma necessidade metafísica. Ele é o primeiro princípio necessário, pois do contrário haveria uma regressão causal ao infinito, Ele é o sumo bem, e por isso fim de toda vontade, é o sumo ente, e por isso presença constante que sustenta e fundamenta os demais entes, é o motor imóvel, e por isso propicia todo o movimento etc. Não há nada de místico nesse Deus. Ele não pertence à dimensão do sagrado, do mistério. Ele é a mera razão humana potencializada, projetada como perfeita e infinita. Esse foi o Deus morto, a sombra que se espraiava por toda a história da metafísica. Nietzsche se refere a esse Deus como sendo o Deus cristão porque esse é o próprio Deus da Escolástica medieval, o Deus que se rebaixa a tal ponto

\footnotetext{
${ }^{27}$ NIETZSCHE, A gaia ciência, §125, p. 147.

${ }^{28}$ HEIDEGGER, Identidade e diferença, pp. 74-75.
} 
que permite demonstrações racionais de sua existência. A "morte de Deus" é também a evidência da decadência do cristianismo institucionalizado.

Voltando ao aforismo acerca do homem louco, este, em seu embate verbal contra os ateus que o ridicularizavam, vocifera aos presentes diversas perguntas, mas uma em particular é de monumental importância: "Não deveríamos nós mesmos nos tornar deuses, para ao menos parecer dignos dele?"29. A “morte de Deus" deixou esse vácuo insuportável. Vimos que Nietzsche exige uma sustentação desse vácuo, que sejamos capazes de suportar a nulidade de todo fundamento. Na realidade, contudo, ocorreu a mera substituição de um valor supremo por outro, mantendo a "posição" de maior valor inalterada. O progresso da história, a fé na ciência, as promessas da tecnologia etc, são alguns dos "novos deuses" que usurparam o lugar do Deus-fundamento. Matamos Deus: não é agora imperativo que nos tornemos deuses? O século XX não foi justamente o testemunho da hiperbolização do sujeito moderno, do seu domínio desmedido? Sujeito moderno aqui não significa esse ou aquele indivíduo. A rigor, até mesmo as sociedades contemporâneas nada mais são do que hipostatizações do sujeito moderno, um "nós" que é mera soma de "eus". Sujeito moderno quer dizer: eu penso. Cogito. Pensar aqui entendido como razão, ratio, e esta como cálculo. Cálculo aqui vai muito além de simples operações matemáticas, não se trata de cálculo stricto sensu. Cálculo é um contar-com. Dizemos "conto com você no jantar dia tal". "Estou contando que não vai chover amanhã". Tácita e irrefletidamente, contamos que o ônibus cumprirá o seu percurso determinado sem acidentes. Contamos que o elevador não vai cair. Contar-com significa certeza, controle, asseguramento e, no limite, assenhoramento. Levando isso em conta, Heidegger comenta o seguinte:

Nietzsche reconhece o instante histórico em que o homem se prepara para entrar na total dominação da Terra. Nietzsche é o primeiro pensador que, considerando a história do mundo tal como esta pela primeira vez nos chega, coloca a pergunta decisiva e a pensa através de toda sua amplitude metafísica. A pergunta é: o homem enquanto homem, em sua constituição de essência até hoje vigente, está preparado para assumir a dominação da Terra? Se não, o que então precisa acontecer com o homem atual, de modo que ele se "submeta" à Terra e assim cumpra a palavra de um velho testamento? Não será preciso

\footnotetext{
${ }^{29}$ NIETZSCHE, A gaia ciência, §125, p. 148.
} 
conduzir o homem atual para além de si mesmo, para poder corresponder a esta missão? $?^{30}$

Sem Deus, ou seja, sem fundamento e sem sentido, o homem incube-se da tarefa de assenhorear-se da Terra, de submetê-la à dominação total, de tornarse, ele próprio, deus. O que está em questão Heidegger já notou: o homem, em seu entendimento de si próprio até então vigente, isto é, animal racional, está à altura desta tarefa? Ou é necessário ultrapassá-lo? Sabemos o que é a humanidade do homem para termos condições de responder e corresponder a tais perguntas? Retornamos, assim, à questão inicial, que abriu o presente capítulo: o que é o homem? Afinal de contas, essa pergunta não era arbitrária. Ora, mas a metafísica, na medida em que se questiona acerca do ente enquanto ente, não estaria apta a responder esta questão, na medida em que o homem é um ente também? Perguntanto pelo ente enquanto tal, ela não vai até mesmo para além do homem, já que faz uma pergunta mais universal? De fato. Mas partir do caráter de ente, é dizer, do caráter ôntico do homem, é insuficiente para a tarefa que aqui se impôs. O questionamento da metafísica lida com o homem de modo apenas incidental.

A pergunta pela essência do humano apresentou-se com um caráter de urgência. Qual seria sua essencialidade radical? O que precederia todas as outras interpretações ônticas já conquistadas na história da metafísica, por exemplo: substância, alma, animal racional, cogito, corpo etc? A pergunta é sobre o ser do homem. Todas essas respostas acima foram consideradas válidas, pois pensou-se o ser a partir do ente. Buscamos aqui o ser enquanto ser, em sua radical “outridade" em relação a qualquer ente. A pergunta pelo ser, no entanto, já sempre pressupõe uma compreensão de ser como ponto de partida. A princípio, questionar o ser em seu sentido próprio não se refere ao homem. Qualquer desdobramento desse questionamento, no entanto, sempre remeterá a alguma compreensão de ser, e isso é próprio do homem. O homem é um ente, tal como a pedra, as plantas e os animais, de fato. Mas apenas o homem põe a pergunta pelo sentido de $\operatorname{ser}^{31}$. Ele é o sítio da questão do ser. E isso porque, seja lá de qual modo for, ele já sempre compreendeu ser. O homem, na medida em que é, compreende e já sempre compreendeu ser de alguma forma. O ser está enraizado no homem. Entendido desse modo, Heidegger expressa o ente que é compreensão

\footnotetext{
${ }^{30}$ HEIDEGGER, Quem é o Zaratustra de Nietzsche? In:

${ }^{31} \mathrm{Cf}$. HEIDEGGER, Ser e tempo, $\$ 2$. . Ensaios e conferências, p. 91.
} 
de ser não como homem, mas como Dasein, ser-aí ${ }^{32}$. Querendo estabelecer a ontologia fundamental, isto é, pôr-se à altura da questão do sentido do ser em sua radicalidade, impôs-se como necessária uma analítica existencial do ser-aí, dada a intrinsecabilidade das questões. É dizer: o ser necessita do homem, ao passo que o homem, reciprocamente, só é homem na medida em que compreende ser.

Essa analítica existencial foi desenvolvida por Heidegger em Ser $e$ tempo, sua obra seminal. Nela, tem-se que a constituição fundamental do ser-aí é ser-no-mundo (In-der-Welt-sein). A princípio, essa asserção nos parece bastante trivial. É óbvio, até para os mais desavisados, que estamos em um mundo. Sempre que uma notícia terrível nos causa grande choque, questionamos "mas que mundo é esse em que vivemos?". É dito de alguém muito distraído que ele estava "no mundo da Lua", havia deixado nosso mundo. Eventos mundiais são aqueles que reúnem diversas nações de vários continentes do planeta. Emissoras de TV afirmam que "o mundo parou" para ver algum acontecimento. Ouvimos falar de descobertas científicas que mudaram o mundo. Várias religiões professam aos que nelas crêem que Deus criou o mundo. Lemos nos livros de história que os navegadores antigos se lançavam aos perigos do oceano desconhecido em direção ao "novo mundo". Nossos cientistas hoje escrutinam o mistério do espaço sideral em busca de "novos mundos" que sejam habitáveis. Os exemplos poderiam prosseguir à exaustão, mas os apresentados bastam para podermos supor que "todo o mundo" sabe que somos em um "mundo", ou, ao menos, que sabemos o que "mundo" significa.

É por isso que uma expressão como "ser-no-mundo" não se nos apresenta como estranha à primeira vista, pois sempre pressupomos que sabemos o que mundo significa. Estamos no mundo, estamos nesse planeta, nesse país, nessa sociedade. Estamos dentro. Fala-se que as fronteiras dos países devem ser protegidas a fim de evitar que imigrantes ilegais entrem em determinado país. A expedição espacial bem sucedida entrou novamente no planeta em seu retorno triunfante, e assim por diante. Nossa tendência, pois, ao nos depararmos com o termo "ser-no-mundo", é a de compreender "mundo" como um recipiente, e, por

${ }^{32}$ É notória a dificuldade de uma tradução suficiente do termo alemão Dasein, adotado por Heidegger para tratar do ente temático capaz de pôr a pergunta pelo sentido do ser. Desse modo, opto aqui pela já famigerada expressão "ser-aí", pois considero-a a menos propícia a causar desentendimentos ou incompreensões. 
conseguinte, falar que somos em um mundo implica que o "mundo" nos contém, somos dentro disto que aqui está se chamando "mundo", tal como o peixe está no aquário (i. e., dentro do aquário) ou o paletó está no armário. Nós, que somos filhos da modernidade, temos dificuldade de não nos pensarmos essencialmente como um "eu", e, consequentemente, como "sujeito", substância, um algo, uma coisa. Nada mais natural, portanto, do que operar essa analogia entre nós e outras coisas que são possíveis conteúdos ante o "mundo" e as demais coisas que são continentes. É isso que, a princípio, quase como que instintivamente, captamos ao ouvir a expressão "ser-no-mundo" como uma de nossas constituições existenciais.

$\mathrm{Na}$ acepção de Heidegger, contudo, mundo não se refere a nada do que foi descrito acima. Não se trata de nada "espacial", no sentido de uma res extensa cartesiana, e, por conseguinte, é incapaz de estabelecer relações espaciais como "dentro" e "fora". Desse modo, também não se trata do globo terrestre, de um planeta, de um conjunto das sociedades humanas. Mundo, escapa, pois, das concepções banais que um tal termo acarreta. Todavia, escapa também de

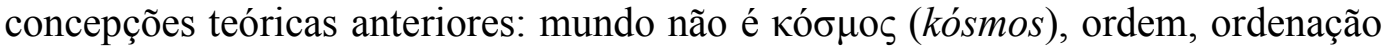
universal em oposição a um caos primordial; tampouco é mundus, termo usado por autores medievais cristãos para designar a totalidade da criação divina, ou mundanus, no sentido de saecularis, o "mundo secular" em oposição ao espiritual; bem como também não é, tal como entendido na modernidade, a totalidade dos entes ou a série de relações dos entes finitos, no sentido de objetividade ${ }^{33}$. Ora, então o que é, para Heidegger, mundo?

Expressamos aqui, retoricamente, uma provável impaciência do leitor. Qual a necessidade de se ficar insistentemente dizendo tudo aquilo que mundo não é, ao invés de ir "direto ao ponto" logo? Não se trata de nenhum suspense, e sim de apontar e ressaltar a dificuldade que é nos desembaraçarmos de nossas préconcepções. Heidegger foi, sabidamente, um grande leitor de Aristóteles. E Aristóteles, em seus Tópicos, define que a natureza da dialética consiste em partir ou de uma opinião sustentada por todos, ou pela maioria, ou pelos sábios ${ }^{34}$. Tais opiniões são por ele denominadas Ěv $\delta o \xi \alpha$ (éndoxa), termo composto por $\delta$ ó $\xi \alpha$ (dóxa), opinião, e a partícula ěv (én), que traduz-se literalmente por nosso "em",

\footnotetext{
${ }^{33} \mathrm{Cf}$. HEIDEGGER, A essência do fundamento, II.

${ }^{34}$ ARISTÓTELES, Tópicos X 104a.
} 
dentro. Com efeito, $\varepsilon^{2} v \delta o \xi \alpha$ nos diz aquelas opiniões - que poderíamos sem pudor chamá-las de pre-conceitos - em que já estamos sempre dentro, imersos. Esses fundamentos das proposições dialéticas, em sentido aristotélico, são conceituados pelo estagirita como тó $\pi$ or (tópoi), os "lugares", no sentido de lugares-comuns, a partir dos quais o diálogo pode se dar e florescer.

Ademais, na Retórica, diz-nos Aristóteles: "Entendo $(\lambda \dot{\varepsilon} \gamma \omega)$ por

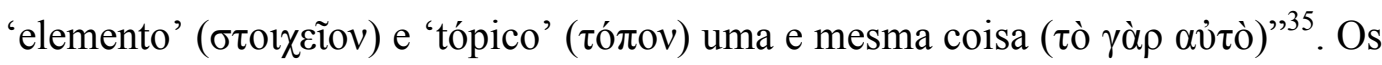
tópicos, por conseguinte, são nosso elemento, nosso medium, aquilo em que já sempre estamos imersos, mesmo sem nos darmos conta. Portanto, pode-se dizer, em certo sentido, que nossos conhecimentos têm como princípio e fundamento os lugares-comuns das opiniões pré-estabelecidas tradicionalmente. Com efeito, Heidegger, nesse sentido aristotélico, parece ser "dialético", ou seja, ele não busca demonstrações lógicas, e sim um certo cuidado de, com esmero, preparar o terreno, removendo as ervas daninhas das opiniões e saberes impensados, cristalizados e passados adiante sem nenhuma cautela. Embora de certo modo nocivas, tais opiniões são necessárias, indispensáveis, e sempre suceder-se-ão, pois estamos já sempre e a cada vez respirando em sua atmosfera. O solo fértil para o manifestar-se dos fenômenos exigirá sempre, destarte, o constante trabalho de destruição (Destruktion) $)^{36}$ de tais opiniões, por mais arraigadas que elas estejam ou pareçam estar.

De certo modo, o que mundo é já está dito. Mundo é um nexo, uma teia de significatividade, um horizonte de sentido. Por não se tratar de uma coisa ou substância, mundo não é nada fechado em uma essência, no sentido da essentia metafísica, ou seja, um universal abstrato que responde a pergunta pelo quid, pelo quê alguma coisa é. Ao contrário, mundo é abertura, abertura de e para possibilidades, é clareira (Lichtung), no sentido daquele locus que irradia luz, e que, portanto, propicia a compreensão dos fenômenos que vêm à luz. Tal abertura para a compreensão dos entes é o nosso "aí". Assim, falar ser-aí e ser-no-mundo diz quase a mesma coisa. Lembremos que ser-aí não é uma substância, de modo que ser-no-mundo não é um predicado que o convém tal como um acidente, não é uma categoria.

\footnotetext{
${ }^{35}$ ARISTÓTELES, Retórica II 1403a.

${ }^{36}$ Cf. HEIDEGGER, Ser e tempo, §6.
} 
Ser e tempo é um tratado que visa responder à questão pelo sentido do ser. Ser-aí é o ente privilegiado capaz de se pôr uma tal questão, privilegiado justamente por já sempre ser no mundo, isto é, já sempre compreende ser de algum modo e já sempre se comportar em relação ao ente de algum modo. Mundo é, em certo sentido, esse “já sempre” da compreensão de ser. Essa compreensão é própria da existência, entendida aqui não como a existentia metafísica, ou seja, efetividade, presença à vista (Vorhandensein) $^{37}$, mas sim como a essência novamente, não enquanto essentia, mas como fenômeno propriamente dito, a gênese ontológica, do ser-aí. É dizer: a essência do ser-aí é a existência, isto é, é ser-no-mundo, é compreender ser, é abertura. Somente afirmar isso, contudo, é ainda um palavrório vazio. Destarte, a estratégia de Heidegger para evitar essas "teorizações" abstratas é partir da cotidianidade mediana como o mundo mais próximo do ser-aí. Este mundo mais próximo do ser-aí é o mundo circundante (Umwelt).

No mundo circundante, os entes intramundanos nos vêm ao encontro. A eles chamamos normalmente de coisas. Estamos, em verdade, em meio a coisas o tempo todo. O mundo circundante é nosso mundo cotidiano, e que traz consigo uma temporalidade própria, que é justamente a temporalidade cotidiana, a flecha do tempo que traduz nossa compreensão ordinária e habitual do que seja o tempo, a saber: houve o passado, estamos no presente, e acontecerá o futuro. Neste exato momento, digito este texto em meu computador, que não é um qualquer, é o meu, que já possuo há anos, que utilizo diariamente, que guarda em sua memória interna memórias minhas também. Este computador está sobre a mesa, que não é qualquer mesa, mas a mesa que veio da casa de meus pais, mesa que já testemunhou ao seu redor várias reuniões de amigos e pessoas queridas. Os entes, as coisas que, no presente, vêm ao meu encontro, são como que cativeiros de lembranças, trazem consigo a memória do passado que já foi. Posso, ademais, projetar um futuro em que essa mesa ou esse computador venham a quebrar, e sejam jogados em um canto, esquecidos ou transformados em sucata ${ }^{38}$. Vivo nessa concepção temporal.

\footnotetext{
${ }^{37}$ Cf. HEIDEGGER, GA 24, p. 20.

${ }^{38}$ Cf. HEIDEGGER, Ontologia (Hermenêutica da faticidade), p. 95 ss.
} 
Essas coisas, todavia, são diferentes de mim. Elas não possuem o modo de ser do ser-aí. Rigorosamente, elas não existem, mas elas são; no entanto, são de outro modo. A lida imediata com as coisas do mundo as revela como possuindo o modo de ser da manualidade (Zuhandenheit), ou seja, elas estão à mão, há uma lida imediata e íntima com essas coisas que surgem ao nosso encontro, não há nenhuma reflexão minha no seu manuseio, nem um conhecimento conceitual, mas sempre já houve uma compreensão prévia de seu ser. Essa compreensão nada tem de psicológico ou subjetivo, ela é um existencial (Existenzial) do ser-aí. O ser-aí já é sempre compreensão de ser, e isso acarreta uma familiaridade com as coisas de nossa lida cotidiana.

Por não ser nada de psicológico ou subjetivo, tem-se que os entes intramundanos não são representações minhas, tampouco são projeções de meu entendimento. As coisas não são objetos que só “existiriam" quando posicionadas em relação a mim, o sujeito. O trabalho hercúleo de Heidegger foi o de romper com essa dicotomia moderna entre sujeito e objeto, res cogitans e res extensa. $\mathrm{O}$ pensamento moderno equiparou a ontologia com a epistemologia, e a questão fundamental passou a ser, se de um lado há o sujeito do conhecimento e de outro o objeto a ser conhecido, como que é possível essa "ponte", o que poderia unir ambos. Para Heidegger, se o modo de ser do ser-aí já é sempre ser-no-mundo, essa questão moderna se revela como um falso problema, pois essa "ponte", essa ligação, já estaria sempre dada, nunca teria havido uma tal separação.

Outra inversão importante operada por Heidegger foi a de ter atribuído à manualidade o caráter originário das coisas, em oposição a toda a tradição que entendia esse caráter como pertencente à subsistência (Vorhandenheit), isto é, a coisa entendida como presença à vista, a existentia no sentido metafísico clássico, ou seja, ente neutro, dotado de categorias, conceitualizável. Tal concepção do ente sempre foi entendida como a mais fundamental, sendo o critério para todas as demais determinações de ser. Heidegger mostra que esse modo de ser não somente não é o mais fundamental e amplo, como também é derivado, i. e., ele depende da manualidade, ele surge da manualidade, quando ocorre uma situação de surpresa (Auffallen) na lida com um instrumento (Zeug). A lida com o manual, que era familiar, às vezes pode sofrer com algum evento inesperado ou fora do comum - como por exemplo a caneta que fica sem tinta quando íamos usá-la para 
escrever -, e é somente neste momento surpreendente que nosso olhar para a coisa passa a ser outro, fazendo com que a manualidade do manual se mostre como tal, o que permite a "teorização" da coisa e, consequentemente, sua determinação como subsistência.

A lida com os entes, seja a partir do modo de ser da manualidade, seja da subsistência, expressa que todo e qualquer comportamento para com os entes se dá no âmbito da compreensão. Como visto, isso, a princípio e provisoriamente, quer dizer que já sempre compreendemos ser de algum modo, há sempre uma compreensão prévia como condição de possibilidade de qualquer lida com as coisas do mundo. Estruturalmente, do ponto de vista da analítica existencial, a compreensão é um dos existenciais do ser-aí que compõem o seu "aí". O outro componente da constituição existencial do "aí" é a disposição de ânimo. O termo que normalmente se traduz por disposição de ânimo, Befindlichkeit, foi cunhado por Heidegger. Há, na língua alemã, a palavra Stimmung, que significa humor. Contudo, esta palavra, por ser de todos conhecida, por ter seu uso desgastado, por já se ter de modo geral uma familiaridade com ela, acarretaria consigo a précompreensão ordinária de que se trata de algo psicológico, do âmbito de uma consciência, de um "eu”, de um sujeito, e não é esse o caso. Heidegger fala do humor, justamente como contraposição ôntica da disposição ${ }^{39}$. A disposição é um existencial, logo deve ser sempre compreendida ontologicamente.

Foi com o intuito de evitar essa má compreensão que Heidegger viu a necessidade de criar o termo Befindlichkeit. Traduzindo-o literal e grosseiramente, o termo significa algo como um "encontrar-se-dade". Diz como que "nos encontramos" no mundo, de que modo estamos no mundo. Por não ser nada de psicológico ou egóico, não se trata aqui de um sentimento. Nós não temos uma certa disposição de ânimo; antes, é ela que nos tem. A disposição nos toma, nos arrebata, e isso influencia nossa lida com os entes intramundanos, i. e., o modo com o qual lidamos com as coisas em nossa cotidianidade. A disposição sintoniza-nos com as coisas. Heidegger diz: ela nos abre o mundo.

O mundo que já se abriu deixa e faz com que o ente intramundano venha ao encontro. Essa abertura prévia do mundo, que pertence ao ser-em, também se constitui de disposição. Deixar e fazer vir ao encontro é, primariamente,

\footnotetext{
${ }^{39}$ Cf. HEIDEGGER, Ser e tempo, $\$ 30$.
} 
uma circunvisão e não simplesmente sensação ou observação. Numa ocupação dotada de circunvisão, deixar e fazer vir ao encontro tem o caráter de ser atingido, como agora se pode ver mais agudamente a partir da disposição ${ }^{40}$.

A abertura do mundo implica em uma abertura para as coisas. Aberto aqui diz: receptivo, apto a ser tocado. Nosso agir no mundo, nossas relações, nosso comportamento para com as coisas, tudo é sempre condicionado por algum $\pi a ́ \theta$ os (páthos). Nesse sentido, nosso ser-no-mundo é sempre patológico, não no sentido de estarmos doentes, e sim pelo fato de nosso aí, a facticidade em que já sempre nos encontramos, ser estruturada - por falta de melhor expressão $-a$

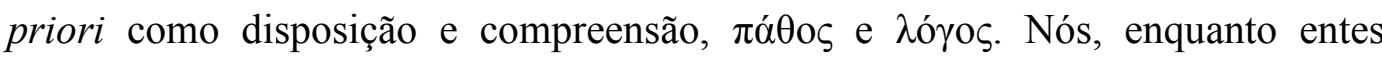
dotados de ser-aí, de existência, somos o nosso aí. Mas não o somos como se nosso aí fosse uma projeção de nosso entendimento enquanto sujeito puro do conhecimento, pois vimos que não é este o caso, mas sim como projeção de nossas possibilidades existenciais, o que é bem diferente. Dito de outro modo: nosso aí, a facticidade que nos constitui, projeta nossa rede, nossa teia de possibilidades de ser. Sendo nosso aí, somos esse projeto, somos responsáveis por nossa existência e o que dela acarretará. Essa teia de possibilidades não é nada de fechado; é, ao contrário, a própria abertura. Contudo, mesmo sendo abertura, ela é finita. Isso evidencia o fato de que estamos lançados no mundo, jogados na existência.

A compreensão de que estamos lançados no mundo não equivale a nosso nascimento biológico, mas sim a uma espécie de despertar, propiciada pela disposição. A disposição, desse modo, ao mesmo tempo em que nos abre o mundo de determinado modo, nos desvela o fato de estarmos lançados no mundo. A expressão utilizada por Heidegger para mostrar nosso caráter de lançados no mundo é Geworfenheit. Geworfen é o particípio passado do verbo werfen, lançar, atirar, donde Geworfenheit nos daria uma tosca tradução literal de "ter-sidolançado-dade". O que não pode passar despercebido é que o verbo werfen tem um parentesco com o substantivo Wurf, que significaria algo como jogado, deixado de lado. O importante aqui é que o termo que traduzimos por projeto é Entwurf, cujo prefixo ent- denota o caráter de remoção, privação, negação. Com efeito, o projeto é quando se nega nosso puro caráter de lançado, e possibilidades existenciais são

\footnotetext{
${ }^{40}$ HEIDEGGER, Ser e tempo, $\$ 29$, p. 196.
} 
sacrificadas em detrimento de outras. Jogados no mundo, temos todo um leque aberto de possibilidades existenciais, mas elas nada dizem por si mesmas se não assumirmos a responsabilidade de cuidarmos de nosso próprio ser, de não projetarmos nossa existência. "Enquanto ente entregue à responsabilidade de seu ser, ele também se entrega à responsabilidade de já se ter sempre encontrado encontro que não é tanto fruto de uma procura direta mas de uma fuga"41.

Esse já se ter sempre encontrado (befinden) significa que já sempre estamos dispostos de certo modo, como se viu acima. Mas o adendo de Heidegger é crucial: encontramo-nos não como se procurássemos a nós mesmos, como se buscássemos alguma espécie de autoconhecimento, alguma instrospecção ou algo do tipo. Dá-se o inverso: já sempre encontramo-nos no mundo porque fugimos, fugimos de nós mesmos, fugimos da responsabilidade de assumirmos nosso projeto, fugimos da lida com nosso próprio ser. Nosso refúgio é nosso mundo circundante, a cotidianidade, o hábito, a rotina, a familiaridade. Por conseguinte, sempre que, de súbito, encontramo-nos no mundo deste ou daquele modo, comportando-nos em relação às coisas desta ou daquela maneira, estamos já fugindo de nós próprios. A questão que se apresenta aqui é particularmente espinhosa, pois reiteradamente afirmamos que o ser-aí não é um “eu”, uma consciência subjetiva, e agora impõe-se um cuidar de si próprio, ser responsável por seu próprio ser enquanto projeto existencial. Há uma passagem do Zaratustra, de Nietzsche, que pode nos ajudar a elucidar essa matéria:

\footnotetext{
"Eu", dizes tu, e tens orgulho dessa palavra. A coisa maior, porém, em que não queres crer - é teu corpo e sua grande razão: essa não diz $\mathrm{Eu}$, mas faz Eu. (...) O Si-mesmo sempre escuta e procura: compara, submete, conquista, destrói. Domina e é também o dominador do Eu. Por trás dos teus pensamentos e sentimentos, irmão, há um poderoso soberano, um sábio desconhecido - ele se chama Si-mesmo. Em teu corpo habita ele, teu corpo é ele. (...) Ainda em vossa tolice e desprezo, vós, desprezadores do corpo, atendeis ao vosso Si-mesmo. Eu vos digo: vosso próprio Si-mesmo quer morrer e se afasta da vida. Já não é capaz de fazer o que mais deseja: - criar para além de si. Isso é o que mais deseja, isso é todo o seu fervor. (...) Vosso Si-mesmo quer perecer, e por isso vos tornastes desprezadores do corpo! Pois não mais sois capazes de criar para além de vós ${ }^{42}$.
}

\footnotetext{
${ }^{41}$ HEIDEGGER, Ser e tempo, §29, p. 194.

${ }^{42}$ NIETZSCHE, "Dos desprezadores do corpo", Assim falou Zaratustra, I, pp. 35-36.
} 
A princípio, Nietzsche parece indicar que esse si-mesmo, ou si-próprio, é algo como o inconsciente, que espreita e sub-repticiamente determina a consciência. Não é esse o caso na passagem acima, nem tampouco o é no pensamento de Heidegger, pois tal teria como pressuposto uma estrutura de subjetividade que seria contrária a tudo que se disse até aqui. O si-próprio (Das Selbst) não é um “eu”, mas cria um "eu”. Não é, pois, nada da ordem do egóico previamente dado que é o fundamental. Alcançar esse si-próprio nada mais é que dar voz ao paradoxo de Píndaro: "torna-te quem tu és". O "eu" nunca já é, mas sempre se faz, sendo portanto epigonal, derivado. O paradoxo é justamente esse: quando lidamos com nosso "eu”, estamos fugindo de nós-próprios. O nosso "eu" é quem age no mundo cotidiano, nosso "corpo", aquilo que apresentamos de empírico. O ser-aí mesmo, como tal, "puro”, não se dá, não se deu, nem nunca se dará efetivamente. "Ser-aí - o ser que distingue o homem em sua possibilidade; (...) o que ao mesmo tempo sub-funda e ultrapassa o homem"43. Nosso ser-aí é a transcendência de nosso "eu" cotidiano ao mesmo tempo em que é seu fundamento. Plotino expressa isso com uma beleza extraordinária:

Porque em todas as circunstâncias da vida real, não é a alma dentro de nós, mas sua sombra, o homem exterior, que geme, se lamenta e desempenha todos os papéis neste teatro de palcos múltiplos, que é a terra inteira. (...) Seu ato é, pois, um ato de artista, comparável ao movimento do dançarino; o dançarino é a imagem desta vida, que procede com arte; a arte da dança dirige seus movimentos; a vida age semelhantemente com os viventes ${ }^{44}$.

Refugiamo-nos no teatro da vida que é o mundo cotidiano porque ele se apresenta como nosso lar. Neste teatro, todos têm o seu papel, o seu script, e é confortável ter apenas de seguí-lo. Difícil, árduo, é escrevermos nosso próprio roteiro. De fato. Mas o palco não se mostra enquanto palco na maior parte do tempo, assim como seria absurdo ao prisioneiro da Alegoria da Caverna, de Platão, que nunca saiu da caverna e passou a vida a contemplar o desfile de sombras projetadas na parede, ter consciência de que ele estava em uma caverna percebendo sombras. Para quem passou a vida toda encenando fielmente seu papel no palco da vida, este palco é a medida, o padrão, o critério. Por isso que o prisioneiro liberto que retorna à caverna é tido como louco para os que dela nunca

\footnotetext{
${ }^{43}$ HEIDEGGER, Contribuições à filosofia, §176, p. 293.

${ }^{44}$ PLOTINO, Enéadas, III apud ROSA, Noites do Sertão, p. 6.
} 
escaparam. A homologia é inconcebível. E talvez devamos advogar a favor dessa loucura, pois seria ela que nos capacitaria a realizar aquele salto necessário da autenticidade. Platão nos diz, no Fedro, que "há dois gêneros de loucura: a produzida por doenças humanas e a que por uma revulsão divina nos tira dos hábitos cotidianos"45. O que seria essa loucura divina, que sacode nossos pressupostos cotidianos?

No contexto de Ser e tempo, sem dúvida essa loucura seria o que Heidegger deu o nome de angústia (Angst). A angústia, segundo Heidegger, é uma disposição de ânimo, mas não uma disposição qualquer: trata-se de uma disposição fundamental do ser-aí (Grundbefindlichkeit). Normalmente, quando ouvimos falar de angústia, temos em mente a ansiedade, a síndrome do pânico, o medo. Tudo isso são humores, patologias, da ordem do ôntico em geral. A angústia, sendo uma disposição e, portanto, de ordem ontológico-existencial, não deve ser confundida com nada disso. Não nos angustiamos com coisa alguma, i. e., nenhum ente intramundano é capaz de nos causar angústia. A angústia se dá. Arrebata-nos sem aviso prévio. Gratuitamente, ou seja, sem por quê nem para quê. Quando, e se, a angústia irrompe, sentimo-nos estranhos (unheimlich).

Isso significa que a angústia é uma disposição de outra ordem, e por isso Heidegger a caracteriza como fundamental. Imersos na angústia, o mundo não se abre de certo modo: ele se abre como tal; não nos encontramos dispostos de certo modo: a decadência, o fato de estarmos lançados, se apresenta como tal. Precisamente por isso nos sentimos estranhos. Un-heimlich: fora de nosso lar, "estrangeiro". Nosso lar era precisamente a cotidianidade mediana. Sentíamo-nos em casa sob sua égide, sentíamo-nos em casa representando nossos papeis no palco da vida pública. A angústia nos tira o chão, nos deixa sem o solo firme, metáfora para nossa segurança, conforto. As sombras que eu e todos próximos a mim víamos refletidas na parede da caverna eram toda a verdade, toda a realidade. Disputávamos sobre o que elas representavam, significavam, mas não sobre o seu estatuto ontológico. O hábito e a rotina fizeram das sombras toda a verdade, e essa certeza trazia consigo uma maravilhosa sensação de segurança. Mas o terrível desagrilhoar da angústia nos permite virar a cabeça pela primeira vez, e daí seguese a dor. Dor dos olhos que, acostumados com as trevas, voltam-se para as chamas

\footnotetext{
${ }^{45}$ PLATÃO, Fedro, 265a.
} 
responsáveis pelo projetar das sombras. Dor do esforço exigido pela subida íngreme que conduz para fora da caverna. A estranheza é essa dor. A responsabilidade, o cuidado pelo nosso próprio ser é essa dor. Por isso nosso primeiro instinto é voltar para o aprisionamento, voltar para o conforto mecanizado da publicidade, das respostas prontas, previamente estabelecidas, cuja repetição encontra aprovação, concordância entre nossos pares. Descartes dá o testemunho disso:

Mas esse desígnio é árduo e trabalhoso e certa preguiça arrastame insensivelmente para o ritmo de minha vida ordinária. E, assim como um escravo que gozava de uma liberdade imaginária, quando começa a suspeitar de que sua liberdade é apenas um sonho, teme ser despertado e conspira com essas ilusões agradáveis para ser mais longamente enganado, eu reincido insensivelmente por mim mesmo em minhas antigas opiniões e evito despertar dessa sonolência $[\ldots]^{46}$.

No entanto, havendo a angústia imperado, sabemos que entregar-se a isso seria viver uma farsa. Algo no fundo de nosso ser clama que deixemos de viver nessa ilusão. Experimentamos o despertar, e fechar os olhos forçadamente não será capaz de anular essa experiência, pois não há como fingir que ela nunca aconteceu. Angustiados, é imperativo que cessemos a fuga de nós mesmos. A familiaridade com as coisas se dissolve. Com a estranheza, o próprio mundo torna-se estranho a nós. Tudo a nossa volta parece se dissolver. É aí que torna-se possível transcender nosso mundo circundante para termos acesso ao mundo enquanto tal. $\mathrm{O}$ mundo circundante é nosso mundo imediato, nossa facticidade, a cotidianidade mediana onde se desenrola nossa vida. O mundo como tal está para o mundo circundante assim como o ser-aí está para nosso "eu": é o ontológico velado que transcende nossa experiência imediata, mas que é a razão de ser desta. Justamente por isso, o mundo como tal mostra-se como sendo nada, pois não é coisa alguma, ente algum. A reboque, e pelo mesmo motivo, fica claro que nosso ser-aí é também nada. Se somos nada em meio ao nada, impõe-se a questão aterradora: o que é o nada?

No nosso interrogar já pressupomos antecipadamente o nada como algo que "é" de tal e tal modo - como um ente. É dele precisamente, porém, que o nada se distingue pura e simplesmente. (...) Se for assim, também toda resposta a esta

\footnotetext{
${ }^{46}$ DESCARTES, Meditações metafisicicas, Primeira Meditação, p. 89.
} 
questão é, desde o início, impossível. Pois ela se desenvolve necessariamente sob esta forma: o nada "é" isto ou aquilo ${ }^{47}$.

Questionar o nada contraria toda a lógica que baseia nossos raciocínios, pois a questão obriga o nada a objetificar-se, o que é um evidente contrassenso, já que o nada nada é. Mas será que quando Heidegger tematiza o nada, ele o faz dentro do escopo da lógica? Que estamos chamando aqui de lógica? Mostra-se imperativo elaborarmos estes questionamentos antes de adentrarmos no vertiginoso e abissal nada. Em sua Carta sobre o humanismo, Heidegger nos oferece uma preciosa pista quanto à essência da lógica que aqui tomaremos como nosso ponto de partida neste tema. Ele, em meio à sua crítica ao humanismo, fala dos mal-entendidos inevitáveis das interpretações de Ser e tempo, mal-entendidos estes onde todos apresentam a "mesma estrutura e a mesma base"48, a saber: “interpretar naturalmente o que se leu ou o que apenas se repetiu, fazendo com que coincida com a opinião que já se imaginava ter antes da leitura"49. O vital desta passagem é o "naturalmente", pois é aí que Heidegger enxerga a raiz dos mal-entendidos em questão, qual seja, o ponto, o âmbito de onde e desde onde tais interpretações surgem e medram: o senso comum, o saudável entendimento humano, nossa "luz natural". Partimos de nossas pressuposições, que por definição são inquestionadas, impensadas, e as tomamos como o critério e a medida da interpretação e compreensão da obra. A interpretação já parte de um saber, um "já sei mais ou menos o que o autor quer dizer com isso", que bate o martelo da decisão hermenêutica, que já nos fecha para qualquer possibilidade de espanto, assombro. Quando partimos tendo como medida nossas pré-concepções, o interpretado tem que adequar-se a elas, e, consequentemente, o fim será uma equalização, pois o que há de novo não se encaixa e deve sofrer a moléstia da correção forçada. Partindo do senso comum, a hermenêutica nada mais é que um "Leito de Procusto". E Heidegger parece identificar o senso comum com a lógica, como atesta a seguir, nesta longa mas importante passagem:

Então, visto que se fala contra o "humanismo", teme-se estar defendendo o des-humano e uma valorização da brutalidade bárbara. Pois o que é mais "lógico" do que isto: para quem nega o humanismo, o que lhe resta senão a desumanidade? E visto que isto se contrapõe à "lógica", imagina-se que se esteja exigindo a negação do rigor do pensar, instituindo, em lugar

\footnotetext{
${ }^{47}$ HEIDEGGER, O que é metafisica. In: . Marcas do caminho, p. 117.

${ }^{48}$ HEIDEGGER, Carta sobre o humanismo. In:

${ }^{49}$ Idem, ibidem. . Marcas do caminho, p. 359.
} 
desse, a arbitrariedade dos instintos e sentimentos e, assim, proclamando o "irracionalismo" como verdadeiro. Pois o que há de mais "lógico" do que isto: quem é contra a lógica defende o a-lógico? Como isto se contrapõe igualmente aos "valores", fica-se estarrecido diante de uma filosofia que supostamente ousa legar ao desprezo os mais elevados bens da humanidade. Pois o que há de mais "lógico" do que isto: um pensar que nega os valores deve obrigatoriamente desprezar tudo como insignificante? Como se disse que o ser do homem consiste no "ser-no-mundo", acha-se que o homem foi rebaixado ao nível de um ser que está só no aquém, o que faz com que a filosofia acabe decaindo em um positivismo. Pois o que é mais "lógico" do que isto: quem afirma a mundanidade do ser do homem está confirmando a validade apenas do aquém, negando todo além e rejeitando toda "transcendência"? Visto que se faz referência à sentença nietzscheana sobre a "morte de Deus", uma tal ação é declarada como ateísmo. Pois o que há de mais "lógico" do que dizer que aquele que fez a experiência da "morte de Deus" seja um a-teu, um sem-Deus? Como em tudo que se mencionou se fala em geral contra o que a humanidade considera como elevado e santo, esta filosofia ensina um "niilismo" irresponsável e destrutivo. Pois o que há de mais "lógico" do que afirmar que aquele que, por toda parte, nega deste modo o que é verdadeiramente o ente, se coloque ao lado do não-ente, predicando, assim, o mero nada como o sentido da realidade $?^{50}$

Desse modo, a lógica, ao menos preliminarmente, tem um caráter excludente essencial. Ela opera com a díade, com pares opostos, onde a posição de um dos "lados" exclui a possibilidade de ser do outro. Se é bom, não é mau, e vice-versa, e assim por diante: se é frio, não é quente; se é belo, não é feio etc. A patência dessas asserções impõe-se independentemente de nossa vontade. Qualquer indivíduo, só por estar no mundo, empiricamente as apreende, mesmo que "inconscientemente": per se notum omnibus, é manifesto por si mesmo para todos. Tamanha clareza e precisão garantem, a reboque, universalidade, logo, abstração. A lógica formal é edificada de tal modo que nenhum ser humano, de parte alguma do planeta, seja um professor europeu, um aborígene, um esquimó ou o padeiro da esquina, seria capaz, tendo-a compreendido, de refutá-la. Quando Sócrates, no Mênon, auxilia o escravo da personagem que nomeia o diálogo, que nunca havia sido formalmente educado, a demonstrar o teorema de Pitágoras, como uma exemplificação da hipótese da reminiscência ${ }^{51}$, podemos, escusandonos de uma interpretação de uma possível teoria da reminiscência na filosofia platônica, interpretar ali, kantianamente, que há uma certa estrutura a priori

\footnotetext{
${ }^{50}$ HEIDEGGER, Carta sobre o humanismo. In:

${ }^{51}$ PLATÃO, Mênon, 82-85. . Marcas do caminho, pp. 359-360.
} 
comum da mente humana, leis universais da razão. Aristóteles explicíta-as na Metafisicica $^{52}$, como os primeiros princípios do ser. Se, ainda em nossa hipótese de pressupostos kantianos, compreendermos que ser é posicionalidade ${ }^{53}$, isto é, o modo como o objeto é posto em relação ao sujeito do conhecimento, podemos, para além de Platão e Aristóteles ${ }^{54}$, afirmar que esses primeiros princípios são subjetivos, no sentido da subjetividade transcendental. Daí sua universalidade, pois todo ser racional é obrigado a concordar com estes princípios para poder conhecer qualquer coisa que seja.

E quais seriam esses primeiros princípios? Tradicionalmente, Aristóteles explicitou três princípios, a saber: (1) o princípio de identidade; (2) o de nãocontradição; e (3) o do terceiro excluído. O princípio de identidade diz que $\mathrm{A}=\mathrm{A}$, isto é, todo ente é igual a si próprio. Com base nisso, tem-se o princípio de nãocontradição, que diz que nenhum ente pode ser e não ser ao mesmo tempo e sob o mesmo aspecto. Por fim, o princípio do terceiro excluído diz que entre o ser e o não ser não há meio termo, ou seja, ou algo é ou não é. Podemos somar a estes três princípios clássicos um quarto princípio, explicitado por Leibniz: o princípio de razão suficiente, que diz que tudo que é tem uma razão de ser, não há nada que seja sem uma causa. Estes são os primeiros princípios porque estão sempre pressupostos em qualquer operação racional. Até mesmo para tentarmos refutá-los teríamos que nos valer destes princípios, o que impossibilita a própria refutação. Estes princípios são o fundamento da lógica. Respeitá-los é o que propicia a "saúde" do entendimento humano. Afrontá-los é loucura, irracionalidade, de acordo com estes mesmos princípios.

A lógica, como dissemos, é o senso comum, o universal, uniforme, abstrato, puro. Ela dirige nossa atitude natural para com o mundo. Justamente por ser universal, comum, ela estabelece o padrão da obviedade. Obviedade aqui diz a lassidão, o sono, o marasmo, a letargia, a preguiça, a fuga. O que é óbvio nunca é questionado, pois já é sabido. Todos os interlocutores dos diálogos socráticos,

\footnotetext{
${ }_{52}^{52}$ Cf. ARISTÓTELES, Metafisica, $\Gamma 3$ 1005a ss.

53 "Ser não é, evidentemente, um predicado real, isto é, um conceito de algo que possa acrescentarse ao conceito de uma coisa; é apenas a posição de uma coisa ou de certas determinações em si mesmas. No uso lógico é simplesmente a cópula de um juízo" KANT, Crítica da razão pura, A598/B626. Cf. HEIDEGGER, A tese de Kant sobre o ser.

${ }^{54}$ Seria longa a discussão se Platão e Aristóteles eram "realistas" e, portanto, estes primeiros princípios do ser seriam "objetivos", predicados da própria realidade. No entanto, embora bastante rica, não é essa discussão a que aqui nos interessa.
} 
aqueles tidos como os que Platão escreveu em sua juventude e que mais se aproximariam do Sócrates histórico, todos eles nos mostram o choque que Sócrates causa com seu exame filosófico. Pois o exame socrático perturba a obviedade sonolenta. Nada mais natural, por exemplo, para o general Laques saber o que seja a coragem, pois ele a testemunhara diversas vezes nas batalhas, o que seja a coragem é, para ele, óbvio. Mas quando questionado por Sócrates, ele não sabe definí-la. Em seu íntimo, Laques sabe que sabe, mas é incapaz de traduzir tal saber em palavras. A posição de Sócrates é a de saber que não sabe, e isto se mostra como o princípio do conhecimento. Enquanto estivermos assegurados das coisas, no conforto familiar de sua existência de tal ou tal modo, permaneceremos mergulhados no impensado. A surpresa do manual que, de uma hora para outra, deixa de exercer sua função, é já um rompimento da obviedade que era o funcionamento daquele instrumento. $\mathrm{O}$ óbvio traz consigo essa mecanização, esse automatismo, essa rotina, esse hábito. Óbvio, ob-vius: aquilo que encontra-se no caminho, que opõe-se à via. Podemos dizer: que bloqueia, atravanca o método. Nosso método, nosso caminho aqui é a fenomenologia enquanto ontologia, "ciência do ser" ${ }^{\text {" }}$, e o óbvio, as coisas e nossa lida cotidiana com elas, é o que vai contra esse caminho, na medida em que esconde o ser das coisas, oferecendo apenas o ente enquanto tal.

A inquestionabilidade, o caráter indubitável do ente manifesto, da coisa presente à vista, é o refúgio do bom senso contra a filosofia. Todavia, o senso comum humano tem sua razão de ser, tem sua necessidade. Seria uma grande tolice qualquer pretensão de erradicação do senso comum para advogar a importância da "filosofia" ou do "pensamento crítico". A cotidianidade é estrutural, pois nosso ser-aí, enquanto ser-no-mundo, é já sempre jogado no mundo, decadente. O problema que Heidegger percebe, e que acarreta consigo enorme perigo, é o de que, na era da técnica, a decadência tornou-se cadência absolutamente. A ciência, o cientificismo, enquanto logicismo e, portanto, o senso comum potencializado, impera e vige soberanamente. O "pensamento" tecnocientífico é o único aceito, válido, importante. É o único padrão, paradigma, medida, a pedra de toque absoluta da verdade e, portanto, da realidade. Curiosamente, Heidegger, em sua preleção Sobre a essência da verdade, chama a

\footnotetext{
${ }^{55}$ Cf. HEIDEGGER, Ser e tempo, §7.
} 
essa dominação expressa do senso comum de sofística ${ }^{56}$. A sofística, enquanto determinação essencial do senso comum, é o "outro lado da moeda" da filosofia. É a "aparência" da filosofia. E, na era da técnica, o domínio pertence à sofística. Vemos hoje que a filosofia tem se tornado um mero saber geral e genérico, uma mercadoria de erudição de "alta cultura", um interesse e passatempo, mas que nada tem a dizer sobre a verdade e a realidade, porque determiná-las é hoje papel da ciência. A filosofia só teria utilidade enquanto lógica, analítica, por poder ser, assim, instrumento, ferramenta da ciência. Qualquer pretensão para além disso acaba virando curiosidade, fantasia, visão de mundo, misticismo. Pois a lógica, como visto, é essencialmente excludente. Se não é ciência, logo não é saber que presta. Se não pode ser mensurado, logo não é real. Ou-ou. Um ou outro, necessariamente.

Entretanto, no que diz respeito a esta discussão, Platão nos dá a pensar. No Banquete, Sócrates narra em seu discurso sobre Eros a doutrina que havia ouvido de Diotima de Mantinéia. Segundo Sócrates, ela foi a responsável por

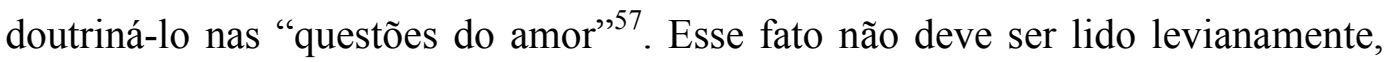
pois anteriormente neste mesmo diálogo afirmou Sócrates que ele de nada mais

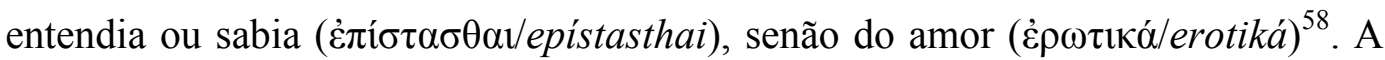
afirmação é chocante, pois Sócrates nunca hesita em nos lembrar nos demais diálogos de que ele nada sabe, e agora ele assevera conhecer as questões do amor, amor erótico. Enfim, Diotima teria demonstrado a Sócrates, dialeticamente, que Eros não podia ser nem belo nem bom ${ }^{59}$. Ao que Sócrates rebate, escandalizado:

Como assim, Diotima! Nesse caso, Eros é feio e mau?

E ela: Não blasfemes! Pensas, porventura, que o que não é belo terá de ser necessariamente feio?

- Sem dúvida.

E quem não for sábio, será ignorante? Não percebeste que há algo intermediário entre a sabedoria e a ignorância?

- Que poderá ser?

A opinião verdadeira de alguma coisa, sem que se possa justificá-la. Como bem sabes, continuou, nem é conhecimento pois como poderá haver conhecimento do que não se pode demonstrar? - nem ignorância, visto não poder ser ignorância o que atinge, de algum modo, o real. A opinião verdadeira é qualquer coisa desse tipo, entre a compreensão e a ignorância.

\footnotetext{
${ }^{56}$ HEIDEGGER, A essência da verdade. In:

${ }^{57}$ PLATÃO, Banquete, $201 \mathrm{~d}$.

${ }^{58}$ Idem, ibidem, $177 \mathrm{~d}$.

${ }^{59}$ Cf. PLATÃO, Banquete, 199c ss. Marcas do caminho, p. 211.
} 
- Tens razão, lhe disse.

Não obrigues, por conseguinte, a ser feio o que não é belo, nem a ser ruim o que não for bom. É o que se dá com Eros: uma vez que tu mesmo admitiste não ser ele nem belo nem bom, não te ponhas a imaginar que ele seja feio e mau, porém algo, arrematou, entre esses dois extremos ${ }^{60}$.

Sócrates iniciou a conversa partindo do senso comum, do binarismo excludente da lógica. Diotima o estarrece com a introdução de um elemento essencial: o entre. Diante da lógica do ou-ou, Diotima afirma o hífen. Esta capacidade de enxergar o meio termo, pensando agora com Aristóteles, não é justamente o que caracteriza o sábio, o virtuoso, o nobre? Guimarães Rosa nos dá testemunho disso com brilhantismo: "Um gênio é um homem que não sabe pensar com lógica, mas apenas com a prudência. A lógica é a prudência convertida em ciência; por isso não serve para nada"61. Prudência, aqui, diz $\varphi \rho o ́ v \eta \sigma 1 \varsigma$ (phrónesis), a grande virtude da sabedoria prática, que determina o justo meio e, consequentemente, manifesta as virtudes éticas. Dizer que a virtude, enquanto meio termo entre dois vícios, é o justo meio, nada tem de casual. A nobreza do sábio deve-se justamente a esta justiça interna, a este senso de justiça que ele carrega consigo em todas as decisões da vida. Justiça significa, segundo Simônedes, dar a cada um o que lhe é devido. "Dai, pois, a César o que é de César, e a Deus o que é de Deus" ${ }^{\text {62 }}$. Assim, a verdadeira virtude, o justo meio, não é alcançável por meio de um cálculo. Não existe uma tabela para isso, não se trata de algo que possa ser universalizado. A medida não é "objetiva". Aristóteles é categórico nesse sentido:

Por exemplo: se dez é demais e dois é pouco, seis é o meio termo, considerado em relação ao objeto, porque este meio termo excede e é excedido por uma quantidade igual; esse número é intermediário de acordo com uma proporção aritmética. Mas o meio termo em relação a nós não deve ser considerado dessa forma; se dez minas de alimento é demais para uma determinada pessoa comer e duas minas é muito pouco, não se segue necessariamente que o treinador prescreverá seis minas; porque isso talvez também seja demasiado para a pessoa que deve comê-lo, ou então pode ser muito pouco - muito pouco para Milo e demais para um atleta principiante $^{63}$.

\footnotetext{
${ }^{60}$ PLATÃO, Banquete, 201d-202b.

${ }^{61}$ Cf. LORENZ, Diálogo com a América Latina. Entrevista com Guimarães Rosa.

${ }^{62}$ Mt. 22:21.

${ }^{63}$ ARISTÓTELES, Ética a Nicômaco, II 1106a-b.
} 
No entanto, nos dias de hoje, onde a tecnociência é a norma e a medida e se espraia como método em todos os âmbitos da vida, o "meio termo que define a virtude" tornou-se cálculo, e o grande exemplo disso é a medicina, que tem tido, a cada vez mais, a pretensão de ser uma ciência exata, uniformizando as prescrições para todos os pacientes. A tendência é transformar a prudência em ciência, a justiça em cálculo. O gênio não pensa com lógica, pensa com prudência.

Estas longas considerações que nos desviaram momentaneamente da questão da angústia tiveram como objetivo assegurar, sem deixar nenhuma sombra de dúvida, de que o sentido de nada derivado do senso comum não é o mesmo utilizado por Heidegger. O nada, na acepção do senso comum, é o não ente, negação de existência, e, portanto, inútil, pois é incapaz de fornecer algum conhecimento, já que não é objetificável e, consequentemente, mensurável. Já o nada, para Heidegger, é uma experiência. Experiência esta que a disposição fundamental da angústia possibilita. A estranheza derivada da angústia, a sensação de não pertencimento, não familiaridade, de que as coisas não possuem mais aquele sentido evidente de antes, faz com que afundemos em indiferença. Não é uma coisa ou outra do mundo que nos escapa: é o próprio ente na totalidade enquanto tal, e, nesse sentido, o próprio mundo. A angústia nos suspende ${ }^{64}$, e nada há para nos apoiar. Experimentamos o abismo, o fundo sem fundo que é, em essência, o próprio mundo. Tal experiência causa-nos vertigens, mas não temos palavras para descrevê-la. Se formos questionados quanto ao que nos angustiávamos tanto, só haveria uma resposta possível: nada. Quais as consequências dessa experiência do nada? Seria isso a afirmação do niilismo, no sentido de uma resignação ante o abissal nada do mundo? Ou, antes, a possibilidade de sua superação?

\footnotetext{
${ }^{64}$ HEIDEGGER, O que é metafisica?. In:
} Marcas do caminho, p. 122. 


\section{A analítica da estranheza}

É com minhas idéias que tremo, com a minha consciência de mim,/Com a substância essencial do meu ser abstracto/Que sufoco de incompreensivel,/Que me esmago de ultra-transcendente, $/ E$ deste medo, desta angústia, deste perigo do ultra-ser,/Não se pode fugir, não se pode fugir, não se pode fugir! $!^{1}$

Álvaro de Campos

Na pergunta pela essência do humano, que traz já consigo a pergunta pelo sentido de ser, vimos que o homem é um ente peculiar, privilegiado. E isso porque, sendo, o homem já sempre compreendeu ser. O modo de ser humano é distinto de o de todos os demais entes. Todos os demais entes, em verdade, manifestam-se como um ou outro modo de ser apenas para o humano, na medida em que ele compreende ser. Não se trata, portanto, de que um ente qualquer, uma mesa, por exemplo, possua rigidamente um modo de ser específico e próprio. Ao contrário, ela, a mesa, pode vir à luz como um manual, como subsistente etc., dependendo de como o homem esteja afinado para com ela. O modo de ser dos entes é relativo ao modo como o homem os compreende em sua manifestabilidade própria. No entanto, só o homem é o ente que possui o modo de ser da existência. Por isso ele é privilegiado, e por isso ele alberga em si a questão do ser. Desse modo, o homem não é só estranho, ele é o mais estranho, o estranhíssimo. Sendo o sítio do ser, o homem é designado, de modo radical, como ser-aí. Que na língua alemã "ser-aí" (Da-Sein) e "existência" (Dasein) sejam designados pela mesma palavra não é casual.

Foi dito anteriormente que o ser-aí não é um “eu”. Mas eu, sempre e a cada momento, já sou um ser-aí. Pode parecer, portanto, que o ser humano, enquanto ente dotado de ser-aí, possui uma natureza dupla, a saber: um "eu" empírico e uma estrutura por detrás que o precede. Chegou mesmo a ser dito que o "eu" era epigonal, posterior, derivado. Mas compreender isso dessa forma involve cair em um erro grave: a relação com o tempo. Desse modo, não se trata

\footnotetext{
${ }^{1}$ PESSOA, Poesia completa de Álvaro de Campos, p. 255.
} 
de uma natureza dupla no sentido de um anterior e um posterior, um antecedente um consequente, um antes e um depois. O próprio termo "natureza" já é problemático, dado que ele costuma ser entendido como essentia, concepção metafísica que não cabe aqui nesta discussão. Eu e ser-aí é um duplo que na verdade é uno, ao mesmo tempo. Um é o avesso do outro. Dá-se como uma dobra, em que o ser-aí seria o vértice, o hífen da estrutura ôntico-ontológica. É pensando assim que faz sentido falar em uma busca de si-mesmo, em tornar-se quem é.

Vital aqui é este "quem". Ante todos os demais entes, que podem ser questionados quanto ao seu "quê", à sua "quididade", os entes dotados de ser-aí são de outra ordem, outro modo de ser radicalmente diferente. O perene movimento do ser-aí em direção ao seu próprio é o que constitui um “quem”. Na maior parte das vezes, no entanto, o "quem" do ser-aí confunde-se com o impessoal. "Quem" o ser-aí é é o seu si-mesmo, o seu próprio, mas lembremos que é estrutural do ser-aí fugir de si-mesmo. O dizer "eu" fático apenas afirma o "quem" do impessoal, pois eu falo como se fala, penso como se pensa, sinto como se sente, entendo como se entende. Pode algo trazer mais estabilidade que isso? O sentimento de pertença a um todo maior que eu, a segurança de que sou "normal", o aconchego do lar.

O tema da estranheza não deve ser tomado levianamente justamente porque trata do rasgo que, irrompendo, impõe-se e expõe a fragilidade desse conforto. Mas o que Heidegger atentamente observou é que isso não diz respeito a uma experiência mística que nega a vida banal, "decaída", "pecaminosa", o "amor concupisciente ao mundo" em prol de um "amor de caridade" que nega o "eu" e visa uma nova ordem de pura e espontânea doação de si. Não. "O ser-si-mesmo de maneira própria determina-se como uma modificação existenciária (Existenziell) do impessoal"2. Essas pré-compreensões mencionadas, em certa medida inevitáveis, isto é, o fato de sempre inicialmente tendermos a leituras e interpretações condicionadas por nossas concepções prévias, é significativo. Nenhum de nós inventou ou criou essas categorias, não passamos por um processo explícito de convencimento de que é assim que as coisas são. Temos essas opiniões arraigadas em nós porque já sempre estivemos imersos num mundo em que elas preponderam. Por serem opiniões adquiridas irrefletidamente, ao

\footnotetext{
${ }^{2}$ HEIDEGGER, Ser e tempo, §54, p. 345.
} 
lermos sobre a história da filosofia, entendida enquanto um conjunto de opiniões, doutrinas e sistemas de pensadores, parece que eles apenas explicitam aquilo que intuitivamente já sempre sabíamos, dão razões e sentido àquilo que já dávamos como certo mas nunca nos tínhamos dado ao trabalho de aprofundar. É por conta disso que nos é "permitido" "discordar" dos grandes pensadores, quando eles não parecem se adequar ao que tomamos como certo. Na era da técnica como último estágio, e portanto a culminação da metafísica, a tendência é sempre a proliferação desse tipo de comportamento ante a filosofia. Tendemos sempre para o unidimensional.

Que é, pois, ser si-mesmo de maneira própria? Disse Heidegger acima: uma modificação existenciária do impessoal. Impessoal aqui não é ninguém determinado. Não é esta ou aquela pessoa, tampouco nenhum grupo, ou a soma da população mundial. É um “quem” neutro, todos e ninguém. Desse modo, o impessoal é o modo de ser da cotidianidade. Nele, reina a obviedade, nada é surpreendente, nada é espantoso. Na cotidianidade, está-se sempre informado sobre tudo, sobretudo hodiernamente, em que cada um de nós carrega no bolso um aparelho que possui uma capacidade de busca e pesquisa sem precedentes na história, tudo ao toque de um dedo. Sabe-se tudo, ouve-se falar de tudo. "Tudo que é originário se vê, da noite para o dia, nivelado como algo de há muito conhecido. O que se conquista com muita luta torna-se banal. Todo segredo perde

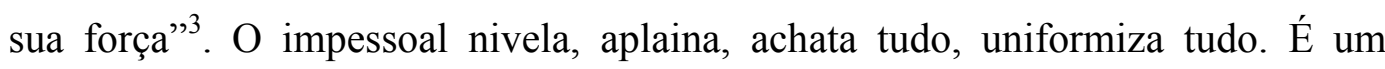
radical "desencantamento do mundo", na famosa expressão de Max Weber. Sem espanto, sem sagrado, sem sensibilidade para qualquer coisa que transcenda o próprio cotidiano. Contudo, quem lê isso e abre um sorriso de desdém ao contemplar o senso comum e suas tolices, com ar de superioridade, não percebe que já está inserido nessa lógica, pois ele próprio desdenha do senso comum e do banal como cotidianamente se desdenha, ele repudia o que é "do povo" como se repudia, ele foge das multidões como se foge. Lembremos, trata-se de um existencial do ser-aí, o impessoal é estrutural, constitutivo de nossa existência.

Ora, mas se já sempre estamos inseridos no impessoal, jogados na cotidianidade, se isso nos constitui, como se pode advogar um ser si-mesmo em sentido próprio? Seria algum tipo de elitismo, onde uns poucos conseguem

\footnotetext{
${ }^{3}$ HEIDEGGER, Ser e tempo, §27, p. 184.
} 
altivamente erguer-se ante a massa ignorante que mantém-se nas trevas da rotina? Veremos. Trata-se de um tema central para o projeto de uma analítica existencial, por isso não convém afirmarmos nada previamente sem antes investigar. Para tanto, um primeiro passo é tratarmos da questão da responsabilidade. O impessoal toma para si a responsabilidade de nossa existência fática, logo, na cotidianidade, ninguém é responsável, pois o impessoal retira a responsabilidade do ser-aí, nos escusa do encargo de tomarmos nossas próprias decisões. Que isso seja assim ontologicamente pode ser onticamente comprovado. Pensemos em um grupo de crianças, travessas como manda a idade, aprontando coisas como tocar as campainhas das casas do bairro e saírem correndo depois. Esta atividade só é feita em grupo, pois a culpa e a responsabilidade se dissolvem no grupo. Jamais uma criança sozinha faria uma coisa dessas. Além do risco de ela ser pega, tendo assim que arcar com a total responsabilidade pelo ato, não teria graça nenhuma fazer isso sem um público para ver e aprovar. A publicidade nos conforta com um sentimento de pertencimento, e é doce a sensação de não se sentir responsável por nada.

O impessoal encobre até mesmo o ter-se dispensado do encargo de escolher explicitamente tais possibilidades. Fica indeterminado quem "propriamente" escolhe. Essa escolha feita por ninguém, através da qual o ser-aí se enreda na impropriedade, só pode refazer-se quando o próprio ser-aí passa da perdição do impessoal para si mesmo. Essa passagem, no entanto, deve possuir o modo de ser por cuja negligência o seraí se perde na impropriedade. A passagem do impessoal, ou seja, a modificação existenciária do impessoalmente si mesmo para o ser-si-mesmo de maneira própria deve cumprir-se como recuperação de uma escolha. Recuperar a escolha significa escolher essa escolha, decidir-se por um poder-ser a partir do seu próprio si-mesmo. Apenas escolhendo a escolha é que o seraí possibilita para si mesmo o seu poder-ser próprio ${ }^{4}$.

Por não ser capaz de nem mesmo escolher sua escolha, como aquilo próprio seu, já que é uma escolha sua, o impessoal deixa velado o próprio do seraí. O impessoal encobre, impede que o ser-aí apreenda suas possibilidades próprias. Por conta disso, “o ser-aí, enquanto convivência cotidiana, está sob a tutela dos outros. Não é ele mesmo que é, os outros lhe tomam o ser" ${ }^{\prime 2}$. Ter o seu ser tomado pelos outros significa não assumir a responsabilidade pelas suas possibilidades de ser. Entrega-se, delega-se ao impessoal o ônus da sua existência.

\footnotetext{
${ }^{4}$ Idem, ibidem, §54, p. 346.

${ }^{5}$ Idem, ibidem, §27, p. 183.
} 
Desse modo, parece ser natural a indagação: e como é possível, então, libertarmonos das garras do impessoal? Como é que saímos de seu domínio? Não saímos, não nos libertamos. Pensar na liberdade como "liberdade de", como ausência de constrangimentos, como não-coerção, é insuficiente, sendo chamada pois de liberdade negativa. Que uma tal liberdade possa existir existenciariamente é-nos aqui indiferente, dado que, justamente por se dar no âmbito ôntico-existenciário, está já sob a égide do impessoal, em nada satisfazendo nossa questão. Há de se pensar em uma liberdade positiva, isto é, dentro da cotidianidade, desde dentro dela, podermos ser livres-para, livres para assumirmos nossas possibilidades. É esse ser livre-para que define o que seria o comprometimento, a responsabilidade com nosso próprio ser, com nossa existência.

Enquanto existencial, a possibilidade não significa um poderser solto no ar, no sentido de uma "indiferença do arbítrio" (libertas indifferentiae). Sendo essencialmente disposto, o ser-aí já caiu em determinadas possibilidades e, sendo o poder-ser que ele é, já deixou passar tais possibilidades, doando constantemente a si mesmo as possibilidades de seu ser, assumindo-as ou mesmo recusando-as. Isso diz, no entanto, que para si mesmo o ser-aí é a possibilidade de ser que está entregue à sua responsabilidade, é a possibilidade que lhe foi inteiramente lançada. O ser-aí é a possibilidade de ser livre para o poder-ser mais próprio ${ }^{6}$.

Nossa existência é um perene assumir e deixar escapar possibilidades, onde tais possibilidades não são as possibilidades lógicas, vazias e abstratas, e sim a própria realidade do ser-aí. Para a lógica, o efetivo, e mais ainda o que é logicamente necessário, possui um primado ante o possível. O possível seria "menos", pois é algo "virtual”; para a existência, no sentido heideggeriano, dá-se o inverso: o possível é que possui a primazia ante o efetivo ${ }^{7}$. Possível aqui não no sentido de uma contingência, do que pode ou não se efetivar, isto é, não visto e julgado a partir do ente, entendido como aquilo de real e efetivo enquanto tal. Ver e julgar a partir do ente marca o caráter do questionar metafísico, caráter esse que é próprio da lógica. Difícil é sermos capazes de compreender e sustentar o possível enquanto possível, de modo a perceber que o ser-aí, propriamente,

\footnotetext{
${ }^{6}$ Idem, ibidem, §31, p. 204.

7 "É somente no seer (Seyn) que se essencia como a mais profunda abertura de seu fosso abissal o possivel, de tal modo que é sob a forma do possível que o ser precisa ser pensado em primeiro lugar no pensar do outro início (a metafísica, contudo, torna o "real e efetivo" enquanto ente o ponto de partida e meta da determinação do ser)". HEIDEGGER, Contribuições à filosofia, §267 p. 459.
} 
distingue-se de todos os demais entes, dado que ele, nesse sentido, não é nada de efetivo, pois seu modo de ser é o da existência, e isso aqui quer dizer: ser poderser, ser suas possibilidades de ser. O efetivo é algo, concreto, real; o possível, enquanto tal, é nada. Por conta disso, quando Heidegger recoloca aquela questão radical da metafísica, a saber: "por que há afinal ente e não antes o nada?"8, ele não está questionando-a de modo metafísico, isto é, ele não está pondo a questão de qual é a razão de haver coisas, qual a causa primordial delas etc. Ele está questionando-se: por que darmos primazia ao ente, e não antes ao nada? Por que que já imediatamente vemos o nada como algo negativo, dado que ele é o nãoente? Somos capazes de sustentar a questão pensante acerca do nada?

A experiência do nada dá-se com a angústia. Não experimentamos o nada como se o apreendêssemos pelos sentidos. Somos como que experimentados por ele, atravessados, tomados pelo nada. Somos nada. Embora sejamos entes, pois já sempre somos projeto jogado na facticidade, somos radicalmente diferentes de qualquer ente em-si. Embora ônticamente sejamos os mais conhecidos para nós próprios, somos ontologicamente os mais estranhos. Próximos às coisas ao nosso redor, estamos já o mais distante possível de nós próprios; distantes das coisas e do mundo, nosso próprio pode se mostrar. É a esse distanciamento que chamamos angústia. A angústia nunca se dá como experiência direta, embora ela esteja sempre à espreita. "A angústia está aí. Ela apenas dorme. Seu hálito palpita sem cessar através do ser-aí" "9. A banalidade do dia a dia se apresenta como vazia, insuficiente, e nos parece indiferente se vivemos ou não. Há um cansaço da vida, uma exaustão que, de tão profunda, passa-se por estrutural, como se fosse nossa essência mais profunda. É esse silêncio ensurdecedor, mesmo em meio à barulheira e falatório cotidianos, que arranca a angústia de seu velamento. No fundo, somos, em certo sentido, a própria diferença ontológica. Somos entes, mas somos ser-aí. Somos velamento que se desvela, um fechado que se abre e torna a fechar, finitude e liberdade, vida e morte. O dar-se da angústia é um nascer e morrer em um instante, abertura para o ser que é fechamento para o mundo, e por isso é a angústia uma disposição fundamental.

\footnotetext{
${ }^{8}$ Cf. HEIDEGGER, Introdução a "O que é metafisica?". In: Marcas do caminho, p. 393ss.

${ }^{9}$ HEIDEGGER, O que é metafisica?. In: Marcas do caminho, p. 128.
} 
Essa liberdade para nossas possibilidades próprias advinda do angustiarse marca nosso abismo em relação aos demais entes. Se o determinante fosse nosso caráter ôntico, se o fundamental fosse ver-nos como subsistentes (Vorhanden), seríamos estáticos, e assim se constituiria nossa rígida, já que universal, essência humana. No entanto, somos ek-státicos, postos, dispostos (stásis) abertamente, para fora (ex). Sendo, estamos sempre fora de nós próprios. Por isso estamos sempre precedendo a nós mesmos, nossas possibilidades são o real. Sabermo-nos ek-státicos é assumir a responsabilidade de nosso projeto. Esse é o sentido mais originário da compreensão (Verstehen) ontológica: antes de uma pré-compreensão das coisas de nosso mundo circundante, já sempre compreendemo-nos a nós próprios e às nossas possibilidades desta ou daquela maneira, deste ou daquele modo. Compreender é o projetar de nosso projeto, um projeto que é projétil, na medida em que, disparado, está sempre em processo de antecipação. Que êxtase, em português, signifique arrebatamento, arroubo, maravilhamento e espanto, um "não nos contermos em nós mesmos", não deve ser encarado displicentemente, tendo em vista o que já foi dito.

Desse modo, não à toa que Heidegger, ao ler a tragédia Antígona, de

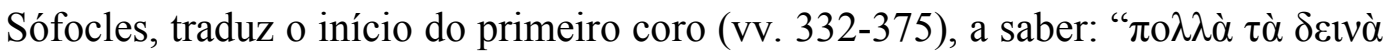

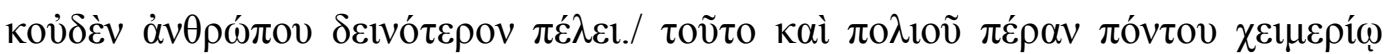
vó $\varrho^{" 10}$, do seguinte modo: "Vielfältig das Unheimliche, nichts doch/über den Menschen hinaus Unheimlicheres ragend sich regt"11, ou seja, "Múltiplo (é) o estranho, nada, porém,/para além do homem, de mais estranho há" ${ }^{\prime 12}$. Muitas são as coisas que podemos achar estranhas em nossa lida diária, muitas são as coisas que podem nos causar espanto, mas nada chega aos pés do homem. Ele não só é estranho, é o estranhíssimo, o mais estranho dentre tudo que pode haver de estranho. O humano do homem é algo de outra ordem. O humanismo, no entanto, ao já sempre pressupor uma pré-compreensão metafísica do humano, e "metafísica" aqui quer dizer partir do ente como critério e medida do ser, é e será sempre débil, insuficiente, indigno. Contudo, esse privilégio - que literalmente significa "lei própria" - não deveria ser entendido como supremacia, tal como

\footnotetext{
${ }^{10}$ Cf. HEIDEGGER, Introdução à metafísica, p. 161.

${ }^{11}$ HEIDEGGER, GA 40, p. 155.

${ }^{12}$ HEIDEGGER, Introdução à metafisica, p. 161.
} 
afobadamente o foi pela modernidade, cujo projeto é o de fazer com que os homens sejam "senhores e possuidores da natureza"13.

Justamente por ser o mais estranho (unheimlich) dentre tudo que há e é, o homem é o mais desenraizado, o mais desolado, o mais carente de pátria. Vendo nisso um mal, tomou providências para assenhorear-se da Terra, seguindo o destino epocal que culminou na cibernética, em nossa era de vigência da técnica. Também isso passa pelo império do impessoal, na medida em que, sob a égide da publicidade, a responsabilidade é dissolvida, como visto. Diz Heidegger que o homem é o pastor do $\operatorname{ser}^{14}$. A metáfora pastoril é oportuna, porque não nos passa a ideia de posse, não dá a entender que o homem é dono do ser, senhor dos entes, e que pode, assim, manipulá-los a seu bel-prazer. Pastor diz aquele que vigia, toma conta, mantém, protege, zela, cuida. A noção de cuidado é a que aqui nos é essencial.

A analítica existencial mostra que o ser do ser-aí é cuidado (Sorge). Ora, se em dado momento Heidegger havia dito que a "essência" do ser-aí é a existência, podemos entender que existência é cuidado. No contexto de $\operatorname{Ser} e$ tempo, cuidado diz principalmente um "cuidado de si" enquanto o cuidado de ser, isto é, o cuidado que o ser-aí deve ter com suas possibilidades de ser, o que significa, no limite, assumir a responsabilidade pela sua própria existência, tomar para si o seu projeto de ser. Vimos que, apesar de isso ser a própria essência do ser-aí, ela encontra-se velada de início e na maior parte das vezes, dado que já sempre nos encontramos imersos na publicidade do impessoal. Desse modo, não só a existência do ser-aí é cuidado, como a facticidade, o fato do ser-aí sempre já se encontrar decaído, também deve ser cuidado; de outro modo: o cuidado, enquanto o todo do ser-aí, deve ser aquela estrutura ontológica que unifica existencialidade e facticidade, que traz para a luz a copertinência estrutural e originária dessas duas dimensões do ser-aí. É nesse sentido que o cuidado é a essência do ser-aí. Ser-aí, pois, é o ser-no-mundo que, já desde sempre decadente, isto é, lançado na cotidianidade mediana, está junto ao "mundo", quer dizer, lida com as coisas de seu mundo circundante, como também já sempre é-com-osoutros, e a par de tudo isso está em jogo sua existência, ou seja, deve projetar-se

\footnotetext{
${ }^{13}$ DESCARTES, Discurso do método, VI, p. 63.

${ }^{14}$ Cf. HEIDEGGER, Carta sobre o humanismo.
} 
ao seu próprio, já sempre compreendendo suas possibilidades de algum modo, antecipando-se e indo ao encontro delas, na medida em que se decide por uma em detrimento de outra, disposto de alguma forma. Dito de modo sucinto, ser-aí é cuidado, onde cuidado abarca todas essas estruturas mencionadas acima.

Que significa "existência" em Ser e tempo? A palavra designa um modo de ser e, com efeito, do ser daquele ente que está aberto para a abertura do ser, na qual ele se situa, enquanto a sustenta. Esse sustentar é experimentado sob o nome "cuidado". A essência ekstática do ser-aí é pensada a partir do cuidado, assim como, inversamente, o cuidado só pode ser experimentado de modo satisfatório em sua essência ekstática. (...) Aquilo que deve ser pensado sob o nome "existência", quando a palavra é usada no interior do pensamento que pensa na direção da verdade do ser e a partir dela, poderia ser designado, do modo mais belo possível, pela palavra "insistência"15.

A insistência é o insistir na facticidade, é o sempre voltar-se e retornar para a lida com as coisas na cotidianidade, é o insistir na rotina e no hábito, como é característico do ser-aí, pertence à sua constituição íntima. A decadência se constitui como cadência. O ser-aí insiste no seu "aí". Isso, porém, só é possível porque o ser-aí já sempre é ek-stático, ou seja, ele está sempre na possibilidade de poder romper com o impessoal, cessar a fuga de si e lidar com o seu próprio. Pelo fato do ser-aí ser projeto lançado ek-stático, há este vaivém, este jogo de desvelamento e velamento, abertura e fechamento, luz e sombra. Como o cuidado é o ser do ser-aí, ele é a sustentação deste jogo, deste vaivém. Cuidado é insistir na abertura do ser e o poder abrir-se para seu próprio ser em meio a essa abertura do ser.

Sempre já disposto de algum modo, encontrando-se no mundo de algum modo, e, por conseguinte, afinado para com as coisas de algum modo, o ser-aí compreende-se também a partir de algum modo. Como a compreensão de si, em certo sentido, já sempre se deu, a disposição parece ser determinante na interpretação dessa compreensão existencial, no modo dessa interpretação fazer com que a compreensão de si venha à fala. A interpretação é a compreensibilidade das possibilidades do ser-aí. Daí que "a fala é a articulação 'significativa' da compreensibilidade do ser-no-mundo"" . Heidegger pôs o "significativo" entre

\footnotetext{
${ }^{15}$ HEIDEGGER, Introdução a "O que é metafisica?". In: Marcas do caminho, p. 386.

${ }^{16}$ HEIDEGGER, Ser e tempo, $\$ 34$ p. 224. Seguimos aqui a tradução revisada de Márcia Sá Cavalcante Schuback, que passou a traduzir Rede por fala, ao invés de discurso.
} 
aspas para marcar a diferença da concepção corrente da linguagem, onde a fala é a pronunciação de palavras com certo significado cujo fim é a comunicação de ideias. O vir à fala da compreensão de ser não quer dizer representar ideias por meio de palavras, conceitos adequados a tais ideias, como se tivéssemos em mente as nossas possibilidades e pudéssemos expressá-las. A fala não é uma peculiaridade humana entendida como expressão de sinais fonéticos, não é da ordem do ôntico, ao menos não originariamente. "Do ponto de vista existencial, a fala é igualmente originária à disposição e ao compreender”. Com efeito, a fala também compõe a estrutura do "aí" do ser-aí. Ela articula disposição e compreensão, dando o sentido da interpretação existencial. A fala propicia o sentido do mundo do ser-no-mundo.

Mundo é o nosso horizonte de sentido. Enquanto tal, o mundo é linguagem. Linguagem, novamente, não como uma aptidão ou faculdade humana, não como a expressão de uma língua historicamente constituída por um povo, não como comunicação por via de enunciados e proposições. Linguagem aqui diz: $\lambda$ óyos (lógos). Com isso não se deve entender que o mundo seria fruto de uma razão organizadora, dada a contingência histórica de $\lambda$ ó ${ }_{0} \varsigma$ ter sido compreendido como ratio, razão. Tampouco deve-se entender $\lambda$ ó $o \varsigma$ como verbo, palavra. Quanto a isso, Heidegger assevera:

No entanto, $\lambda$ ó ${ }^{\circ} \varsigma$ originariamente não significa discurso, nem

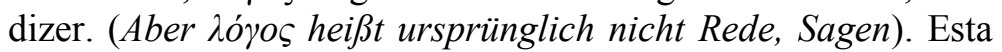
palavra não tem no seu significado qualquer referência imediata à linguagem. Lego, legein, legere em latim é a mesma palavra que a alemã "lesen"; "Ähren lesen" (colher espigas), "Holz lesen" (juntar ou apanhar lenha), "die Weinlese" (a vindima), "die Auslese" (a seleção); "ein Buch lesen" (ler um livro) é apenas um derivado de "lesen" no seu sentido original. "Lesen" significa: pôr uma coisa ao lado de outra, juntá-las num conjunto, sem síntese: coligir, compilar, colecionar (sammeln); ao fazê-lo, vai-se, ao mesmo tempo, distinguindo uma coisa da outra ${ }^{17}$.

$\Lambda$ óyoৎ seria, pois, uma reunião reunificadora, um recolher numa unidade de sentido, não de modo desleixado, grosseiro, mas com harmonia. Já Aristóteles

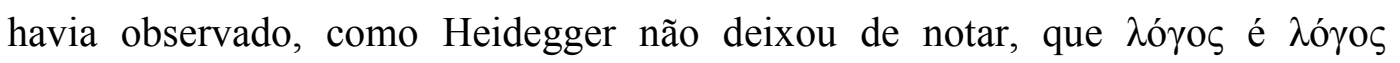

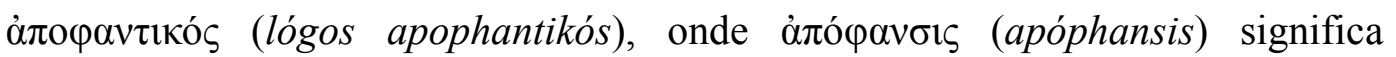

\footnotetext{
${ }^{17}$ HEIDEGGER, Introdução à Metafisica, p. 137.
} 
"deixar e fazer ver o ente a partir dele mesmo e por si mesmo"18. Com efeito, sendo a linguagem originariamente "apofântica" (cuja raíz etimológica é a mesma de fenômeno), ela é sempre "mostradora", ela dispõe os entes de algum modo à nossa compreensão. Por conta disso é que ela oferece o sentido de ser das coisas de nossa lida e, por conseguinte, é nesse sentido que o mundo é linguagem. Ser e estar no mundo é já sempre ter compreendido as coisas de algum modo, pois elas já foram assim dispostas e oferecidas de tal modo pela linguagem. A linguagem é essa clareira que põe em aberto as coisas, que mostra, que as ilumina de algum modo à nossa compreensão. A fala é justamente o silêncio dessa compreensão, a escuta - que no fundo é um auscultar - do sentido do mundo. Quando se enuncia as coisas do mundo, a nossa compreensão delas, é porque a fala já sempre se deu, o sentido já sempre foi compreendido, e por isso podemos expressar isso pela "fala" no sentido do dizer corriqueiro. Por conta disso é que, propriamente, "a Linguagem fala"19, e não o homem. Quando o homem "fala", é porque a linguagem já sempre falou por ele, para ele e através dele.

Mas só muito raramente escutamos o silêncio que é a fala da linguagem. Considerando, mais uma vez, que, de início e na maior parte das vezes, o ser-aí encontra-se lançado em meio à cotidianidade mediana, à publicidade do impessoal, o sentido oferecido pela linguagem, nosso mundo, não se mostra como um sentido próprio. Há um sentido público, impessoal. Heidegger dá o nome de falação (das Gerede) a esse modo de ser do compreender e da interpretação do ser-aí cotidiano ${ }^{20}$, enquanto a contraposição ôntica da fala, entendida ontológicoexistencialmente. A primeira impressão que temos ao depararmo-nos com este termo é o compreendermos de modo pejorativo, pois o associamos a pessoas tagarelas falando sem parar sobre qualquer coisa, o que sempre acarreta a ideia de superficialidade, de frivolidade. Não é o caso. A fala decai em falação enquanto comunicabilidade do ser-aí. Trata-se, portanto, de algo positivo e constitutivo do ser-aí, enquanto compõe estruturalmente sua facticidade. Acontece que essa comunicação dá-se no âmbito da compreensibilidade mediana, isto é, da compreensão impessoal, decaída, e, portanto, epigonal. Em certo sentido, trata-se do que foi aqui anteriormente chamado de senso comum, isto é, uma compreensão

\footnotetext{
${ }^{18}$ HEIDEGGER, Ser e tempo, §33, p. 216.

${ }^{19}$ HEIDEGGER, A caminho da linguagem, p. 9.

${ }^{20}$ HEIDEGGER, Ser e tempo, §35, p. 231.
} 
mediana e comum a todos, opiniões previamente estabelecidas aceitas por todos, um âmbito confortável, já que mediano, para as idiossincrasias de todos.

Este tipo de interpretação própria da falação já se consolidou no ser-aí. É dessa maneira que aprendemos e conhecemos muitas coisas. É dessa maneira ainda que não poucas coisas jamais conseguem ultrapassar uma tal compreensão mediana. O ser-aí nunca consegue subtrair-se a essa interpretação cotidiana em que ele cresce. Todo compreender, interpretar e comunicar autênticos, toda redescoberta e nova apropriação cumprem-se nela, a partir dela e contra ela. Não é possível um ser-aí, que não sendo tocado nem desviado pela interpretação mediana, pudesse colocar-se diante da paisagem livre de um "mundo" em si, para apenas contemplar o que lhe vem ao encontro ${ }^{21}$.

Isso significa que, em vez da concepção moderna - seu esteriótipo, ao menos - de que somos sujeito, enquanto coisa pensante, que se relaciona "de fora" com o mundo, enquanto uma coisa distinta, "separada", Heidegger está mostrando que já sempre somos historicamente determinados e condicionados, isto é, sempre que nos damos conta já nos encontramos num mundo previamente dado, com uma história, valores, descobertas, opiniões, saberes, costumes etc. já definidos, e que sempre, querendo ou não, somos marcados por tudo isso, é a partir disso que existimos, e, por conseguinte, é somente a partir disso que podemos assumir nossa existência autêntica. Não existe nada de autêntico em nós que não parta de nossa determinação histórica "inautêntica" previamente estabelecida, somos sempre e necessariamente frutos de nossa configuração histórica, que é prévia e fundante.

O "problema", entretanto, é quando esses "preconceitos" necessários e fundamentais para a existência são assumidos como a verdade última. Justamente pela sua importância, transgredi-los é tarefa árdua e solitária. Pelo fato de eles se darem num âmbito de compreensibilidade mediana, impessoal, logo, passível de ser compreendido por todos, a tendência é a sua aceitação inconteste. A falação é autoritária, porque é o senso comum e, assim, é de comum acordo - mesmo que tacitamente - para todos que as coisas são tais como são. Isso é assim porque sim e ponto final. Não se toca nada de essencial sobre nada, apenas passa-se adiante o que é tido como essencial. É o reino da obviedade, que pressupõe uma ausência de questionamento. Não questionar as coisas, ter as mesmas opiniões sobre tudo em comum com todos, não precisar pensar, pois o que é óbvio e evidente não dá a

${ }^{21}$ Idem, ibidem, §35, p. 233. 
pensar, é cômodo, proporciona aquele conforto do familiar, e por isso apelamos à essa autoridade sempre que conveniente.

Além do mais, nós mesmos nos movimentamos no nível de compreensão do senso comum, na medida em que nos cremos em segurança no interior das diversas "verdades" oriundas da experiência de vida, da ação, da pesquisa, da criação e da fé. Nós mesmos participamos da revolta do "óbvio" contra tudo o que exige que ele seja posto em questão $0^{22}$.

Outra característica da falação é a determinação daquilo que "vale a pena" ser lido e visto. Em nossa lida cotidiana para com as coisas em nosso mundo circundante, somos sempre guiados por uma circunvisão (Umsicht) que previamente garante a apropriação de uma compreensão de nossa lida instrumental, vinda à tona como tal apenas quando ocorre o fenômeno da surpresa, previamente mencionado. Tem-se, pois, a visão como uma metáfora para a compreensão mediana. Não se trata de algo casual, tendo em vista que, ontológico-existencialmente, a abertura do "aí" do ser-aí foi determinada como clareira (Lichtung), cuja luminosidade evoca a visão, concebida como modo fundamental de abertura própria do ser-aí. Há, pois, em contrapartida, o fenômeno ôntico-existenciário do "ver", que Heidegger chama de curiosidade. Trata-se de mais um caráter positivo que estrutura o impessoal, juntamente com a falação.

As coisas alardeadas pela falação tornam-se alvo de curiosidade. Assim como a falação, que tudo comunica de modo inessencial, e passa adiante informações sem que nelas se tenha pensado mais detidamente, a curiosidade é a sanha de se querer ver tudo, mas que, propriamente, não vê nada, nada em sentido essencial.

A curiosidade liberada, porém, ocupa-se em ver, não para compreender o que vê, ou seja, para chegar a ele num ser, mas apenas para ver. Ela busca apenas o novo a fim de, por ele renovada, correr para uma outra novidade. Esse acurar em ver não trata de apreender e nem de ser e estar na verdade através do saber, mas sim das possibilidades de abandonar-se ao mundo. Por isso, a curiosidade caracteriza-se, especificamente, por uma impermanência junto ao que está mais próximo. (...) Em sua impermanência, a curiosidade se ocupa da possibilidade contínua de dispersão ${ }^{23}$.

Pensar as coisas de modo essencial exige uma permanência junto a elas, uma demora, um ritmo dado pela própria coisa. O afã do novo impede tal

${ }^{22}$ HEIDEGGER, Da essência da verdade. In:

${ }^{23}$ HEIDEGGER, Ser e tempo, §36, pp. 236-237. . Marcas do caminho, p. 190. 
permanência, o que propicia uma dispersão do ser-aí no "mundo", de perder-se a si próprio naquilo de mais mundano, logo, no que há de mais banal. Heidegger notou esse fenômeno em 1927, ano em que Ser e tempo foi publicado. Se a contemporaneidade fez algo neste meio tempo, foi comprovar sua intuição. Que melhor exemplo há para se falar de curiosidade e falação do que as redes sociais tornadas possíveis pela internet? Dotadas de uma inigualável capacidade de dispersão - que muitas vezes é subestimada, como todo vício que nos recusamos a admitir que possuímos e que exerce poder sobre nós - não só nunca pensamos tão pouco em nós próprios, paradoxalmente nesta época em que tudo o que parecemos fazer é projetar para o mundo conectado uma ideia narcísica de um "eu" feliz e realizado, isto é, quanto mais ficamos exaustivamente falando sobre nós mesmos, mais nos distanciamos de nosso próprio, como também compartilhamos notícias sem nos dar o trabalho de comprovarmos se a informação é verídica ou não, compartilhamos culpados de crimes que nem sabemos se foram cometidos de fato, ou se aquela pessoa é de fato culpada, dado que ainda não foi julgada, compartilhamos dietas e dicas de saúde pelo simples fato de se falar que elas têm respaldo científico, embora nunca busquemos a fundo quais cientistas, com que tipo de pesquisa e de amostragem, chegaram àquela conclusão, compartilhamos até mesmo citações de grandes pensadores, querendo passar uma ideia de que somos profundos e cultos, quando na verdade tudo que conseguimos é banalizar e violentar questões fundamentais. Recomendamos a todos os que nos seguem quais livros eles devem ler, quais filmes e séries eles precisam assistir, tudo aquilo que uma pessoa deve tomar para si como essencial caso queira continuar vivendo em sociedade sem constrangimentos. E deve-se fazer isso depressa, pois no próximo mês já será lançado o livro tal e estreará o filme tal, que também deverão ser vistos. Não só se deve ler e assistir tudo o que recomendamos, como se deve também gostar, pois são as coisas certas a serem lidas e assistidas. As redes sociais são um hipostasiamento dos fenômenos da falação e da curiosidade. Esses dois fenômenos, que possuem uma reciprocidade intrínseca, viabilizam o terceiro fenômeno estruturador do impessoal: a ambiguidade.

Se, na convivência cotidiana, tanto o que é acessível a todo mundo quanto aquilo de que todo mundo pode dizer qualquer coisa vêm igualmente ao encontro, então já não mais se poderá distinguir, na compreensão autêntica, o que se abre do que não 
se abre. Essa ambiguidade não se estende apenas ao mundo, mas também à convivência como tal e até mesmo ao ser do seraí para consigo mesmo. Tudo parece ter sido compreendido, captado e discutido autenticamente quando, no fundo, não foi. Ou então parece que não o foi quando, no fundo, já foi ${ }^{24}$.

A ambiguidade é a indiscernibilidade entre o próprio e o impróprio, o autêntico e o inautêntico. É a fonte da pretensa superioridade do senso comum ante a filosofia, o pensamento e tudo que diz respeito à criação. Pois toda obra fruto de uma autêntica lida do ser-aí com seu próprio será tida pelo impessoal como algo que um outro qualquer poderia ter feito, ou algo que já se viu algo parecido, não sendo pois “original”. É o que permite também que pessoas entranhadas radicalmente na facticidade pensem que estão sendo autênticas, quando na realidade apenas ecoam o impessoal. A ambiguidade é a expressão do caráter de dobra do ser-aí, da imbricação entre existência e facticidade. Se já sempre estamos em meio ao senso comum, ao teor público do impessoal que dita nossa compreensão e interpretação de nós próprios e do mundo, como distinguimos, em meio a ambiguidade do próprio e do impróprio, o que seria, de fato, nosso próprio? Somente quando o impessoal, que se apresenta como sendo tudo, é visto como nada. E quando percebemos o impessoal, o mundo público, como nada? Quando a angústia nos toma, arrebata, e nos dispõe como estranhos ante o mundo.

O silêncio que então surge, que não é um mero calar da falação, mas antes a própria fala, em sentido ontológico-existencial, que é fala justamente por ser silêncio, é a condição para que, pela primeira vez, ouçamos de fato. Assim como a visão mencionada acima nada tem a ver com nossos olhos, essa escuta do silêncio também não tem nada a ver com nosso aparelho auditivo. Ouvir é um auscultar, no sentido de uma escuta concentrada. Mas concentrada em quê? Não nos sons das coisas do mundo, já que não se trata de nada fisiológico. Ouvimos aquilo que vem recolhido numa reunião, o sentido que, como visto, é o próprio $\lambda$ óyoc. É nesse sentido que a fala, enquanto linguagem, é o próprio silêncio. Esse sentido que vem à fala é o que Heidegger vai denominar apelo (Ruf) da consciência. Ele diz: "O apelo da consciência possui o caráter de interpelação do ser-aí para o seu poder-ser-si-mesmo mais próprio e isso no modo de fazer apelo

\footnotetext{
${ }^{24}$ Idem, ibidem, §37, pp. 237-238.
} 
para o seu ser e estar em dívida mais próprio" ${ }^{25}$. Ora, jogado no impessoal, "ouvindo" apenas a falação, o ser-aí não dá ouvidos ao próprio de si-mesmo. Ele é chamado a tal, em meio ao silêncio proporcionado pela estranheza advinda da angústia, como um apelo da consciência. Consciência, para Heidegger, rompendo com a tradição cartesiana que perpassa até mesmo Husserl, não é a estrutura formal da intencionalidade, nem o sujeito do conhecimento, como já dito ${ }^{26}$. Consciência é um "tomar consciência" de que, estruturalmente, o ser-aí é e está em débito para consigo próprio.

Um passo atrás. Heidegger chamou de cuidado o ser do ser-aí, enquanto constitutivo do seu todo, isto é, aquilo que abarca existência, facticidade e decadência, entendida como projeto lançado. Contudo, o ser todo do ser-aí não é nada de fechado em si próprio, justamente pelo fato do cuidado não ser uma essentia metafísica. É pelo fato de esse todo ser aberto que o cuidado se apresenta como o ser do ser-aí. Ser aberto aqui quer dizer que as possibilidades próprias do ser-aí, embora determinadas historicamente, não são dadas de antemão como certas. Não se trata de um conjunto fechado de possibilidades, onde cada ser-aí tem o seu "pacote" de possibilidades previamente dadas, e a partir delas escolhe uma ou outra, resignado à boa ou má sorte de seu destino. Por ser aberto, ou seja, por ser sempre possibilidade de possibilidades, é que o ser-aí é livre. Liberdade, pois, não como um atributo ou propriedade do ser-aí, mas justamente por ser sempre possível que o ser-aí possa ser livre para suas possibilidades próprias. Mas isso também significa que o ser-aí é sempre também livre para não cumprir com suas possibilidades próprias, por escolher a fuga de si. Por conta disso, o ser-aí está sempre em débito, em dívida para consigo próprio, pois nunca poderá realizar-se propriamente a todo momento, sempre terá que sacrificar possibilidades em prol de outras. $\mathrm{O}$ apelo da consciência é proveninente do cuidado que, despertado pela angústia, faz com que o ser-aí saia da dispersão do impessoal e busque a si próprio, que o ser-aí pare de fugir de si.

Para o ser-aí retirar-se da perdição em que não dá ouvidos retirar-se por ele mesmo - ele deve primeiro poder encontrar a si enquanto o que não deu ouvidos a si mesmo, por ter dado

\footnotetext{
${ }^{25}$ HEIDEGGER, Ser e tempo, §54, p. 347.

${ }^{26} \mathrm{O}$ termo que Heidegger usa e que traduzimos por "consciência" é Gewissen, que possui o sentido de uma "consciência moral". Husserl e Hegel, por exemplo, falam de Bewusstsein, a consciência no sentido do sujeito do conhecimento.
} 
ouvidos ao impessoal. Esse último dar ouvidos deve ser rompido, ou seja, o próprio ser-aí deve dar a si a possibilidade de uma escuta que o interrompa. A possibilidade dessa interrupção reside em ser interpelado (Anruf) sem mediação. Esse apelo rompe o dar ouvidos ao impessoal em que o ser-aí não dá ouvidos quando, de acordo com seu próprio caráter, desperta uma escuta que, em tudo, se contrapõe à escuta perdida. Se este se caracteriza pelo "ruído" da ambiguidade múltipla e variada da falação cotidianamente "nova", o apelo deve apelar sem ruído, sem ambiguidade, sem apoiar-se na curiosidade. $O$ que assim apelando se dá a compreender é a consciência ${ }^{27}$.

Por conseguinte, a consciência não é faculdade da alma, entendimento, vontade, sentimento, ou uma mistura desses elementos ${ }^{28}$. Ela é a manifestação do cuidado, é o chamado à responsabilidade para com suas possibilidades próprias. A fala, em sentido ontológico, refere-se a esse apelo da consciência, que interpela o próprio ser-aí, numa perspectiva em que ele vislumbre, isto é, tenha consciência de seu si-mesmo em sentido próprio, tendo sempre em mente que tal "ter consciência" não se trata de uma racionalização da mente humana, não é um processo inconsciente de um sujeito que passa a ser cognoscível. Em certo sentido, a consciência é o próprio do ser-aí. Ela se dá quando o ser-aí ultrapassa a si enquanto jogado no impessoal. Nesse ultrapassamento do impessoal, as discussões públicas oferecidas pela falação e pela curiosidade são reduzidas à insignificância, o que não significa que o ser-aí se "feche" em si, solipsistamente, contra o "mundo exterior". Como a interpelação do ser-aí se dá quando ele se sente estranho, ocorre que o impessoal se manifesta como nada. $\mathrm{O}$ apelo da consciência é como um chamado.

São Paulo inicia a sua Epístola aos Romanos, um dos textos basilares e, por conseguinte, mais significativos do Ocidente, com a seguinte frase: "Paulo, servo de Cristo Jesus, chamado a ser Apóstolo, escolhido para anunciar o Evangelho de Deus" ${ }^{, 29}$. O texto paulino, escrito originalmente em grego, assim foi

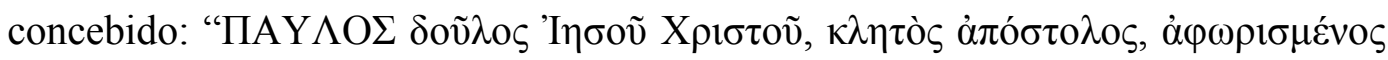

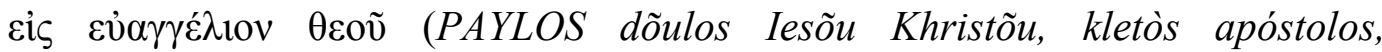

\footnotetext{
${ }^{27}$ HEIDEGGER, Ser e tempo, $\S 55$, p. 349.

${ }^{28}$ Salvo engano, o uso deste termo não volta a aparecer na obra de Heidegger posterior, pois tratase de um termo extremamente complicado, pois acarreta todo tipo de pré-compreensões equivocadas. Como Ser e tempo ainda é uma obra abertamente fenomenológica, talvez a escolha do termo tenha se dado como uma resposta ao pensamento de Husserl, com a diferença de que a consciência, para Heidegger, é pré-subjetiva.

${ }^{29} \mathrm{Rm} 1: 1$.
} 
aphorisménos eis euangélion theõu)". Um único termo desta apresentação nos

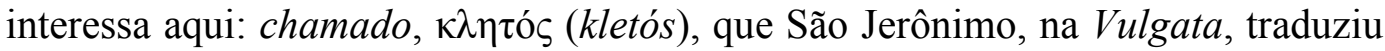

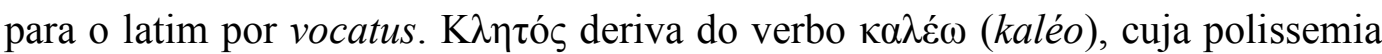

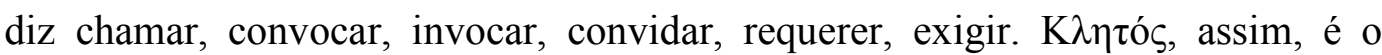
chamado, o convocado, o escolhido, o eleito. A tradução latina por vocatus é precisa, pois significa o mesmo que $\kappa \lambda \eta \tau o ́ \varsigma$ - ou seja, chamado, convocado etc. como também pode significar nomeado, designado. Nossa palavra vocação deriva deste termo.

É comum nossas escolas proporem aos jovens testes vocacionais, a fim de ajudá-los a descobrir qual melhor profissão se adequaria às suas aptidões. Muitas vezes, pessoas largam seus empregos que, embora pudessem ser bem remunerados, não as satisfaziam profissionalmente, dizendo: "não tinha vocação para isso". Contudo, seriam estes testes realmente capazes de determinar as vocações das pessoas? Ou ao menos sugestionar? Analisa-se Fulano. Ele tem "facilidade" com as humanidades em geral, história, literatura, sociologia etc. Estaria apto, então, a ser um professor, bibliotecário ou advogado; Ciclano, por sua vez, não apresenta as dificuldades que normalmente os demais jovens têm com matemática: ele estaria apto, assim, a ser um engenheiro; Beltrano "leva jeito" para biologia, seria um bom médico, e assim por diante. Cada jovem, no momento crítico da escolha de sua carreira, no nosso caso, no término do Ensino Médio, é enquadrado em alguma aptidão genérica de acordo com seu histórico escolar, e deve prestar o vestibular em conformidade com isso. Trata-se de uma exigência de nossa sociedade de mercado, que exige, inclusive, que alguns jovens, que ou por falta de oportunidade ou por, aparentemente, não possuírem "talento algum", devam ser alocados ao setor de serviços, comércio, trabalhos informais, biscates ou coisas do tipo. Não é possível que todos sigam suas vocações, talvez nem seja possível que todos possam ter vocações.

Seria o chamado, a vocação de Paulo, algo do tipo? Ele prestou algum teste vocacional que indicou que ele teria talento, que ele "levaria jeito", para ser apóstolo? Evidentemente não. Mas não podemos afirmar ainda que não haja nenhum resquício desse sentido mais profundo de vocação em nossa compreensão hodierna do texto. Decisiva para essa secularização da $\kappa \lambda \eta \tau$ ćs paulina foi sua tradução por Beruf no alemão, realizada por Lutero. Embora possua uma relação 
etimológica com o verbo rufen, chamar, Beruf, mais do que vocação, deu um sentido de profissão para o $\kappa \lambda \eta \tau$ ó $\zeta$ de Paulo. Essa transformação de sentido não passou despercebida a Max Weber, justamente como um dos pontos de apoio para a tese de sua monumental obra $A$ ética protestante e o espírito do capitalismo, de 1904. Quanto a isso, diz-nos Agamben:

O que ele chama de "espírito do capitalismo" - isto é, a
mentalidade que faz do próprio lucro um bem,
independentemente das suas motivações hedonistas ou
utilitárias - teria origem na ascese profissional calvinista e
puritana, emancipada de seu fundamento religioso. Isso
significa, em outras palavras, que o espírito capitalista é uma
secularização da ética puritana da profissão. Mas esta (...) se
constrói, por sua vez, justamente a partir da passagem paulina
sobre a klêsis (...), transformando a vocação messiânica que
nela está em questão no conceito moderno de Beruf, ao mesmo
tempo vocação e profissão mundana ${ }^{30}$.

A passagem paulina sobre a $\kappa \lambda \tilde{\eta} \sigma 1 \varsigma$ (klêsis) supramencionada por Agamben encontra-se na Primeira Epístola aos Coríntios: "Cada um fique na

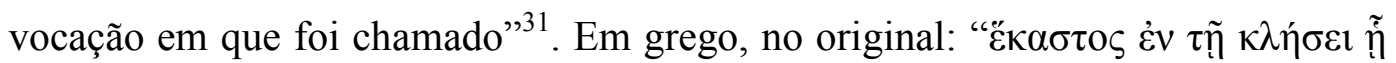

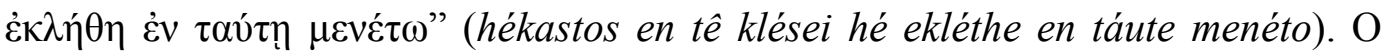
próprio sentido de Igreja, para Paulo, estaria relacionado a isso. Ele diz: "E assim cada um ande como Deus lhe repartiu, cada um como o Senhor o chamou. É o que

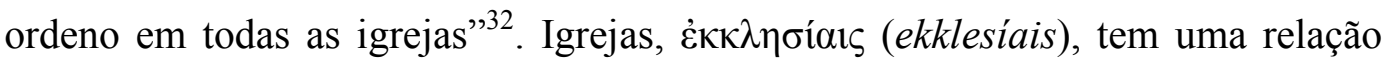

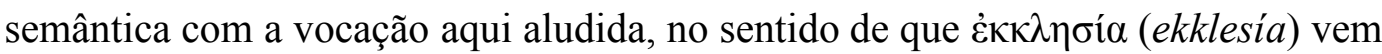
de $\dot{\varepsilon} \kappa(e k)$, para fora, a partir de, e $\kappa \alpha \lambda \varepsilon ́ \omega$, verbo que, como visto, dá origem a

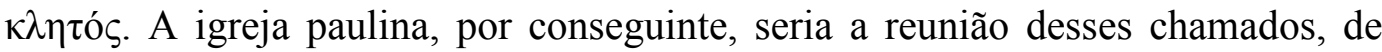
todas as pessoas que despertam para a sua vocação própria.

Entretanto, sem dúvida cabe aqui a objeção: e qual a relevância disso para o tema aqui em questão? Trata-se de um trabalho de teologia? Há aqui alguma pretensão sub-reptícia de proselitismo? São perguntas justas, porém estéreis. Absolutamente, não se trata aqui de qualquer neotomismo, nenhuma nova proposta de união entre a fides e a ratio. Tenhamos em mente, a princípio, o fato, e apenas a título de informação, que Heidegger foi um grande leitor de Paulo e de Lutero $^{33}$. Não seria nenhum absurdo, então, partir da hipótese de que

\footnotetext{
${ }^{30}$ AGAMBEN, O tempo que resta, p. 34

${ }^{31} 1$ Cor 7:20.

321 Cor 7:17

${ }^{33}$ Cf. GA 60, 63 e 80.
} 
Heidegger teria visto neles algo de essencial, e que o seu pensamento tenha sido marcado por eles de alguma forma. E nossa hipótese aqui é de que isso se evidencia em Ser e tempo, deixando em aberto, provisoriamente, se o seu pensamento posterior também teria sido influenciado pelo tema em questão. Naturalmente, rechaça-se aqui qualquer interpretação "mística" do pensamento heideggeriano. Que as epístolas paulinas possam nos ajudar a pensar em conjunto com Heidegger não implica que este não possua a sobriedade suficiente para saber distinguir as regiões temáticas em questão. A propósito, Heidegger, com prudência, indica diversas vezes em Ser e tempo que ele não está justificando racionalmente problemáticas teológicas ${ }^{34}$, mas ao contrário, pelo fato de estar realizando uma analítica existencial enquanto ontologia fundamental, a questão heideggeriana é sempre anterior, mais radical e mais originária - e, pois, já sempre pressuposta, mesmo que implicitamente - que qualquer questão teológica. É pelo fato do ser-aí apresentar-se assim e assim que a religião pode dar-se de tal ou tal modo, ter essa ou aquela questão. Heidegger chega mesmo a dizer que esse fenômeno

foi tomado como ponto de partida para a interpretação da voz enquanto força estranha que se abate sobre o ser-aí. Prosseguindo nessa direção interpretativa, atribui-se essa força instalada a alguém que dela tem posse ou ainda se a toma como uma pessoa que anuncia (Deus). Por outro lado, recusa-se esta interpretação, eliminando a consciência mediante uma explicação "biológica". Ambas as interpretações passam apressadamente por cima do dado fenomenal ${ }^{35}$.

A "voz da consciência" não é , na perspectiva da analítica fundamental, nem a "voz de Deus" nem nada da ordem corpórea, neurológica, fisiológica em geral. Contudo, que o apelo da consciência, tal como a vocação paulina, não seja

\footnotetext{
${ }^{34}$ Quanto a isso, tem-se, por exemplo, a problemática do §10, p. 93 s., onde Heidegger atribui à teologia cristã a importância da noção de transcendência, mas que ainda assim o ser do homem manteve-se inquestionado. No §38, p. 245, Heidegger, ao tratar do fenômeno da decadência, afasta-se de uma concepção de "queda" ou "corrupção da natureza humana", dizendo não que tais temas estão "errados", mas antes que não cabem tais questões na analítica existencial, e que, justamente, os temas da fé é que devem apoiar-se na analítica existencial. Em outras palavras: algo como o pecado original "nem há nem não há", e seria portanto um erro, na ontologia fundamental, advogar qualquer um dos lados. Qualquer defesa ou ataque dessa noção já sempre partiu da ontologia fundamental. Ainda em Ser e tempo, no §62, p. 389, em uma nota, Heidegger faz uma distinção entre o fenômeno existencial da dívida (Schuld, que também pode ser traduzido por débito ou culpa) com a problemática teológica da culpa. Por fim, Heidegger, na Carta sobre o humanismo, p. 340, diz: "Cometeríamos um último engano, no entanto, se quiséssemos explicar a frase sobre a essência ek-stática do homem como se ela fosse a versão secularizada de um pensamento sobre Deus, expresso pela teologia cristã, e transferido ao homem".

${ }^{35}$ HEIDEGGER, Ser e tempo, §57, p. 354.
} 
uma revelação de talentos ônticos para profissões específicas na sociedade está claro. Rigorosamente, o apelo não exprime nada, não nos fala nada, não nos conta nenhum segredo. "O apelo dispensa qualquer verbalização. Ele não vem primeiro à palavra e, não obstante, nada permanece obscuro e indeterminado. A fala da consciência sempre e apenas se dá em silêncio"36. A consciência faz apelo ao simesmo do ser-aí para que ele se ultrapasse, ou seja, para que ele saia da perdição no impessoal. O ser-aí apela-se a si próprio, ele apela e é interpelado. "O apelo provém de mim e, no entanto, por sobre mim"37. Esse "por sobre mim" significa que o apelo se dá independentemente de minha vontade e de meu querer, dado que me transcende, mesmo provindo de mim. Parece um contrassenso, mas Heidegger quer dizer que o apelo não vem "de fora", pois trata-se justamente do próprio do ser-aí, que não pode ser dado por outro, mas que ao mesmo tempo o sobrepassa na medida em que transcende o ser-aí cotidiano.

Como esse apelo traz em si uma tarefa, o chamado à tomar responsabilidade pelo seu projeto, ele é árduo, e daí surge a nossa tendência de fugirmos de nós próprios. O fato do ser-aí fugir desse estar-lançado para o conforto familiar do impessoal foi caracterizado como fuga da estranheza. A estranheza, que é propriamente desvelada com a angústia, é o que perturba a letargia própria do entregar-se ao cotidiano e permite que vençamos a dispersão e o desamparo de sermos impessoalmente nós-mesmos para que possamos nos singularizar. A disposição fundamental da angústia, portanto, é a abertura mais elementar e fundamental do ser-aí, pois é somente "tomando consciência" de sua radical estranheza que o ser-aí pode ultrapassar o "mundo" e ultrapassar-se a si como pertencente a esse "mundo". O ser-aí singularizado pela estranheza se dá conta de que é um abismo que fita outro abismo, um céu contemplando um cânion, um nada diante do nada.

Nada "mundano" pode determinar quem apela em seu modo de ser. Quem apela é o ser-aí em sua estranheza, o ser-no-mundo originariamente lançado enquanto um não sentir-se em casa, o nu e cru "que" (o ser-aí é) no nada do mundo. Quem apela também não é familiar ao impessoalmente-si-mesmo da cotidianidade - é algo como uma voz estranha. O que poderia ser mais estranho para o impessoal, perdido no "mundo" das múltiplas ocupações, do que o si-mesmo singularizado na

\footnotetext{
${ }^{36}$ Idem, ibidem, §56, p. 352.

${ }^{37}$ Idem, ibidem, $\$ 57$, p. 354.
} 
estranheza de si e lançado no nada? O apelo "se" faz e, ao mesmo tempo, nada oferece à escuta do ouvido curioso das ocupações que pudesse ser divulgado e discutido em público. Mas o que o ser-aí deve também relatar a partir da estranheza de seu estar-lançado? $O$ que ainda lhe resta senão o poder-ser de si mesmo, desvelado na angústia? Como se faz o apelo senão enquanto um fazer apelo a esse poder-ser, unicamente em jogo para si? $?^{38}$

Quanto mais nos afundamos no "mundo" das ocupações, quanto mais temos certeza das coisas repetidas e passadas adiante pela falação, quanto menos questionamos sua origem, e deixamos de nos deter na coisa mesma para dela buscarmos uma apropriação ponderada, cautelosa, cuidadosa, quanto mais nos dispersamos nas tentações da propaganda, e insensantemente buscamos o novo e o mais novo, e, desamparados, nos damos conta que a vida "é curta demais", que nunca vamos dar conta de ler tudo que deveríamos ler, ou de assistir tudo que deveríamos assistir, mais afastamos a angústia que sempre paira, como uma névoa, à espreita. No entanto, também não adianta nos isolarmos do mundo, do "barulho da cidade", para que tenhamos o silêncio do campo e lá fiquemos à espera da angústia, achando que ela certamente virá, que será só uma questão de tempo, dada nossa "autêntica" vida bucólica. O silêncio da fala que vem à palavra pela angústia, e que nada verbaliza, não tem nada de ôntico, ele pode se abater por sobre nós em uma metrópole, ao passo em que o campo talvez seja muito barulhento, dominado pela falação, mesmo que nenhuma pessoa esteja lá fisicamente falando. O silêncio é estranho, a fala é estranha, a consciência é estranha. Angustiado, o ser-aí fica abandonado a si-mesmo, ele "não tem para onde fugir". Só o que resta a ele é lidar consigo próprio. Daí ele tomar consciência de que também ele é estranho, e, por isso, absolutamente insubstituível.

Estranheza é, na verdade, o modo fundamental, mas encoberto, de ser-no-mundo. Enquanto consciência, é do fundo desse ser que o ser-aí apela. O "eu sou apelado" é uma fala privilegiada do ser-aí. Só o apelo sintonizado pela angústia possibilita que o ser-aí se projete para o seu poder-ser mais próprio. Compreendido existencialmente, o apelo da consciência é que anuncia (...): a estranheza posterga o ser-aí e ameaça a sua perdição no esquecimento de si mesmo ${ }^{39}$.

\footnotetext{
${ }^{38}$ Idem, ibidem, §57, pp. 355-356.

${ }^{39}$ Idem, ibidem, §57, pp. 356.
} 
Com efeito, o apelo é proveniente da estranheza, a estranheza da singularidade lançada é o onde do apelo ${ }^{40}$. Se o ser-aí, angustiado, desvela-se como estranho e se apercebe, assim, de que é o fundamento do apelo, o remetente e o destinatário do chamado a vir a ser si mesmo em sentido próprio, isso significa que ele sempre existe enquanto fundamento - que é nada - e a partir dele. Ou seja, o ser-aí é seu fundamento, ele é esse nada, e, por conseguinte, por não ser coisa alguma, mas possibilidade de ser, é ente lançado, e com isso se compreende a partir de possibilidades. "Isso implica, no entanto, que: podendo-ser, ele está sempre numa ou noutra possibilidade, ele constantemente não é uma ou outra e, no projeto existenciário, recusa uma ou outra"41. É por ontologicamente existirmos no sentido rigoroso do termo, isto é, já sempre sermos possibilidade de possibilidades, é que existenciariamente podemos fazer planos para nossas vidas, optarmos por tomar certas decisões em vez de outras. Por conta de já sempre ser esse nada é que o ente cujo ser é o cuidado é e está sempre em dívida, pois por ter sempre de partir desse fundamento que ele mesmo é, o ser-aí nunca poderá apoderar-se propriamente de si mesmo, dado que é sempre projeto lançado, já sempre "está correndo" o fluxo das suas possibilidades, e é isso justamente o que constitui a existência. Heidegger arremata:

O apelo é apelo do cuidado. O ser e estar em dívida constitui o ser que chamamos de cuidado. Na estranheza, o ser-aí se encontra originariamente reunido consigo mesmo. A estranheza coloca esse ente diante de seu nada inconfundível, o qual pertence à possibilidade de seu poder-ser mais próprio. $\mathrm{Na}$ medida em que, para o ser-aí enquanto cuidado, o que está em jogo é o seu ser, a partir da estranheza, ele faz apelo a si mesmo, enquanto faticamente decadente no impessoal, para assumir o seu poder-ser. A interpelação é uma reclamação apeladora: $a$-pelar a possibilidade de, em existindo, assumir, em si mesmo, o ente-lançado que é; re-clamar para o estar-lançado de modo a se compreender como fundamento do nada a ser assumido na existência. A reclamação apeladora da consciência oferece para o ser-aí a compreensão de que ele, na possibilidade de seu ser, é o fundamento nulo de seu projeto nulo, devendo recuperar-se para si mesmo da perdição no impessoal, ou seja, de que ele é e está em dívida ${ }^{42}$.

É pela disposição fundamental da angústia que o ser-aí compreende-se em toda a sua estranheza. Estando estranho, ele apercebe-se como sendo

\footnotetext{
${ }^{40}$ Cf. Idem, ibidem, $\$ 58$.

${ }^{41}$ Idem, ibidem, $\$ 58$, p. 365.

${ }^{42}$ Idem, ibidem, §58, p. 367.
} 
radicalmente estranho, o que o abre para sua singularidade. Desse modo, o barulho dispersivo do impessoal dá lugar ao silêncio da fala que o interpela a cuidar de seu projeto, fala essa que ele ausculta, no sentido de um ouvir concentrado, um ouvir a si mesmo, o clamor de seu próprio que busca vir à luz. Dispor-se para esse silêncio que articula a fala do cuidado é um querer-terconsciência, e essa disposição é a própria angústia. Por isso diz Heidegger que "o querer-ter-consciência transforma-se na prontidão para a angústia"43. O apelo da consciência sempre é silencioso, a estranheza silencia o ser-aí e permite a ele "aquietar-se na quietude de si-mesmo" "44. A estranheza, assim, torna manifesto o nada que o ser-aí é, uma compreensão de si velada pelo impessoal. O impessoal, de fato, faz com que o ser-aí se compreenda a si mesmo de muitas formas, mas nunca de modo tão radical como a compreensão propiciada pela estranheza. Entretanto, se a estranheza, como visto, marca a singularidade do ser-aí, e isso significa que o seu todo, compreendido como a estrutura do cuidado, é aberto, ou seja, o ser-aí, ontologicamente, nunca pode ser propriamente todo no sentido de uma completude de suas possibilidades, ele terá sempre que sacrificar possibilidades em prol de outras, é dizer, o ser-aí é e está, ontologicamente, sempre em débito, isso desvela que o caráter radical, fundamental do ser-aí, singularizado, ou seja, diante do seu próprio, é a finitude.

As possibilidades do ser-aí, embora sejam indeterminadas ontologicamente, ainda que determinadas historicamente, não são, pois, infinitas. Não se trata de uma questão quantitativa, no entanto. A análise da noção de cuidado como o ser do ser-aí revelou que a dívida existencial é ontologicamente fundante, é o que estabelece as bases da existência. Ser e estar em dívida significa que, pelo fato do ser-aí ser seu fundamento e dele precisar partir, ele já sempre e necessariamente precisa sacrificar possibilidades e se decidir por outras, isso enquanto projeto lançado na facticidade, que se reflete em nossas decisões existenciárias, corriqueiras, cotidianas. A dívida não é, em si mesma, nada de negativo, pois é justamente pelo fato de já sempre estarmos endividados que a existência é possível, a dívida é a fonte da liberdade enquanto o que possibilita nossas possibilidades. O próprio fato de podermos - e na maioria das vezes é isso o que ocorre - compreender a princípio a dívida como algo negativo, como culpa

\footnotetext{
${ }^{43}$ Idem, ibidem, §60, p. 377.

${ }^{44}$ Idem, ibidem, §60, p. 378.
} 
(Schuld, mesmo termo alemão que também pode traduzir “dívida”), já mostra uma tendência, uma vontade nossa de sermos infinitos, de não querermos sacrificar nenhuma possibilidade, não termos que abrir mão de nada potencialmente valoroso para nossas vidas. Se vemos a dívida como culpa, é porque "inconscientemente" já nos apercebemos como finitos, limitados. Sabemos que "não temos tempo" para fazer tudo o que poderíamos querer. E como sabemos disso? Porque temos a certeza que um dia "nosso tempo" acabará, pois morreremos.

Como podemos ter tal certeza? Empiricamente, não nos faltam evidências de que a morte é parte natural da vida. Plantas, animais e humanos cessam de viver a cada momento, e é impossível viver sem se deparar com experiências de perda. Que somos mortais e que todos morreremos um dia se apresenta como algo óbvio. Talvez a ilação mais famosa da história da lógica seja: "Todo homem é mortal. Ora, Sócrates é homem. Logo, Sócrates é mortal”. A premissa maior contém aquela verdade universal e patente a qualquer intelecto: todo homem é mortal. Nossa tendência é, pois, a de fazermos uma substituição mental, considerando-nos um ser humano em abstrato, e, dado que em nossa experiência todos os seres humanos morrem, seja lá por quais motivos, sabemos que um dia morreremos também, pois somos humanos tais como os incontáveis humanos que faleceram antes de nós. Ora, mas se pensarmos o ser-aí em sua estranheza, face à sua singularidade, ou seja, diante da constatação de que ele é insubstituível, a certeza ôntica da morte deixa de ser tão óbvia assim. A certeza ôntica, empírica, de que somos mortais, de que nossa vida terrena há de cessar mais cedo ou mais tarde, não nos ajuda a pensar a questão da morte em uma perspectiva ontológico-existencial ${ }^{45}$. E isso porque a acepção banal da morte como fim da vida acarreta uma carga negativa, impotente, lamentável.

Ontologicamente, a morte é um dado positivo da existência. Só os entes existentes, isto é, dotados de ser-aí, morrem, propriamente falando. Existência, naturalmente, entendida no sentido próprio que Heidegger a dá, e não como a existentia metafísica, o ente efetivo, presente à vista. Isso significa que, rigorosamente, só o ser humano morre. Objetar-se-á que as plantas e os animais

\footnotetext{
${ }^{45}$ Cf. HEIDEGGER, Ser e tempo, §46ss., onde ele aponta as diversas insuficiências da concepção ôntica de morte e discute-as mais pormenorizadamente.
} 
também morrem, pois são seres vivos. Não. Morte aqui não significa, já que falamos a partir de uma perspectiva ontológico-existencial, o mero cessar de viver. Não estamos tomando o homem aqui como um ente dotado de vida, mera vida. Homem aqui, a humanidade do humano, é o fato de, ontologicamente, ele ser compreensão de ser, e isso é a existência. Só esse ente, visto sob essa perspectiva, existe e, consequentemente, morre. Essa concepção positiva da morte diz, pois, aquilo que já vinha sendo dito: que o ser-aí é singular e, enquanto tal, já sempre está em dívida. A morte significa que o ser-aí, tomado em seu todo enquanto cuidado, sempre terá pendências existenciais, dado que ele sempre precede a si próprio em seu projeto lançado e deve, pois, ser suas possibilidades, e o modo de assumi-las propriamente é o da dívida. A singularidade do ser-aí se expressa no fato de a morte ser única, própria, intransferível. A morte, ao mesmo tempo, define o ser-aí ontologicamente como singular e finito.

De todas as possibilidades próprias do ser-aí, a morte é a única certa, ou seja, é a única que, independentemente da configuração histórica em que o ser-aí se encontre jogado, será uma possibilidade certa. Mas ser a mais certa não é a única peculiaridade da morte. Ela é a possibilidade da impossibilidade, já que ela significa o fim do "aí” do ser-aí. Se o ser-aí sempre já é o seu "aí", a morte é o não-ser do ser-aí. Contudo, se propriamente o modo de ser do ser-aí é assumir o seu poder-ser mais próprio, e isso se dá, já que o ser-aí é ek-stático, como um perene anteceder-se a si, e isso como um projetar, e se a morte é a sua possibilidade mais própria e a única certa, toda decisão autêntica do ser-aí passa por uma antecipação da morte. Isso não significa que o ser-aí, querendo ser autêntico, deva ficar ônticamente pensando na morte, vivendo cada dia como se fosse último, entregue ao mantra deturpado do carpe diem. Significa que tudo aquilo que vinha sendo dito, de que, apercebendo-se estranho, o ser-aí encontra-se em meio ao silêncio que permite que ele seja interpelado pela consciência, que clama para que ele cesse a fuga de si e assuma seu projeto, suas possibilidades próprias, e que isso evidencia ao ser-aí seu caráter singular e insubstituível, tudo isso só é possível graças à morte enquanto o sentido do cuidado, e, por conseguinte, como o sentido da possibilidade do ser-aí ser todo em sentido próprio. 
A antecipação da morte, ser-para-a-morte (Sein-zum-Tode), dá sentido ao cuidado, dá sentido ao projeto, e assim propicia a singularização, na medida em que é a razão da consciência do próprio do ser-aí. Em toda a decisão autêntica, sempre já se é para sua morte, já se antecipou a possibilidade da morte como condição de possibilidade de todas as demais possibilidades. Abrir-se para simesmo, no sentido de arrancar o seu próprio do velamento do impessoal, é sempre um nascer e um morrer, um desvelar que vela, um desencobrir que encobre. Sempre antecipar a possibilidade da morte como requisito para as demais possibilidades é sempre, autenticamente, pôr-se diante do nada, já que a morte é o radical não-ser do ser-aí. Ora, foi visto que este pôr-se diante do nada não depende de nossa vontade, mas é consequência daquela disposição fundamental, a angústia, que, suspendendo nosso ser-no-mundo, dá o seu sentido enquanto tal. Desse modo, Heidegger diz:

A angústia, porém, é a disposição que permite que se mantenha
aberta a ameaça absoluta e insistente de si mesmo, que emerge
do ser mais próprio e singular do ser-aí. Na angústia, o ser-aí
dispõe-se frente ao nada da possível impossibilidade de sua
existência. A angústia se angustia pelo poder-ser daquele ente
assim determinado, abrindo-lhe a possibilidade mais extrema.
Porque o antecipar simplesmente singulariza o ser-aí e, nessa
singularização, torna certa a totalidade de seu poder-ser, a
disposição fundamental da angústia pertence ao compreender de
si mesmo, próprio do ser-aí. O ser-para-a-morte é,
essencialmente, angústia ${ }^{46}$. Ser-para-a-morte é a coragem de saltar para o abismo, é a prontidão para a angústia, sendo nesse sentido que Heidegger pode dizer que, essencialmente, ser-para-a-morte é angústia, pois é um pôr-se e um dispor-se ante o abissal nada que é o mundo a partir do nada que é o fundamento que nós mesmos já sempre somos. Ser-para-a-morte não significa um desprendimento do mundo, não é um sair do mundo, mas sim a dissipação das ilusões do impessoal, o desvelar de tudo que temos de próprio e que era velado pela cotidianidade.

A insignificância do mundo, aberta na angústia, desvela a nulidade das ocupações, a impossibilidade de projetar-se um poder-ser da existência primariamente fundado na ocupação. Desvelar essa impossibilidade significa, porém, deixar vir à luz a possibilidade de um poder-ser próprio ${ }^{47}$.

\footnotetext{
${ }^{46}$ HEIDEGGER, Ser e tempo, $\$ 53$, p. 343, grifo nosso.

${ }^{47}$ Idem, ibidem, §68, p. 430.
} 
Somente assim somos levados à decisão, decisão para o agir. Agir aqui não significa qualquer ação ôntica, no sentido em que qualquer lida com os entes é uma ação, qualquer comportamento ante as estruturas da facticidade é uma ação. São de fato ações, mas não as que vêm ao caso aqui. Heidegger inicia mesmo sua famosa Carta sobre o humanismo dizendo:

Nós ainda estamos muito longe de pensar a essência do agir de maneira suficientemente decisiva. Só conhecemos o agir como produção de um efeito, cuja realidade vem estimada segundo sua utilidade. Mas a essência do agir é o levar a cabo. Levar a cabo significa: desenvolver alguma coisa na plenitude de sua essência, conduzir até essa essência ${ }^{48}$.

Agir é consumar, levar uma essência à sua plenitude. A essência do ser-aí é a sua existência, cujo todo é abarcado pela estrutura do cuidado. Levar a cabo essa essência, a existência, outra coisa não quer dizer que liberar o seu próprio, tomar consciência pelo clamor da fala que nos interpela a assumirmos a responsabilidade pelo nosso projeto lançado, assumirmos nossas possibilidades próprias, cessarmos a fuga de nós mesmos no cômodo e familiar convívio da cotidianidade impessoal e tomarmos a decisão por nós próprios. Decisão, em alemão, é Entschlossenheit, onde o prefixo Ent-, como já visto - e não à toa - em Entwurf, projeto, denota negação, um movimento em sentido contrário, "nadar contra a corrente". O verbo schliessen significa fechar, trancar. A decisão é, pois, um lutar contra o fechamento, um agônico esforço para rasgar o impessoal, enfrentar o velamento e libertar o seu próprio. O impessoal é a indecisão. Ele nos dispersa, impede que nos tomemos como singulares, unos. "A decisão antecipadora (...) é o compreender que responde ao apelo da consciência, a qual libera a possibilidade de a morte apoderar-se da existência do ser-aí e de, no fundo, dissipar todo encobrimento de si mesmo por menor que seja” ${ }^{\natural 9}$.

A decisão é um modo privilegiado de abertura do ser-aí. Decidir-se pelo seu próprio é o agir criador. A decisão por tornar-se quem é, ou seja, por assumir seu próprio, é o acontecimento da verdade. A decisão é verdade originária ${ }^{50}$. Por ser criadora, a arte, enquanto o pôr-em-obra da verdade ${ }^{51}$, é exemplar. Sejamos, pois, os artistas de nós próprios, que nossa existência desvele-se como uma obra

\footnotetext{
${ }^{48}$ HEIDEGGER, Carta sobre o humanismo. In:

${ }^{49}$ HEIDEGGER, Ser e tempo, §62, p. 393.

${ }^{50}$ Cf. HEIDEGGER, Ser e tempo, §62, p. 390ss

${ }^{51} \mathrm{Cf}$. HEIDEGGER, A origem da obra de arte. . Marcas do caminho, p. 326.
} 
de arte. Nossa vida fática nos foi dada, e quanto a isso não decidimos. Nossa existência, por outro lado, é criação nossa. Criar para além de si, transcender-se.

E assim falou Zaratustra ao povo: É tempo de o homem fixar sua meta. É tempo de o homem plantar o germe de sua mais alta esperança. Seu solo ainda é rico o bastante para isso. Mas um dia este solo será pobre e manso, e nenhuma árvore alta poderá nele crescer. Ai de nós! Aproxima-se o tempo em que o homem já não lança a flecha de seu anseio por cima do homem, e em que a corda do seu arco desaprendeu de vibrar! Eu vos digo: é preciso ter ainda caos dentro de si, para poder dar à luz uma estrela dançante. Eu vos digo: tendes ainda caos dentro de vós. Ai de nós! Aproxima-se o tempo em que o homem já não dará à luz nenhuma estrela ${ }^{52}$.

O tempo desse homem que não cria para além de si, do homem que parece ser incapaz de sustentar o fardo dessa tarefa, é o que grosseiramente vimos como o tempo do niilismo, que desemboca no que Heidegger chamará de era da técnica. Nesse sentido, precisamos nos confrontar com a determinação histórica real em que nos encontramos neste momento. A analítica existencial de Ser e tempo estabelece o arcabouço, o fundamento e, por conseguinte, o princípio de qualquer pensamento que vise se desprender das amarras da metafísica, de modo a superá-la, tal como Heidegger compreende este termo. Mas, justamente, por ter esse caráter mais "genérico", Ser e tempo ainda não deixa de ser, nesse sentido, "metafísico". Tampouco significa que ele deve ser ignorado, ou que Heidegger o deixou de lado em prol de outras questões. Importa agora, pois, percebermos o porquê de Heidegger ter deixado incompleto o projeto da obra Ser e tempo, e em que sentido tal obra, ainda assim, permeia e perpassa todos os caminhos pensantes de Heidegger após essa virada em seu pensamento.

\footnotetext{
${ }^{52}$ NIETZSCHE, Assim falou Zaratustra, Prólogo, 5, p. 18.
} 


\section{Verdade, espanto e técnica}

Em febre e olhando os motores como a uma Natureza tropical -/Grandes trópicos humanos de ferro e fogo e força -/Canto, e canto o presente, e também o passado e o futuro/Porque o presente é todo o passado e todo o futuro/E há Platão e Virgílio dentro das máquinas e das luzes eléctricas ${ }^{1}$.

Álvaro de Campos

Heidegger propôs um sumário da obra Ser e tempo, atestado no §8, que nunca chegou a ser cumprido e realizado. O projeto da obra como um todo consistiria de duas partes, cada uma com três seções. Apenas as duas primeiras seções da primeira parte foram publicadas, em 1927. Heidegger faleceu em 1976. Nesse ínterim de 49 anos não houve nenhum esboço de retomada da obra, o projeto havia sido concluído tal como se encontrava. Estariam as considerações de Ser e tempo equivocadas? Teria Heidegger se dado conta que havia "embarcado em uma canoa furada"? Não, e isso atesta-se pelo fato de que toda a produção posterior dele, de um modo ou de outro, faça referência a Ser e tempo, ao horizonte conquistado por aquela obra de pensamento - obra pensante -, mesmo que tácita ou indiretamente. Por que, então, abrir mão de uma obra tão seminal e determinante para seu pensamento?

A questão diretriz de Ser e tempo concerne ao sentido de ser. A pergunta pelo ser havia caído em esquecimento. Esse esquecimento se deu não por uma falta de interesse, pois temos toda a milenar história da metafísica como comprovante de que o significado de ser foi buscado constantemente. No entanto, o questionar da metafísica pelo ser é justamente o que lançou o ser no esquecimento. A metafísica, pretendendo se apropriar do ser a partir de uma compreensão racional, já sempre compreendia o ser a partir do ente. $\mathrm{O}$ ente era a medida, o critério e a origem da pergunta pelo ser. Ser, nesse caso, significa: ser do ente, a entidade do ente, o que faz o ente ser ente. Não é sob essa perspectiva que Heidegger compreende a noção de diferença ontológica. Caso assim fosse,

\footnotetext{
${ }^{1}$ PESSOA, Poesia completa de Álvaro de Campos, p. 78.
} 
ele, ao afirmar que o ser havia caído em esquecimento, estaria advogando uma tolice evidente, já que todo pensador distingue ser e ente de alguma forma. Mas essa distinção foi por todos concebida como essentia e existentia, ou o ser como summum ens e e os demais entes como ens creatum.

Não está em jogo, para Heidegger, questionar o ser entendido como causa, princípio, razão e fundamento do ente. Imersos já nessas pré-compreensões e preconceitos acerca do ser, nem mesmo somos capazes de pôr a pergunta pelo ser enquanto tal. Ser e tempo é a tentativa de pôr esta questão. Para tanto, havia a necessidade de uma destruição da metafísica, no sentido, justamente, de erradicar, ou ao menos colocar entre parênteses, esses preconceitos que nos fazem tender a compreender o ser como ser do ente, a fim de que tenhamos clareza o suficiente para sermos dignos e capazes de questionar o ser em seu sentido próprio. Todavia, Heidegger se apercebeu que, mesmo com esse intuito, ele ainda encontrava-se preso às conceptualizações metafísicas, entranhado em seu método argumentativo, condicionado por sua linguagem. Superar a metafísica, de modo radical, deveria passar por uma nova apropriação da linguagem, deixar-se transformar por ela. Ser e tempo deu o primeiro e fundamental passo ao conceber a linguagem, originariamente, como a fala que silenciosamente interpela o ser-aí, chamando-o a assumir suas possibilidades próprias de ser. Mas o ser-aí enquanto ponto de partida para a pergunta pelo sentido de ser também deveria ser revisto. O ser-aí, sendo essencialmente compreensão de ser, é o ente apto, capaz de se questionar pelo ser, já que seu ôntico é ontológico. Por conta disso, a destruição da metafísica deveria partir de uma analítica existencial do ser-aí. Entretanto, isso limitou o sentido de ser ao horizonte ek-stático-transcendental de compreensão do ser-aí. O projeto de Ser e tempo, por conseguinte, mostrou-se insuficiente para dar conta da magnitude da tarefa que é a pergunta pelo ser, mesmo que tenha tido o mérito de estabelecer as bases para tal, além de ter lançado luz à urgência e necessidade de tal tarefa.

Considerando tudo isso, fica evidente que a obra Ser e tempo não é de modo algum irrelevante - não só para o pensamento heideggeriano como para a filosofia como um todo -, embora tenha seus problemas. É nesse contexto que Heidegger demarca a virada (Kehre) em seu pensamento. É digno de nota que os planos para essa viravolta constavam já no projeto de Ser e tempo, dado que o 
título da terceira seção da primeira parte é Tempo e ser. A virada já era um passo pretendido por Heidegger, não foi nada que o abateu repentinamente e que por isso ele decidiu "abandonar" o projeto de Ser e tempo. Acontece que essa virada não poderia se dar "dentro" dessa obra, dadas as categorias fenomenológicas que a marcam. De acordo com o próprio Heidegger:

Seguir e acompanhar de maneira suficiente a realização desse modo diferente de pensar, que abandona a subjetividade, fica entrementes dificultado pelo fato de, na publicação de Ser $e$ tempo, ter faltado a terceira seção da primeira parte. É aqui que o todo faz uma viragem. A seção problemática ficou de fora porque o pensamento fracassou em dizer de modo suficiente essa viragem e não conseguiu expressá-la com o auxílio da linguagem da metafísica ${ }^{2}$.

E ele continua:

A conferência $A$ essência da verdade, pensada e apresentada em 1930, mas que só foi publicada em 1943, permite de certo modo uma inserção do olhar no pensamento dessa viragem de "ser e tempo" para "tempo e ser". Essa viragem não é uma mudança do ponto de vista de Ser e tempo, mas nela o pensamento buscado alcançou pela primeira vez adentrar no sítio da dimensão a partir da qual Ser e tempo foi experimentado, e, em verdade, experimentado na experiência fundamental do esquecimento do $\operatorname{ser}^{3}$.

Segundo Heidegger, a conferência supracitada seria a primeira expressão da virada em seu pensamento. Há, de fato, nessa conferência, uma exortação de Heidegger para que estejamos dispostos a uma "transformação do pensamento" (Wandlung des Denkens) ${ }^{4}$. Em que sentido? Trata-se de uma conferência sobre a verdade. Mais: sobre a essência da verdade. Não parece haver nada mais metafísico do que questionar-se sobre a essência de algo, sobremaneira quando se trata da essência da verdade, um dos temas metafísicos por excelência. Levando isso em conta, como Heidegger espera que mudemos nosso modo de pensar, que estejamos dispostos para tal, quando ele mesmo parece repetir o mesmo linguajar metafísico? Ademais, o que poderia ser transformado, já que se trata da verdade? O que seja a verdade, todos, de um modo e de outro, já o sabem. Exigimos a verdade dos políticos, das autoridades, de nossa família, de nossos amigos, de pessoas próximas e queridas. Admiramos a honestidade, como também quem fala francamente, quem expressa a verdade "doa a quem doer". Odiamos a falsidade e

\footnotetext{
${ }^{2}$ HEIDEGGER, Carta sobre o humanismo. In:

${ }^{3}$ Idem, ibidem, pp. 340-341.

${ }^{4}$ Cf. HEIDEGGER, A essência da verdade. In: . Marcas do caminho, p. 340. . Marcas do caminho, §4, p. 199.
} 
a mentira, odiamos quando percebemos que fomos enganados. A verdade tem um valor. Esse valor é consentido por todos. Logo, sabemos o que ela, a verdade, seja, por mais que não saibamos definí-la ou expressá-la propriamente, pois não podemos valorizar aquilo que nos é indiferente ou que não fazemos a menor ideia do que seja, ou mesmo que exista.

Isso diz o nosso senso comum. Que dizem aqueles que se dedicam a estudar filosofia mais profundamente? Como se define a verdade, de modo formal, científico? Contemporaneamente, talvez a definição de verdade mais famosa e difundida seja a de Alfred Tarski. Tarski, de modo simples e preciso, busca uma definição satisfatória da verdade, no sentido de responder à questão acerca do que faz com que uma sentença seja verdadeira. Para tanto, segundo Tarski, a definição deve ser "materialmente adequada e formalmente correta", Ser formalmente correta significa que a definição deve ser precisa, livre de contradições e deve ter a forma correta, isto é, ser universal de modo a ser aplicável a quaisquer situações. Ademais, uma definição do que seja verdadeiro para as sentenças descritivas de uma linguagem L será materialmente adequada se e somente se tal definição implicar todas as equivalências da verdade, ou seja, todas as instâncias do esquema de verdade $\mathrm{T}$, onde “( $\mathrm{T})$ ' $\mathrm{P}$ ' é verdadeiro se, e somente se, $\mathrm{P}$ ", no qual o conteúdo de "P" possa ser substituido por qualquer sentença descritiva arbitrária da linguagem L. O exemplo clássico de Tarski é: “A sentença 'a neve é branca' é verdadeira se, e somente se, a neve é branca"7.

Essa definição semântica da verdade, citada aqui apenas em sua formulação coloquial e, do ponto de vista dos estudos mais aprofundados da lógica, insuficiente ${ }^{8}$, ecoa formulações clássicas da história do pensamento ocidental. Aristóteles havia definido o ser verdadeiro como "dizer que o ser é e que o não-ser não é", ao passo que o falso "é dizer que o ser não é ou que o nãoser é" ${ }^{\circ}$. Tomás de Aquino aprofunda essa ideia formulando sua definição nominal

\footnotetext{
${ }^{5}$ TARSKI, A concepção semântica da verdade, p. 20.

${ }^{6}$ Essa formulação ainda pode ser mais generalizada, segundo Tarski (Op. cit., p. 26), como "Para todo x, x é uma sentença verdadeira se e somente se, para um certo $\mathrm{p}$, x é idêntica a 'p', e p."

${ }^{7}$ Idem, ibidem, p. 161.

${ }^{8}$ Isso segundo o próprio Tarski, que diz (Op. cit., p. 21): "Nessa linguagem [a coloquial], parece impossível definir a noção de verdade e até mesmo aplicar tal noção de maneira consistente e concordante com as leis da lógica". Para as definições mais complexas, Cf. TARSKI, Op. cit., p. 33 ss.

${ }^{9}$ ARISTÓTELES, Metafisica $\Gamma 71011 \mathrm{~b}$ 25-27.
} 
de verdade do seguinte modo: "veritas est adaequatio rei et intellectus" a verdade é adequação de coisa e intelecto. Em ambas essas formulações está pressuposta a noção de que a verdade encontra-se primariamente no intelecto ${ }^{11}$, que, ao unir ou separar conceitos, ou seja, formular juízos, pode posteriormente adequar tais juízos ao real. Caso se adequem, a proposição é verdadeira. Logo, a verdade é uma propriedade dos juízos, das proposições. A mesma concepção atravessa também a modernidade, tal como nos atesta Descartes, que afirma: "propriamente, a verdade e o erro só podem existir no entendimento"12. Hume, de modo semelhante, diz: "A verdade e o erro consistem no acordo ou desacordo quer com as relações reais de ideias, quer com a existência e os factos reais"13. Também Kant expressa que "a definição nominal do que seja a verdade, que consiste na concordância do conhecimento com o seu objeto, admitimo-la e pressupomo-la aqui"14. Por fim, Nietzsche diz: "Verdade é o tipo de erro sem o qual uma espécie de seres vivos não poderia viver. O valor para a vida decide em última instância"15. Quanto ao dito de Nietzsche, Heidegger assevera:

Se para Nietzsche a verdade é um tipo de erro, então sua essência reside em um modo de pensar que necessariamente falsifica a cada vez o real, na medida em que toda representação paralisa o "devir" incessante e, assim, com esse devir paralisado, apresenta como suposto real, frente ao "devir" fluente, um algo não correspondente, isto é, incorreto e, com isto, errôneo ${ }^{16}$.

Mesmo que Nietzsche, no fim da metafísica, critique o conceito corrente de verdade, ele ainda assim reflete a concepção de verdade como retidão, dado que, pelo fato, para ele, de a verdade ser uma "cristalização" daquilo que sempre flui, do perene devir que é a própria realidade, nunca há uma adequação entre aquilo tido como verdade e o real, pois o real nunca "é", está sempre "vindo-aser” e, por conseguinte, a verdade é um “erro", já que não se adequa à realidade. Ou seja, por toda a história da metafísica, a verdade foi compreendida, grosso modo, da mesma forma, ao menos essencialmente do mesmo modo. Para Heidegger, foi justamente o início dessa concepção de verdade que demarcou o

\footnotetext{
${ }^{10}$ TOMÁS DE AQUINO, De Veritate, q. 1, a. 1, resp.

${ }^{11}$ Cf. ARISTÓTELES, Metafísica E 4 1027b 25ss.; TOMÁS DE AQUINO, De Veritate, q. 1, a. 2.

${ }^{12}$ DESCARTES, Regras para a direção do espírito, Regra VIII, p. 48.

${ }^{13}$ HUME, Tratado da natureza humana, III, i, 1, p. 530.

${ }^{14}$ KANT, Crítica da razão pura, A58/B82.

${ }^{15}$ NIETZSCHE, Vontade de poder, §493, p. 264.

${ }^{16}$ HEIDEGGER, A teoria platônica da verdade. In: Marcas do caminho, p. 245.
} 
nascimento da metafísica. Isso se deu com Platão. Heidegger nota que na Alegoria da Caverna, apresentada por Platão no Livro VII da República, encontra-se a apresentação da teoria platônica da verdade, que determinou o curso da história do ocidente. A conclusão de Heidegger da interpretação da Alegoria é que, em Platão, testemunhamos uma mudança da essência da verdade.

Se, no geral, em toda e qualquer postura frente ao ente, está em

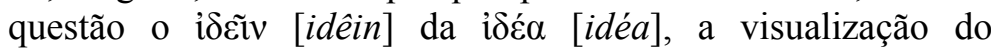
"aspecto", então todo esforço deve concentrar-se antes de tudo em procurar possibilitar uma tal visualização. Para isto, é necessário um olhar reto. Já aquele mesmo que foi liberto no interior da caverna, ao afastar-se das sombras e voltar-se para as coisas, precisa voltar seu olhar para aquilo que é "mais ente" do que as meras sombras (...). A transição de uma situação para a outra consiste em tornar o olhar mais reto. Tudo depende da ỏ $\theta$ ótns [orthótes], da retidão do olhar. (...) Em consequência

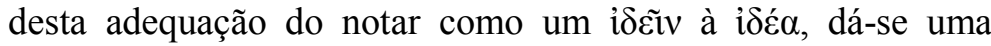

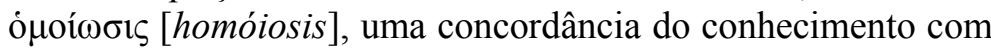
a coisa mesma. (...) Assim, (...) verdade torna-se ỏ $\rho$ ót $\eta$ s, retidão do notar e enunciar ${ }^{17}$.

Ora, se com Platão há uma mudança na concepção da essência da

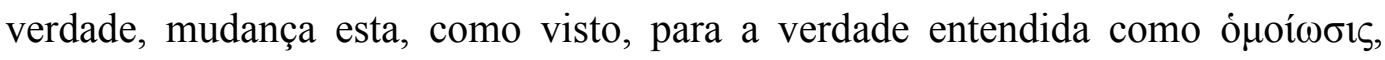
adequação entre intelecto e coisa, derivado da ỏ $\rho \theta$ ó $\eta \varsigma$, da retidão ou correção do olhar, da percepção, que perpassa toda a história da metafísica, isso significa, naturalmente, que havia uma concepção anterior, que sofreu tal modificação. Ela se expressa no próprio termo grego que traduzimos por veritas, verdade. O termo é à $\lambda \hat{\theta} \theta \varepsilon ı$ (alétheia). Embora, como vimos, o termo verdade seja entendido positivamente por nosso senso comum, o termo grego que designa a verdade, $\dot{\alpha} \lambda \hat{n} \theta \varepsilon ı \alpha$, é negativo, dado que o alfa presente no início do termo é privativo. 'A $\lambda \eta \dot{\theta} \varepsilon \varepsilon \alpha$, portanto, diz " $a$-létheia" o "não-lethé". Em grego, $\lambda \eta \dot{\theta} \theta \eta$ (léthe) significa esquecimento. Este termo é derivado do índo-europeu *leh-, que significa esconder, ocultar, e que curiosamente deu origem ao nosso termo letargia (do latim lethargia). A verdade, em sua concepção originária grega, diz, portanto: não-esquecimento, não-ocultamento, e, em sentido derivado, um romper com a letargia. Quando Heidegger diz, em Ser e tempo, conforme explicitado no capítulo anterior, que a decisão do ser-aí por seu próprio decorrente da angústia é a verdade originária, entendermos $\dot{\alpha} \lambda \hat{\eta} \theta \varepsilon ı \alpha$ como o rompimento da letargia típica do

${ }^{17}$ Idem, ibidem, p. 242. 
impessoal, propiciada pela estranheza, é fundamental. Esse é um dos sentidos fulcrais da verdade entendida como desvelamento. Ademais,

Se traduzirmos a palavra $\dot{\alpha} \lambda \dot{\eta} \theta \varepsilon \iota \alpha$ por "desvelamento", em lugar de "verdade", essa tradução não é somente mais "literal", mas ela compreende a indicação de repensar mais originariamente a noção corrente de verdade como conformidade do enunciado, no sentido, ainda incompreendido, do caráter do ser desvelado e do desvelamento do ente ${ }^{18}$.

A transformação do pensamento que Heidegger havia exortado anteriormente é a de sermos capazes de voltarmos a pensar a verdade como desvelamento, e não como correção ou adequação. A verdade entendida como adequação é uma concepção correta. Falar em concepção correta já pressupõe correção. Para o seu próprio critério pressuposto, a definição de verdade como adequação é correta. Ela prova e comprova seu próprio critério. Heidegger defende, contudo, que ela é posterior, dado que se deu como fruto da concepção platônica que modificou a compreensão de $\dot{\alpha} \lambda \hat{\eta} \theta \varepsilon ı \alpha$, entendida originariamente como desvelamento, para a $\dot{\alpha} \lambda \eta \dot{\theta} \theta \varepsilon 1 \alpha$ entendida como ó $\mu$ oí $\omega \sigma ı \varsigma$. Essa concepção de verdade é, pois, derivada, e, portanto, não é originária, ainda que seja correta. De modo essencial e originário, como visto, a verdade é desvelamento. Que significa isso?

Ser e tempo mostra que o homem, enquanto ente dotado de ser-aí, é essencialmente compreensão de ser. Em sua lida com os entes intramundanos, o ser-aí já sempre os compreendeu de algum modo. Essa compreensão se dá em conjunto com uma disposição de ânimo, que abre o mundo do ser-aí e o afina para com as coisas de algum modo. Essa abertura do mundo define o horizonte de sentido do ser-aí, e, portanto, da sua interpretação das coisas. Toda lida com os entes é, pois, um comportamento (Verhalten), um pôr-se dis-posto ante o mundo. Nesse sentido, Heidegger diz, em sua conferência $A$ essência da verdade, a polêmica frase: "A abertura que mantém o comportamento, como aquilo que torna intrinsecamente possível a conformidade, se funda na liberdade. A essência da verdade é a liberdade" ${ }^{\prime 1}$. Isso quer dizer: o desvelamento, em sua essência, é a liberdade. Quanto à liberdade, Heidegger dirá em uma outra conferência, também proferida em 1930:

\footnotetext{
${ }^{18}$ HEIDEGGER, $A$ essência da verdade. In:

${ }^{19}$ Idem, ibidem, p. 198. Marcas do caminho, pp. 200-201.
} 
Mas se a liberdade tem de ser buscada como fundamento da possibilidade do ser-aí, então ela mesma é em sua essência mais originária do que o homem. O homem não é senão um administrador da liberdade, só alguém que pode deixar ser a liberdade do que é livre da maneira que lhe cabe (...). A liberdade humana não significa mais agora: liberdade como propriedade do homem, mas, ao contrário, o homem é que se mostra como uma possibilidade da liberdade ${ }^{20}$.

A liberdade, enquanto essência da verdade entendida como desvelamento, é também o fundamento da possibilidade do ser-aí. Heidegger usa uma expressão estranha, a de que "o homem não é senão um administrador (Verwalter) da liberdade". Administrador pode significar um gestor, alguém incumbido por gerir algo a ele delegado. Pode-se compreender também alguém que cuida, mantém, mas com autoridade para tal. Essa citação parece evocar aquela, já anteriormente citada, de que o homem é o "pastor do ser". Seria coincidência? Ou o que está em jogo aqui é, justamente, compreendermos a liberdade como sendo o próprio ser? Sendo este o caso, fica mais claro o porquê da liberdade, isto é, o ser, ser ao mesmo tempo a essência da verdade e o fundamento da possibilidade do ser-aí. Não a toa, o ser-aí é sempre possibilidade de ser. A decisão do ser-aí por assumir seu poder-ser em sentido próprio é a verdade originária. Há, com efeito, uma copertinência radical entre ser, verdade e liberdade.

\begin{abstract}
A liberdade em face do que se manifesta no interior do aberto deixa que cada ente seja o ente que ele é. A liberdade revela-se, então, como o deixar-ser o ente (...).A palavra aqui necessária para expressar o deixar-ser do ente não visa, entretanto, nem uma omissão nem uma indiferença, mas o contrário delas. Deixar-ser significa entregar-se ao ente ${ }^{21}$.
\end{abstract}

O ser, compreendido enquanto liberdade, é o deixar-ser (lassen) o ente. Nesse sentido, o ser se dá, e a espontânea gratuidade do ser é a abertura desveladora dos entes, ao passo que o ser mesmo se retrai, pois ele mesmo nunca se revela enquanto tal. A gratuidade da doação do ser é a entrega ao ente. É essa a condição de possibilidade de todo comportamento do ser-aí para com os entes. O ser-aí move-se em meio ao deixar-ser do ente já aberto, isto é, disponível. O ser-aí abre-se para o ente no sentido de uma aptidão para ser tocado e tomado por ele, que já se encontra manifesto em sua disponibilidade, e, portanto, já compreendido

\footnotetext{
${ }^{20}$ HEIDEGGER, A essência da liberdade humana: introdução à filosofia, p. 163.

${ }^{21}$ HEIDEGGER, A essência da verdade. In:___. Marcas do caminho, p. 200.
} 
e interpretado. Essa aptidão da abertura do ser-aí é marcada pela afinação propiciada pela disposição. "O deixar-ser o ente marcado pelo caráter afinador penetra e precede todo o comportamento aberto que nele se desenvolve" ${ }^{, 22}$. Mas esse dispor-se para com o ente, que permite o comportamento, ao mesmo tempo que desvela os entes de algum modo, já que os lança na clareira, implica ao mesmo tempo um velamento do ente na totalidade. Totalidade não entendida como uma soma dos entes individuais em um todo, mas sim ser todo no sentido de plenitude, o ente tomado em todo o seu vigor essencial, $\kappa \alpha \theta^{\prime} \alpha v ่ \tau o ́ ~(k a t h ' a u t o ́)$, isto é, o ente em si mesmo no sentido de o ente por excelência.

Ainda que o homem se relacione constantemente com o ente em seu comportamento, ele se limita, contudo, habitualmente a este ou àquele ente em seu respectivo caráter manifesto. $\mathrm{O}$ homem limita-se à realidade corrente e passível de ser dominada, mesmo ali onde se tem de decidir o que é primeiro e o que é derradeiro. (...) Instalar-se na vida corrente é em si mesmo, porém, não deixar imperar o encobrimento do que está velado. (...) Lá onde o velamento do ente na totalidade só é tolerado sob a forma de um limite que acidentalmente se anuncia, o encobrimento como um acontecimento fundamental cai no esquecimento $^{23}$.

O ser-aí, jogado na cotidianidade histórica, marcado positivamente pelo impessoal, pode não deixar o ente ser tal como ele é. $O$ fato da essência da verdade ser a liberdade implica na possibilidade de uma dissimulação e encobrimento do ente ${ }^{24}$. Trata-se do domínio da aparência. Por isso Heidegger pôde comparar o senso comum, que impera no impessoal, com a sofística. Mas aparência aqui não é no sentido platônico de erro ou falsidade, mera cópia ou sombra das ideias, entendidas como ser ou essência das coisas. Aparência aqui deve ser entendida no sentido da manifestação dos entes numa perspectiva de domínio, domínio que condiciona a compreensão e interpretação, isto é, a possibilidade de comportamento para com os entes. $\mathrm{O}$ impessoal, enquanto domínio da aparência, no sentido acima, faz surgir a não-essência da verdade. Note-se: não-essência da verdade, e não erro ou falsidade. Se a verdade, essencialmente, é desvelamento, sua não-essência é o velamento. $O$ velamento não é negativo; ao contrário, ele é essencial. O velamento é anterior ao desvelamento, ele é a condição da possibilidade do desvelamento. Nesse sentido,

\footnotetext{
${ }^{22}$ Idem, ibidem, p. 204.

${ }^{23}$ Idem, ibidem, p. 207.

${ }^{24}$ Idem, ibidem, p. 203.
} 
o velamento é o próprio ser que, doando-se, isto é, desvelando-se, já sempre se retrai, se vela, se oculta. A esse velamento originário do ser, Heidegger dá o nome de mistério (Geheimnis).

O impessoal, no entanto, embora faça surgir o velamento do ente na totalidade, não deixa que ele impere. Sendo próprio do impessoal o domínio da aparência, ele é a própria clareira, cuja luz permite e condiciona a lida com o ente, é dizer, ela força a lida com o ente, no sentido de o pôr em evidência. O velamento, o mistério do ser, é, assim, esquecido. A transformação do pensamento evocada por Heidegger é a chamada de atenção para a urgência da meditação sobre o esquecimento do ser, isto é, de pensarmos a não-essência da verdade como o mais originário de sua essência. Transformarmos a essência da verdade na verdade da essência. E qual é a verdade da essência? Que o mais essencial é o velamento. Esquecimento do ser, portanto, não é perguntarmos simplesmente pelo ser. Vimos que toda a história da metafísica foi marcada pela pergunta acerca do ser. Mas a metafísica, perguntando pelo ser a partir do ente, entendendo-o como ser do ente, já sempre partiu e se manteve na aparência da evidencialidade do ente, fechando-se para o mistério. Esquecimento do ser, em seu sentido mais essencial, é o esquecimento de que o ser é esquecimento. A virada do pensamento heideggeriano é partir não do ser-aí, que já sempre encontra-se sob a égide da aparência e apenas a partir da estranheza pode superá-la, para partir do próprio ser, enquanto o acontecimento da verdade, que se dá na história.

\begin{abstract}
A ek-sistência do homem histórico começa naquele instante em que o primeiro pensador é tocado pelo desvelamento do ente e se pergunta o que é o ente. Nesta pergunta, experimenta-se pela primeira vez o desvelamento. (...) Somente onde o próprio ente é expressamente elevado e mantido em seu desvelamento, somente lá onde tal sustentação é compreendida à luz de uma pergunta pelo ente enquanto tal, começa a história ${ }^{25}$.
\end{abstract}

A história da qual Heidegger faz referência aqui não é aquela ensinada nas escolas que surge com o advento da escrita, e o homem aqui em questão também não é o "elo perdido" entre os hominídeos ancestrais e os humanos modernos. Que história é essa e que homem é esse que surgem concomitantemente? Heidegger parece estar nos dizendo que o início da filosofia, isto é, a primeira experiência do desvelamento do ser e a consequente pergunta

${ }^{25}$ HEIDEGGER, A essência da verdade. In: Marcas do caminho, pp. 201-202, grifo nosso. 
pelo ser do ente, é, ao mesmo tempo, o início da história e o surgimento do homem. Há uma unidade entre a filosofia - entendida como a pergunta pelo ser do ente -, história e homem. E qual seria o início da filosofia, já que a pergunta pelo ser é o princípio definidor da história?

Temos o testemunho, fundamentado na autoridade dos dois pensadores mais influentes da história da metafísica, Platão e Aristóteles, quanto ao princípio da filosofia e do filosofar. Ambos concordam quanto a este princípio. Não se trata de nenhuma data, nenhum marco cronológico. Tanto Platão quanto Aristóteles nos dizem: a filosofia nasce desde um e a partir de um $\pi \alpha ́ \theta$ os (páthos), isto é, de uma

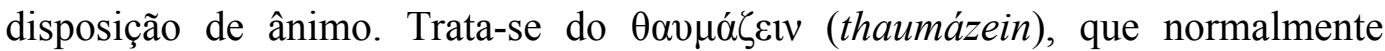
traduz-se por espanto, mas cuja polissemia dificilmente pode ser esgotada em apenas um termo, podendo significar também maravilhamento, admiração, reverência, incredulidade, deslumbramento etc. Ouçamos o testemunho desses pensadores. Platão assim o expressa:

Teet. Pelos deuses, Sócrates, como me espanto muitíssimo

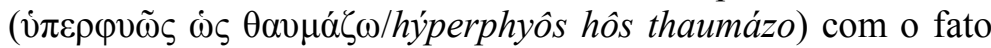
de ser assim e, por vezes, quando verdadeiramente olho $(\dot{\alpha} \lambda \eta \theta \tilde{\omega} \varsigma \quad \beta \lambda \varepsilon \dot{\pi} \omega v / a l e t h o ̂ s$ blépon) para isso, fico tonto

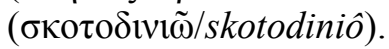

S. Efetivamente, meu amigo, Teodoro parece não ter adivinhado mal a tua natureza. Pois o que estás a passar

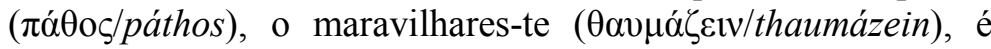
mais de um filósofo. De fato, não há outro princípio da filosofia

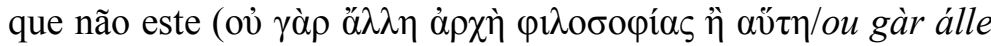
arkhè philosophías è áute), e parece que aquele que disse que

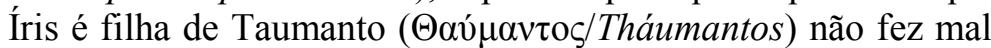
a genealogia ${ }^{26}$.

Há nesta breve passagem a abertura de inúmeros caminhos, como é costumeiro nos textos platônicos. Comecemos o nosso trilhar pelo fim da fala de Teeteto, com a ressalva de que faremos uma apropriação descontextualizada, violenta, da passagem supracitada. Teeteto afirma que fica tonto, sente vertigem, quando verdadeiramente olha para aquilo que o espanta deveras. Que nos diz tal

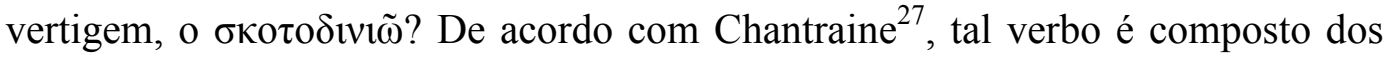

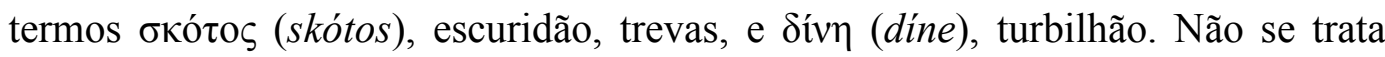
apenas de uma tontura derivada de giros a esmo, mas sim de um girar perdido no

\footnotetext{
${ }^{26}$ PLATÃO, Teeteto, $155 \mathrm{c}-\mathrm{d}$.

${ }^{27}$ CHANTRAINE, Dictionnaire Étymologique de la Langue Grecque, p. 1022.
} 
escuro, perder-se num vórtice tenebroso. Teeteto não se sente assim sempre, mas apenas quando verdadeiramente olha para o espantoso.

O verbo usado por Platão para tal olhar é $\beta \lambda \varepsilon ́ \pi \omega$ (blépo). Bruno Snell cita ao menos dez verbos diferentes empregados por Homero para designar o ato de $\operatorname{ver}^{28}$. Destes, vários caíram em desuso na prosa, na língua viva, e foram substituídos por duas novas palavras. Uma delas é $\beta \lambda \varepsilon ́ \pi \varepsilon ı v$ (blépein). Trata-se de um verbo não presente em Homero. Segundo Snell, essa palavra substitui o verbo arcaico $\delta \varepsilon ́ \rho \kappa \varepsilon \sigma \theta \alpha \mathrm{l}$ (dérkesthai) que designava não qualquer visão, mas um olhar penetrante, agudo, um voltar-se para... atento e compenetrado. Snell adiciona: "Nós, alemães, podemos traduzir a contento esse significado com a palavra blicken. Blicken significa originariamente 'irradiar'; a palavra tem afinidade com Blitz (relâmpago)" ${ }^{\prime 2}$. O $\dot{\alpha} \lambda \eta \theta \tilde{\omega} \varsigma \quad \beta \lambda \varepsilon \dot{\pi} \pi \omega v$ de Teeteto, portanto, diz: verdadeiramente dirigir o olhar com atenção, uma percepção aguda, aguçada, uma visada desveladora que encara o espantoso turbilhão de trevas. É um olhar (blicken) que é fulminante como um raio (Blitz) em direção à escuridão abissal, um rasgo (Riss) de luz em meio às trevas. Podemos evocar o testemunho de

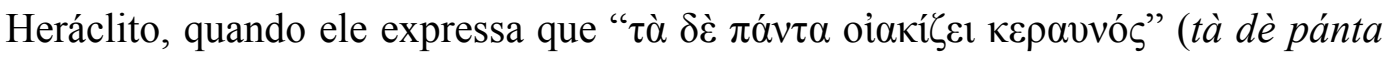
oiakízei keraunós), que pode-se traduzir como "O raio dirige todas as coisas" 30 . Lembremos do ver originário do ser-aí, que opõe-se à sanha da curiosidade, e que não é um ver as coisas manifestas na clareira do mundo, não é visar o ente, mas sim o ver que responde ao chamado do ser e que permite enxergar aquilo que encontrava-se velado, rasgar o tecido do impessoal a fim de desvelar o próprio que a cotidianidade oculta.

A resposta de Sócrates é clara: o maravilhar-se, o espantar-se, é o $\pi \alpha ́ \theta$ o

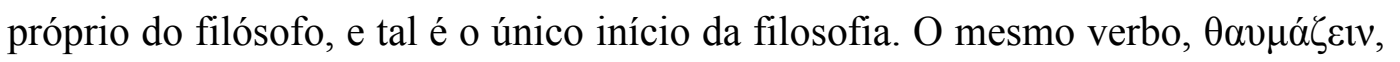
que na fala de Teeteto parece, à primeira vista, ter uma conotação negativa, como algo assombroso, terrível, vertiginoso, na boca de Sócrates soa como algo maravilhoso, admirável. O espanto é, de certo modo, estranheza, e essa ambiguidade de sentidos é vital para ambos. Sua personificação em uma divindade, Taumanto, a quem Sócrates faz referência, é narrada na Teogonia, de

\footnotetext{
${ }^{28}$ Cf. SNELL, A cultura grega e as origens do pensamento europeu, p. 2.

${ }^{29}$ SNELL, Op. cit., p. 3.

${ }^{30}$ HERÁCLITO, Frag. LXIV.
} 
Hesíodo $^{31}$, como sendo filho de Пóvtos (Póntos), o Mar, e Gaia, a Terra. Taumanto é pai de Íris ${ }^{32}$, a personificação do arco-íris, que, por unir o céu e a Terra, é incumbida de ser a mensageira dos deuses, uma ponte entre deuses e mortais. Heidegger chega a dizer que "O homem é como uma ponte constante no entre, como o qual o acontecimento apropriador atribui a indigência dos deuses para a guarda do homem, na medida em que ele assume a responsabilidade pelo homem e o entrega ao ser-aí "33. O homem, enquanto ente dotado de ser-aí, é o entre o divino e o humano, mas não como se ambos, o divino e o humano, fossem coisas dadas, margens definidas ou algo do tipo. O ser-aí é ambos, simultaneamente, sem ser nenhum, especificamente. Ele é o que dá sentido a ambos, é o que há de con-creto, isto é, o que con-cresce, faz crescer junto. O seraí, enquanto o entre, é, pois, a dobra entre o ôntico e o ontológico. Ele transcende o ôntico, mas não no sentido do transcendente separado ( $\chi \omega \rho ı$ нó́ $/$ khorismós), apartado do real, que é o transcendente no sentido platônico/metafísico. Não:

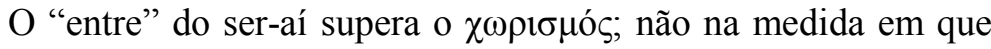
ele constrói uma ponte entre o seer e o ente como margens por assim dizer presentes, mas na medida em que ele transforma o seer e o ente ao mesmo tempo em sua coetanidade ${ }^{34}$.

Também o homem, como essa ponte entre o divino e o mortal, é filho do Espanto, tal como Íris. A filosofia, enquanto o questionar do ser, nasce a partir da disposição do espanto, e surge assim o homem entendido como o entre, a "dobradiça" do real.

Passemos ao testemunho de Aristóteles. No primeiro livro de sua assim

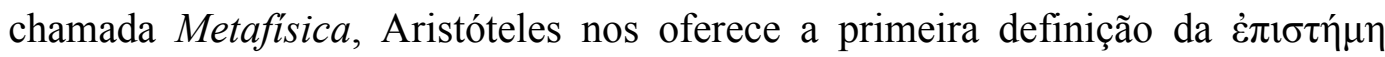
(epistéme), do conhecimento ou "ciência", ali em questão: a бọía (sophía), a

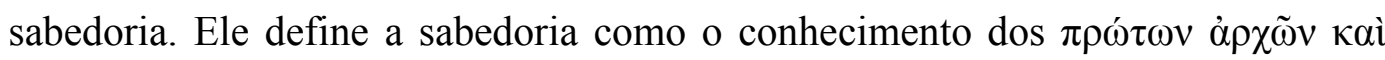

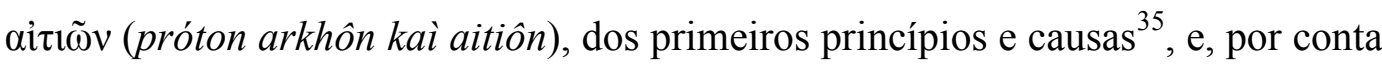
disso, o sábio seria aquele que conhece o fim, isto é, o bem de cada coisa, seja no particular ou no universal - o sumo bem, no caso -, já que o bem, entendido como fim, é uma das causas. O problema que Aristóteles levanta nesse contexto é o de,

\footnotetext{
${ }^{31}$ HESÍODO, Teogonia, v. 237, p. 115.

${ }^{32}$ Cf. HESÍODO, Teogonia, vv. 265-269 e v. 780 ss.

${ }^{33}$ HEIDEGGER, Contribuições à filosofia, §271, p. 472.

${ }^{34}$ Idem, ibidem, §5, p. 18.

${ }^{35}$ ARISTÓTELES, Metafísica, A $982 \mathrm{~b} 9$.
} 
já que tal investigação dos primeiros princípios e causas é, em si mesmo, “inútill", o que faz com que alguns homens levem-na a cabo?

De fato, os homens começaram a filosofar, agora como na origem, por causa da admiração $(\theta \alpha \nu \mu \alpha ́ \zeta \varepsilon v v)$, na medida em que, inicialmente ( $\dot{\rho} \rho \chi \tilde{\eta} \varsigma / a r k h e ́ s)$, ficavam perplexos ( $\dot{\alpha} \tau o ́ \pi \omega v$ $\theta \alpha v \mu \alpha ́ \sigma \alpha v \tau \varepsilon \varsigma / a t o ́ p o n ~ t h a u m a ́ s a n t e s)$ diante das dificuldades mais simples; em seguida, progredindo pouco a pouco, chegaram a enfrentar problemas sempre maiores (...). Ora, quem experimenta uma sensação de dúvida ( $\dot{\alpha} \pi$ o $\tilde{\omega} v /$ aporôn) e

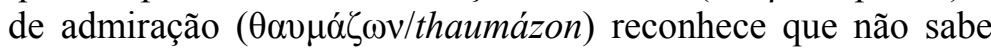
(àjvoeĩv/agnoêin); e é por isso que também aquele que ama o mito ( $\varphi \imath \lambda o ́ \mu v \theta o \varsigma /$ philómythos) é, de certo modo, filósofo: o mito, com efeito, é constituído por um conjunto de coisas

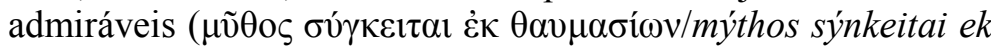

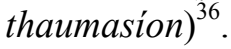

De início, já vemos uma afinidade entre aquilo dito por Platão no Teeteto e a consideração de Aristóteles. Platão já havia sido incisivo ao afirmar não haver outro início do filosofar que não o $\theta \alpha \tilde{u} \mu \alpha$, e isso é ratificado por Aristóteles. Aristóteles, no entanto, parece dar um passo adiante, ao dizer o que gera tal

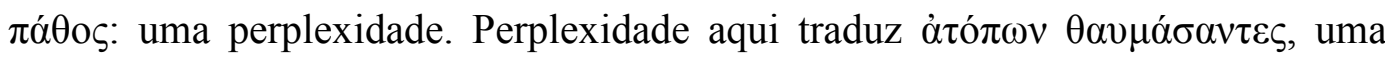

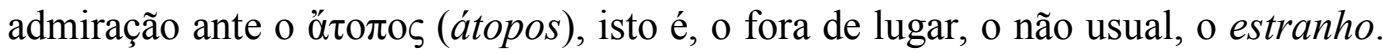
Lida-se corriqueiramente com as coisas do mundo, de modo que possuímos já uma certa compreensão das coisas e de seu lugar no mundo de maneira quase instintiva. Todavia, não poucas vezes encontramo-nos diante de dificuldades que nos tiram o chão, e aquilo que há um segundo atrás acreditávamos estar seguros e confiantes quanto ao que era se mostra de modo incompreensível. É isso a aporia: encontrarmo-nos sem saída. Imersos na égide da interpretação pública do senso comum, tomamos todas as coisas como certas e asseguradas. Quando nos surpreendemos pelo fato de nossa atenção realmente se voltar para as coisas, e, assim, percebemos que não sabemos essencialmente o que a coisa é, tem-se aí o espanto. Aquilo que se presentava como o mais conhecido eu, no fundo, não conheço.

Também aqui em Aristóteles podemos ver o princípio do filosofar como um rompimento do impessoal. A dúvida que leva à aporia faz dissolver tudo aquilo que dávamos como dado e conhecido sem sombra de dúvidas, faz com que finalmente a falação dê lugar ao silêncio, e a curiosidade ao ver. É como se, espantados, nos colocássemos no lugar de Adão, como se experimentássemos o

\footnotetext{
${ }^{36}$ ARISTÓTELES, Metafisica, A 982b11-19.
} 
mundo pela primeira vez. Tal como Adão, somos, então, incubidos da tarefa de nomearmos todas as coisas, e esse esforço de trazer à palavra como que pela primeira vez aquilo que até então era conhecido, familiar, pode ser entendido como o poético em sentido mais elevado. Fernando Pessoa disse certa vez:

Há para mim um significado mais profundo do que as lágrimas humanas no aroma do sândalo, nas velhas latas num monturo, numa caixa de fósforos caídas na sarjeta, em dois papéis sujos que, num dia de ventania, rolarão e se perseguirão rua abaixo. É que a poesia é espanto, admiração, como de um ser tombado dos céus, a tomar plena consciência de sua queda, atônito diante das coisas. Como de alguém que conhecesse a alma das coisas e lutasse para recordar esse conhecimento, lembrando-se de que não era assim que as conhecia, não sob aquelas formas e aquelas condições, mas de nada mais se recordando ${ }^{37}$.

Por conta disso, Aristóteles diz que também o $\varphi \imath \lambda o ́ \mu v \theta o \varsigma$, o amante dos mitos, é de certo modo filósofo. O mito também surge do espanto, também é a tentativa de trazer à tona a fala da linguagem velada pela cotidianidade. $\mathrm{O}$ mito também estabelece o sentido do mundo, sentido que é o próprio mundo. Com efeito, o $\mu \tilde{v} \theta \mathrm{o} \varsigma$ (mýthos) já sempre é $\lambda o ́ \gamma o \zeta$, ao contrário da explicação difundida $\mathrm{e}$ corriqueira segundo a qual, de modo "progressista", "iluminista" ou até mesmo "positivista", antes da filosofia, quer dizer, da "razão", o grego dispunha dos mitos como uma tosca e infantil "explicação" do mundo, ele resguardava-se na invenção fantasiosa para não sucumbir à falta de sentido de tudo que o rodeava. Com o surgimento da filosofia, o homem se apercebe de que aquilo não passa de ficção e passa a buscar a verdade das coisas. Logo, o $\mu \tilde{v} \theta o \varsigma$, entendido como

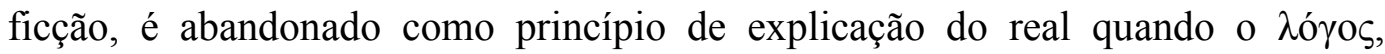
entendido como ratio, razão, se impõe e estabelece a medida e o critério da verdade, e, sob essa perspectiva, o mito passa a ser mentira, falsidade, fantasia.

Platão e Aristóteles nos dão testemunhos semelhantes. Ambos evocam o espanto como princípio do filosofar, e ambos entendem esse espanto como um rompimento da compreensão mediana e pública do impessoal. Nesse sentido,

\footnotetext{
${ }^{37}$ PESSOA, "O eu profundo". In: Alguma prosa, p. 20. Heidegger mesmo chega a dizer que "Pensar aqui significa deixar os entes emergirem na decisividade de seu ser e deixá-los que se manifestem diante de nós, de modo a, percebendo-os enquanto tais, nomeá-los em sua entidade pela primeira vez". [Tradução livre de: "For thinking means here to let beings emerge in the decisiveness of their Being and to let them stand out before oneself, to perceive them as such and thereby to name them in their beingness for the first time"] (HEIDEGGER, Basic questions of philosophy, p. 133) Nesse sentido essencial, portanto, pensar é nomear. Heidegger também diz, em outra oportunidade: "O pensador diz o ser, o poeta nomeia o sagrado. (HEIDEGGER, Posfácio a "O que é metafisica?", p. 324).
} 
Heidegger chegou a afirmar: "Somente quando a estranheza do ente nos acossa, ela desperta e atrai para si a admiração. É somente baseado na admiração - quer dizer, na manifestabilidade do nada - que surge o "por quê?"38. A estranheza do ente, die Befremdlichkeit des Seienden, é a estranheza do sentido do se mostrar estranho como o não usual, o não comum. É o caráter de estrangeiro do ente, que, manifesto, nos espanta. Somos estranhos (umheimlich) porque o mundo, nosso próprio lar, tudo que consideramos familiar, no fundo nos é algo de estrangeiro (befremdlich), desconhecido. Apercebermo-nos disso nos causa admiração (Verwunderung). O ponto que Heidegger quer ressaltar, no entanto, é de que essa admiração, que é a origem de todo filosofar, não é nada psicológico, mas sim um acontecimento apropriador do próprio ser. Essa aflição angustiante (Not, que em alemão também diz necessidade) é

um caráter do ser e não do homem, como se essa aflição pudesse surgir "psiquicamente" no homem como uma "vivência", tendo nele seu lugar próprio. Ao contrário, o homem mesmo surge primeiramente dessa aflição, que é mais essencial que ele mesmo, pois ele é determinado por ela. (...) Esta aflição pertence à própria verdade do ser. Ela é possuidora da maior dádiva, na medida em que é o solo da necessidade em direção às possibilidades mais elevadas, no caminho no qual o homem, em suas criações, supera a si mesmo e retorna através dos entes para a verdade do $\operatorname{ser}^{39}$.

Se partirmos de uma concepção ôntica do homem, seja de modo biológico ou psicológico, fatalmente iremos ver de modo inessencial o fenômeno da admiração advinda da aflição de sermos jogados no mundo. A admiração, ou o espanto (Erstaunen) ${ }^{40}$, é uma disposição de ânimo, e, portanto, como já visto, trata-se de algo de caráter ontológico-existencial. Qualquer interpretação psicológica desse fenônemo mostrar-se-á insuficiente. Heidegger quer com isso fazer com que pensemos o espanto muito além da mera surpresa que porventura ocorre na lida com os entes dispostos como manualidade. $\mathrm{O}$ espanto não tem nada de óbvio ou ordinário. Ele é justamente a visão do não-usual no usual, em meio ao

\footnotetext{
${ }^{38}$ HEIDEGGER, O que é metafisica? In: Marcas do caminho, p. 132.

${ }^{39}$ HEIDEGGER, Basic questions of philosophy, p. 133. Tradução livre de: "a character of Being and not of man, as if this distress could arise "psychically" in man as a "lived experience" and have its proper place in him. On the contrary, man himself first arises out of this distress, which is more essential than he himself, for he is first determined by it. (...)This distress pertains to the truth of Being itself. It possesses its highest gift in being the ground of the necessity toward the highest possibilities, on the path of which man in his creations surpasses himself and returns through beings to the truth of Being".

${ }^{40}$ Heidegger associa ambos os termos, Erstaunen e Wervunderung, como significando o mesmo. Cf. HEIDEGGER, GA 45, p. 162.
} 
usual. Por conta disso, "a admiração é uma certa incapacidade de explicar e uma ignorância da razão"41. Essa incapacidade que temos de oferecer uma explicação não significa que somos incompetentes, ou que nossa razão não é desenvolvida o suficiente. Trata-se, ao contrário, justamente de ser acometido, de modo violento, pelo inexplicável. É a fascinação pelo inexplicável enquanto tal, ao incomum, em oposição àquilo que já era de há muito conhecido, comum, banal, tedioso.

A admiração, por conseguinte, diferencia-se do maravilhamento, do maravilhar-se (Sichwundern) e do surpreendente (Bewunderung). O que nos maravilha e surpreende ainda está enredado no afã da curiosidade divulgado pela falação. Maravilhamo-nos com as paisagens vislumbradas na viagem que fizemos, registradas em dezenas de fotos, somos surpreendidos pela qualidade de um filme ou livro do qual não tínhamos muita expectativa etc. Nenhum desses fenômenos, no entanto, deixam ser o estranho, o não-usual enquanto tal. O que se oferece à curiosidade é, de certo modo, uma justaposição do inesperado sobre o esperado, mas que ainda é capturado em meio a interpretação mediana pública do impessoal. Há algo de "excitante" nas novidades que alimentam nossa curiosidade, mas isso rapidamente decai no tédio do já visto, já conhecido, é "mais do mesmo". É por isso que somos impelidos a buscar outra novidade, tal como expressa o próprio termo curiosidade em alemão, Neugier. Distintamente, quando somos dispostos pelo espanto,

O comum e o mais comum (...) tornam-se aquilo que é o mais incomum. (...) $\mathrm{O}$ mais comum, que se manifesta no espanto como o incomum, não é isso ou aquilo, algo particular que se mostra como objetivo e determinado em alguma atividade específica ou consideração individual. No espanto, o que é mais comum de tudo e em tudo, isto é, todas as coisas, tornam-se o mais incomum. (...) Todas as coisas, aquilo de mais comum (entes) torna-se, no espanto, o mais incomum neste sentido: elas são aquilo que são (daß es ist, was es ist $)^{42}$.

Os entes, aquilo de mais comum, mostram-se, quando o espanto dispõe o ser-aí, como o mais incomum. O mais incomum do ente é que ele é. Não que o

\footnotetext{
${ }^{41}$ Idem, ibidem, p. 137. Tradução livre de: "Amazement is a certain inability to explain and ignorance of the reason".

${ }^{42}$ Idem, ibidem, p. 144. Tradução livre de: "The usual and the most usual (...) become what is most unusual. (...) The most usual, which arises in wonder as the unusual, is not this or that, something particular that has shown itself as objective and determinate in some specific activity or individual consideration. In wonder, what is most usual of all and in all, i. e., everything, becomes the most unusual. (...) Everything in what is most usual (beings) becomes in wonder the most unusual in this one respect: that it is what it is".
} 
ente seja de tal ou tal modo, simplesmente que ele é. O espanto desvela o ser, o essencialmente velado, em meio ao ente. $\mathrm{O}$ espanto, pois, habita nesse entre: entre o mais comum, ente, e o mais incomum, ser.

O espanto é a viagem de volta do caráter corrente do comportamento no familiar para a abertura do acometimento do que se encobre, em cuja abertura o que há até aqui de corrente se revela ao mesmo tempo como o estranho e como o agrilhoante. $\mathrm{O}$ que há de mais corrente, porém, e, por isto, mais desconhecido, é o abandono do ser. O espantar-se deixa que o homem volte ao fato de que o ente é, enquanto anteriormente o ente para ele era justamente o ente ${ }^{43}$.

O ente na totalidade, isto é, o ente enquanto ente, ens qua ens, tò ôv ị̃ őv, é velado, oculto pelo impessoal, e, assim, o acontecimento fundamental cai no esquecimento. Todavia, o esquecido é rememorado graças ao espanto: os entes são. O espanto é o testemunho de um evento, do acontecimento da verdade do ser em seu sentido mais originário, e é nessa abertura que ele propicia ao ser-aí que ele pode se tornar o sítio do qual emergem homem, filosofia e história, em copertencimento $^{44}$. O espanto é o princípio do filosofar, entendido como o pôr-se dis-posto na abertura da verdade do ser de modo a pensar e, assim, questionar o ente em sua totalidade, questionar esse que funda o homem histórico na medida em que somente nessa disposição ele se apercebe de seu caráter histórico sob a óptica da história do ser. O espanto é, pois, uma disposição fundamental, como a angústia. Essencialmente compreendido, espanto e angústia dizem o mesmo. O que é o mais incomum que se revela no mais comum? Nada, pois aquilo que é comum é o ente. O nada é o próprio ser. O nada tem a amplitude daquilo que garante, a todo ente, ser. No entanto, o ser não é uma propriedade do ente, o ente não "tem" ser. O fato é que o ser nunca se essencia sem o ente, ao mesmo tempo em que o ente jamais é sem o ser. A verdade do ser é a doação de si que se vela. Dá-se ser (Es gibt Sein). O "se" do "dá-se" que é o grande mistério. O ser é o puro outro em relação ao ente, é a radical diferença. O filosofar se dá, por conseguinte, quando somos capazes de perceber o diferente no mesmo, sustentarmos a pura diferença enquanto tal.

\footnotetext{
${ }^{43}$ HEIDEGGER, Contribuições à filosofia, §5, p. 19.

44 “Na medida em que o homem se joga para fora do 'ente', ele se torna pela primeira vez homem. Pois somente assim ele retorna ao ente e é como o que retornou”. HEIDEGGER, Contribuições à filosofia, §263 p. 436.
} 
Se, em meio ao ente, ou seja, insistindo em nosso "aí", estamos imersos na barulheira da falação, o diferente se mostra como silêncio. Quando o silêncio fala, eis a voz do ser chamando o ser-aí. A angústia é a disposição de ânimo instaurada pela voz do silêncio. Se, angustiados, nos compreendemos como estranhos, nos apercebemos que não somos nada, isso quer dizer que a angústia nos possibilita a experiência de ser como o outro em relação a todo ente. Ela nos põe diante do abismo do nada. É por isso que nos espantamos. Nesse sentido, Heidegger assevera:

A prontidão para a angústia é o sim à insistência para realizar a mais elevada requisição, a única a atingir a essência do homem. Somente o homem, em meio a todos os entes, experimenta, chamado pela voz do ser, a maravilha de todas as maravilhas: o fato de que o ente $\mathrm{e}^{45}$.

Por que é que, afinados pela angústia, ficamos estranhos? Por que a estranheza nos é tão essencial? Porque, essencialmente, somos ser-aí. O ser mesmo é aquilo que de mais estranho há. O ser é o que há de mais inabitual em toda a incontornável habitualidade do ente. Todavia, o fato de o ser só poder se essenciar como ente diz que o que há de mais estranho também precisa disso que há de mais banal, familiar, corrente, rotineiro. Por isso que não é nenhum acidente que o ser-aí seja insistente, isto é, que já sempre insista em ser seu “aí”. Encarar, em meio às coisas, a possibilidade do nada: isso significa ser-para-a-morte. A morte é a testemunha da estranheza do ser. Angustiados, morremos para o impessoal; insistentes, morremos para nós próprios. É nesse sentido que apenas o homem morre, pois a morte aqui não é o oposto da vida.

Ao fato de sempre fugirmos de nós próprios e insistirmos na cotidianidade, Heidegger deu o nome de errância. Errar é desviar-se do mistério. Errância é, pois, o fato de afundarmos no esquecimento do ser. Nesse sentido, toda a história da metafísica é a história da errância do homem. Dar valor ao ente e pensar o ser a partir dele é esquecer-se do ser de modo radical. Como o ser sempre se oculta, isto é, ele nunca é nada de óbvio, familiar e habitual, o esquecimento do ser é inevitável. O fato da fuga de si mesmo do ser-aí ser estrutural o atesta. Insistir na facticidade do "aí" é esquecer o ser. O ponto é sermos capazes de pensar que, justamente, o ser é esquecimento. O esquecimento

\footnotetext{
${ }^{45}$ HEIDEGGER, Posfácio a "O que é metafisica?". In:
} Marcas do caminho, p. 319. 
do ser é estrutural. O abandono do ser se dá quando nos esquecemos do esquecimento.

O abandono do ser é o mais forte possível lá onde ele se esconde da maneira mais decidida. Isso acontece lá onde o ente se tornou e precisou se tornar o mais habitual e o mais habitado. Isso aconteceu em primeiro lugar no Cristianismo e em sua dogmática, segundo os quais todo ente é explicado em sua origem como ens creatum e onde o criador é o que há de mais certo, assim como todo ente se revela como o efeito dessa causa de todas a mais essente. A relação de causa e efeito, porém, é o que há de mais comum e mais tosco e próximo, aquilo de que busca auxílio todo cálculo e toda perdição humana em meio ao ente, a fim de explicar algo, ou seja, de voltar algo para o interior da clareza do que é comum e habitual. Aqui, onde o ente precisa ser o que há de mais habitual, o seer é necessariamente aquilo que se mostra tanto mais plenamente como habitual e como o que há de mais habitual. E como então, em verdade, o seer "é" o que há de mais inabitual, o seer se subtraiu aqui completamente e abandonou o ente ${ }^{46}$.

Se a história da metafísica é a história da errância, enquanto esquecimento do ser, nossa época atual, que é a da culminação da metafísica, é a época do mais radical esquecimento do ser, do mais vigoroso abandono do ser. Culminação da metafísica: isso já havia sido aludido anteriormente. A metafísica de Nietzsche, segundo Heidegger, marca o fim da metafísica. Essa compreensão só é possível a partir do ponto de vista da história da verdade do ser. Com essa expressão, Heidegger não busca uma apropriação de uma filosofia da história de cunho hegeliano ou marxista, ou seja, uma história entendida dialeticamente, regida por leis internas. Tampouco se trata de uma história - no sentido de historiografia - da filosofia, de elencar as sucessivas contribuições dos pensadores, um encadeamento progressivo de diversas "visões de mundo". Tratase da história do acontecimento apropriador da verdade do ser, isto é, dos diferentes modos em que o ser foi apropriado, e de como que isso definiu o destino do ocidente. Destino (Schicksal) é um envio (schicken). Destino, entendido como história do ser, é pois Geschick, no sentido de uma reunião (Ge-) de envios. Os envios do ser, que, doando-se, clama silenciosamente pela apropriação, constituem o destino. Destino, portanto, não é fatalidade, um fim providencial definido. Destino é o modo como nossa história, que nos determina em nossa existência fática, nos desafia e impele a nos apropriarmos do ser, isto é,

\footnotetext{
${ }^{46}$ HEIDEGGER, Contribuições à filosofia, §52, p. 109.
} 
o modo como somos historicamente compelidos a nos apropriarmos do ser, que, em última instância, diz o modo como compreendemos ser. Somos compreensão de ser, e essa compreensão é determinada historicamente.

História do ser significa destino do ser - e nessas destinações tanto o destinar como o Se [no sentido do "dá-se" ser] que destina se retém com a manifestação de si mesmos. Reter-se significa em grego epoché. Por isso se fala de época do destino do ser. Época não significa aqui um lapso de tempo no acontecer, mas o traço fundamental do destinar, a constante retenção de si mesmo em favor da possibilidade de perceber o dom, isto é, o ser em vista da fundamentação do ente. A sucessão das épocas no destino de ser não é nem casual nem se deixa calcular como necessária. Não obstante, anuncia-se no destino aquilo que responde ao destino e no comum-pertencer das épocas aquilo que convém. Estas épocas se encobrem, em sua sucessão, tão bem que a destinação inicial de ser como presença é cada vez mais encoberta de diversas maneiras ${ }^{47}$.

A filosofia tem início com o primeiro acontecimento apropriador do ser, a primeira resposta ao seu chamado silencioso. Desde então, houve uma série de repetições desse acontecimento. As repetições são repetições da diferença. $O$ mesmo que, em si mesmo, se diferencia. O ser é esse mesmo, e o ser é essa diferença. Deixar-se apropriar pelo ser é o acontecimento que define uma época. Época que, como supracitado, é a retenção do ser que propicia seu esquecimento. O modo como cada época se esquece do ser significa o modo como cada época compreende o ente, ou o modo como cada época é desafiada historicamente a compreender o ente.

Podemos verificar historiograficamente a profusão de transformações mostrando que o presentar se manifesta nos primórdios como o Hén, o unificante único-uno, como o Lógos, o recolhimento que guarda o todo, como a idéa, ousía, enérgeia, substantia, actualitas, perceptio, mônada, como objetividade, como formalidade do impor-se no sentido da vontade, da razão, do amor, do espírito, do poder, como vontade de vontade, no eterno retorno do mesmo ${ }^{48}$.

Heidegger foi o pensador que compreendeu a necessidade da superação da metafísica. Ser e tempo, mais do que uma obra, foi o engatinhar, os primeiros passos dessa tarefa. Os passos seguintes exigiriam uma virada, uma transformação do pensamento. Pensar a essência da verdade como a verdade da essência, o ser da verdade como a verdade do ser. Isso vai de encontro com a concepção metafísica

\footnotetext{
${ }^{47}$ HEIDEGGER, Tempo e ser. In:

${ }^{48}$ Idem, ibidem, pp. 458-459. Conferências e escritos filosóficos, p. 459.
} 
que define nossa época, ao mesmo tempo em que a evidencia. Pela citação acima, Heidegger deixa claro que a última instância "historiográfica" da metafísica é o pensamento de Nietzsche. Do modo como Heidegger vislumbra a história do ser, a metafísica acaba em Nietzsche. O pensamento nietzscheano é sua consumação. Não à toa, portanto, o pensamento de Heidegger após a virada confronta, agonicamente, o pensamento nietzscheano. Um tal embate era inevitável.

A superação da metafísica deve necessariamente passar por um enfrentamento do pensamento nietzscheano. Entretanto, que significa superação da metafísica? Trata-se de deixar a metafísica de lado com desdém, pois trata-se de um erro e, portanto, é inútil, perda de tempo levá-la em consideração? Sob nenhuma hipótese. Tampouco trata-se de eliminar uma disciplina acadêmica ou uma área do saber. Superar quer dizer: ultrapassar. A história do ser não é a história de um progresso, como se os pensadores fossem superando uns aos outros, gerando obsolescência. É a ciência, particularmente o positivismo, que compreende assim a história. Toma-se dois pontos, A e B, traça-se uma linha entre eles e valora-se tal linha. A este valor chamam progresso. Não é raro, pois, encontrar histórias da filosofia que afirmam que Aristóteles superou Platão, ou que Kant superou Descartes e Hume, por exemplo. Para a filosofia, essencialmente entendida, não há progresso. Há respostas para os chamados do ser, de modo a dizer o mesmo diferentemente. "Mesmo" aqui quer dizer o ser. $\mathrm{Na}$ história da metafísica, o ser do ente.

Nietzsche, segundo Heidegger, pensa o ser do ente como vontade de poder. Tudo que é, sendo, é vontade de poder. Por pensar o ser a partir do ente, Nietzsche é também um metafísico. Vontade de poder é o caráter fundamental de todo ente na medida em que é, é a essência do ente enquanto ente. E de que modo, para Heidegger, dá-se a vontade de poder? Como o eterno retorno do mesmo ${ }^{49}$. E isso porque, de acordo com Heidegger, Nietzsche entende a essência da própria vontade como vontade de poder, ao passo que a essência do poder nada mais é que a vontade ${ }^{50}$. Poder é o querer no sentido de uma autoafirmação, de assenhorear-se sobre algo. Querer é querer mais. Vontade de poder, por conseguinte, é vontade de vontade. Isso significa: o querer que quer a si próprio,

\footnotetext{
${ }^{49}$ Cf. HEIDEGGER, Nietzsche, p. 14.

${ }^{50}$ Idem, ibidem, p. 28.
} 
querer o querer, o querer que volta-se sobre si e se quer. É o eterno retorno do querer por sobre si mesmo. O ser tomado como vontade de querer interrompe o destino, entendido como envio do ser. A história do ser, entendida como história da própria metafísica, chega ao fim. Inicia-se agora uma nova época: a era da metafísica acabada.

Com a metafísica de Nietzsche, a filosofia acaba. Isso quer dizer: ela já percorreu todo o âmbito das possibilidades que lhe foram presignadas. $\mathrm{O}$ acabamento da metafísica, que constitui o fundamento do modo planetário de pensar, fornece a armação para uma ordem da terra, provavelmente bastante duradoura. Esta ordem já não mais precisa da filosofia porque de há muito a ela já sucumbiu. Com o fim da filosofia, porém, o pensamento não está no fim, mas na ultrapassagem para um outro começo ${ }^{51}$.

Com Nietzsche, a metafísica está sem seu acabamento. Todavia, "O acabamento dura mais do que a história da metafísica transcorrida até aqui" ${ }^{3}$. Que significa esse durar? Mera contagem do tempo? Logo, se a metafísica até aqui conta com uma história de 2500 anos, a sua superação deve durar uns 3000 anos? Claramente não é isso. A duração do acabamento diz que a metafísica é passado, mas não esse passado datável, quantificável; dizer que a metafísica é passado é dizer que ela re-passa e passa para o vigor de ter sido ${ }^{53}$. O acabamento da metafísica dura mais porque é agora que a metafísica vigora com mais intensidade. Vivemos o fim da filosofia, que é também o início de seu acabamento. Hodiernamente, vivemos essa época. De que modo, então, somos historicamente desafiados pelo ser em nossa compreensão e lida mais imediata com os entes? "Pode-se chamar, numa única palavra, de 'técnica' a forma fundamental de manifestação em que a vontade de querer se institucionaliza e calcula no mundo não-histórico da metafísica acabada" ${ }^{\text {. }}$.

"Técnica", aqui, diz muito mais do que um saber técnico específico, um know-how, e é algo muito mais profundo e essencial que quaisquer maquinários ou invenções tecnológicas. A técnica também não deve ser compreendida de modo antropológico-instrumental, isto é, como um meio para um fim instrumental, no sentido de ser um meio, e antropológica, no sentido de servir a um fim designado pelo homem. Ao contrário, é a técnica que, antes, utiliza-se do

\footnotetext{
${ }^{51}$ HEIDEGGER, A superação da metafisica. In:

${ }^{52}$ Idem, ibidem, p. 61. Ensaios e conferências, p. 72.

${ }^{53}$ Idem, ibidem.

${ }^{54}$ Idem, ibidem, p. 69.
} 
homem. Entendida de modo essencial, "a técnica é uma forma de desencobrimento" ${ }^{, 55}$. Isso significa que a técnica é um modo da verdade, isto é, o modo como a verdade do ser se manifesta em nossa época. À essência da técnica, Heidegger dá o nome de Gestell, termo que admite muitas traduções possíveis, como composição, armação, enquadramento, entre outras. $O$ termo é uma reunião (Ge-) de posicionalidades (stellen). A técnica, enquanto Gestell, com-posição, põe e dis-põe o homem de modo desafiador a se im-por à natureza, para dela tornar-se senhor e mestre. A técnica, cuja essência é a composição, é a reunião dessas posicionalidades em relação ao homem. Essa reunião de sentido em uma unidade

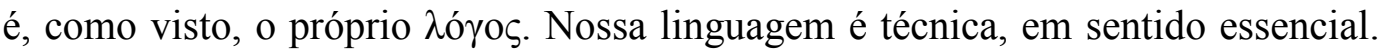
A técnica é nosso horizonte de sentido, e, nesse sentido, nosso mundo.

O uso do termo "posicionalidade" aqui não é casual. Como Heidegger observou, é esse o sentido essencial da compreensão de ser da modernidade. O ente é a pura posição posta pelo sujeito, que, enquanto tal, é o fundamento do real. Isso fica claro com Kant e o desdobramento do cogito cartesiano para o Eu-penso entendido como a unidade sintética da apercepção transcendental. Kant chega mesmo a explicitar a sua concepção de ser:

Ser não é, evidentemente, um predicado real, isto é, um conceito de algo que possa acrescentar-se ao conceito de uma coisa; é apenas a posição de uma coisa ou de certas determinações em si mesmas. No uso lógico é simplesmente a cópula de um juízo ${ }^{56}$.

O sujeito kantiano, sendo transcendental, não só é o fundamento da realidade efetiva (Wirklichkeit, que vem de wirken: produzir, efetivar) como também é a condição de possibilidade dessa realidade. $O$ real que se deixa experimentar e conhecer é efetivado pelo sujeito, isto é, é posto e imposto pela subjetividade. a realidade efetiva é pro-duzida pelo sujeito transcendental, se se entende produzir em seu sentido primordial de pro-ducere, pro-duco: trazer e pôr diante de, em alemão: vor-stellen, re-presentar. Tal "pôr diante de" diz também contra-pôr, Gegen-stand, ob-jectum. Objeto, obiectum, vem de obiciō: diante de, o-posto; objeto, portanto, significa: presença à vista. $\mathrm{O}$ objeto é o efetivamente real o absolutamente posicionado. O fenômeno, portanto, é sempre objeto e, sendo objeto, é sempre também representação. O mundo é sempre uma re-presentação

\footnotetext{
${ }^{55}$ HEIDEGGER, A questão da técnica. In:

${ }^{56}$ KANT, Crítica da razão pura, A598/B626. Ensaios e conferências, p. 17.
} 
do sujeito. A realidade se presenta à sensibilidade do sujeito, e este a re-presenta como objeto do conhecimento. É nesse sentido que Heidegger diz que, na modernidade, o mundo se transformou em imagem. Sendo imagem, o mundo é mera externalização do entendimento humano, é o entendimento humano objetificado e objetivável. Isso permite a absoluta matematização do mundo, sistematização, racionalização do real. O real passa a ser o contável, o calculável.

A técnica, enquanto forma da verdade, nos desafia a compreender o ser já sempre de certo modo. Vimos que, enquanto entes dotados de ser-aí, somos essencialmente compreensão de ser, e que essa compreensão que precede e condiciona toda e qualquer lida com as coisas é determinada historicamente. Nossa época histórica nos determina a compreendermos os entes, de imediato, como Bestand, isto é, insumo, estoque de reservas. Em nossa hodierna lida cotidiana para com as coisas, já sempre as compreendemos como um "bem de capital", como algo disponível para ser explorado, como algo passível de ser estocado. Tudo com o que lidamos tem o seu valor calculado a partir desse critério. Com efeito, o cálculo impõe-se como sendo o pensamento propriamente dito; pensar é calcular e vice-versa. O domínio do cálculo é "causa" e "efeito" do abandono do ser. O cálculo,

estabelecido pela primeira vez no poder por meio da maquinação da técnica, maquinação essa que se funda, em consonância com o saber, na matematização; aqui a conceptualidade prévia se mostra obscura em termos de sentenças diretrizes e de regras, e, por isso, a segurança da direção e do planejamento, o ensaio; a inquestionabilidade do atravessar de algum modo; nada é impossível, se está certo do "ente"; (...) o incalculável é aqui apenas o ainda não dominado pelo cálculo, mas que em si pode ser expressamente capturado (...). O cálculo é visado aqui como a lei fundamental do comportamento, não como a mera reflexão e até mesmo a astúcia, que pertencem a todo modo de agir humano ${ }^{57}$.

O cálculo, como lei fundamental do comportamento, diz aquilo que é condicionante em toda interpretação, e, portanto, na pré-compreensão, que fazemos das coisas. Agimos, em todas as esferas da vida, de modo calculante. Cálculo, como visto no primeiro capítulo, é um contar-com. São dois termos que evocam a matemática. De fato, a matematização do mundo, tornada possível pela transformação do mundo em mera imagem, isto é, em uma representação do

\footnotetext{
${ }^{57}$ HEIDEGGER, Contribuições a filosofia, §58, p. 119.
} 
sujeito humano e para o sujeito humano, entendido como coisa pensante, res cogitans, explica não só o domínio absoluto das ciências ditas exatas, como também a nossa tara por pesquisas e estatísticas. Calcular e contar-com é o modo como expressamos a vontade de querer como essência do ente, isto é, vontade de dominação da Terra, de controle e asseguramento de todos os âmbitos da existência.

O cálculo planejador torna o ente cada vez mais re-presentado, cada vez mais acessível em todo e qualquer aspecto possível da explicação; e isso de tal modo, em verdade, que essas controlabilidades se unificam entre si e se tornam mais correntes e, assim, o ente é ampliado em direção ao aparentemente ilimitado; todavia, justamente apenas aparentemente. (...) E num instante, uma vez que o planejamento e o cálculo se tornaram gigantescos, o ente na totalidade começa a encolher. O "mundo" se torna cada vez menor; e não, por exemplo, apenas no sentido quantitativo, mas no significado metafísico, o ente enquanto ente, isto é, como algo objetivo, é, por fim, a tal ponto dissolvido na controlabilidade, que o caráter de ser do ente por assim dizer desaparece e o abandono do ser do ente se consuma. O apequenamento metafísico do "mundo" gera um esvaziamento do homem ${ }^{58}$.

A era da técnica é a era do maior dos perigos, de um perigo tão avassalador que não há precedentes dele na história. Imediatamente pensamos que esse perigo se trata da bomba atômica, que revela todo o potencial destrutivo da tecnologia. Não faltarão, no entanto, listas dos benefícios trazidos pela tecnologia, como contraposição, numa crença pressuposta de que a tecnologia é neutra e o homem, seu mestre, seu criador e dono, a pode usar para o bem ou para o mal, dependendo da sua pré-disposição ou de seu caráter. A essência da técnica, Gestell, é o modo de desvelamento do ser que impera em nossa época. Imperando, ela nos desafia a compreender o ente em sua totalidade já sempre como insumo, estoque e disponibilidade para uso. Ela não é "neutra" porque um juízo de valor desse tipo já compreende a técnica inessencialmente. Listar os benefícios e os malefícios da técnica já é sempre compreendê-la tecnicamente, e não ontologicamente, isto é, já é lidar com ela metafisicamente, o que aqui significa como um objeto do e para nosso conhecimento. Tanto a bomba atômica quanto o aparelho hospitalar de ressonância magnética são frutos do abandono do ser.

\footnotetext{
${ }^{58}$ Idem, ibidem, $\$ 274$ pp. 478-479.
} 
Esquecer-se do esquecimento do ser é o maior dos perigos. Os "perigos" ônticos são sempre tardios, consequências desse maior perigo.

E por que o abandono do ser é o maior dos perigos? Porque ele permite o domínio absoluto e, portanto, indisputado do impessoal. O desafiar da Gestell de nos assenhorarmos da natureza como seus senhores e mestres não encontra oposição, desafiantes dignos de porem-se em seu caminho. A falação vira a norma absoluta da linguagem, a curiosidade reina tiranicamente, e a ambiguidade, com isso, potencializa-se assustadoramente, pois deixa marcado a ferro na impropriedade a imagem aparente e ilusória da propriedade. $\mathrm{O}$ desafio da técnica passa a ser imposição. Somente a sua representação vale. Possuindo validade absoluta, ela dispõe de mais força, mais vigência, mais dominação. Não é que ela seja mais forte, mas precisa lidar com as objeções de representações mais fracas que a contestem: ela é a única. Ela esmaga todas as outras possibilidades, apropria-se delas, incorpora-as a si. "Ora, então a técnica é má", podemos concluir, "é algo diabólico, que divide a humanidade, a dispersa, a controla, a domina”. Não. Ela não é nem boa, nem neutra, nem má. A técnica é. Ela, como verdade do ser, dá-se. Nessa doação, ela determina nossa época, e essa determinação histórica nos determina em nossa essencial compreensão de ser. Gratuitamente, sem por quê nem para quê.

O perigo, portanto, é o abandono do ser não ser levado em conta, é o ser ser radicalmente esquecido em sua "esquecidade" essencial. Desse modo, se o ser é abandonado, seu chamado não nos compele. Se todos os eventos históricomundiais fazem questão de serem alardeados de modo barulhento, não somos capazes de ouvir o silêncio de sua fala. Se o nosso afã de ver tudo, saber tudo e se informar de tudo reina de modo inquestionado, ficamos cegos pela sua claridade. Se a ambiguidade faz com que a informação seja considerada conhecimento, que a erudição seja considerada sabedoria etc., então nunca seremos capazes de nos ater a nada de modo a verdadeiramente questionar. Não pensamos. Pensar, essencialmente, é pensamento do sentido, do sentido de ser, da verdade do ser. Heidegger chama esse pensar essencial de "meditação" (Besinnen). O prefixo be-, em alemão, acarreta uma mudança de estado, uma intensificação, no sentido de tocar, aprofundar; sinnen quer dizer pensar, ponderar, cogitar, mas traz em si Sinn, sentido, sentir. Besinnen diz, pois: mudança de sentido. Meditar é, assim, um 
pensar extraordinário, um pensar que escapa de nossas representações, conceitos e pressuposições cotidianas. Essa inversão pode ser compreendida como uma verdadeira $\mu \varepsilon \tau$ óvoia (metánoia), uma conversão, uma mudança de pensamento.

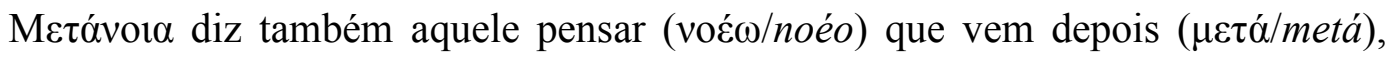
que curiosamente corresponde ao termo alemão nachdenken, comumente traduzido por meditar. Em certo sentido, pois, Besinnen é nachdenken, e isso porque a meditação, embora seja o pensar originário, não é o pensar primeiro em nosso sentido temporal comum, porque sempre partimos do cotidiano e de seu "pensar" ordinário. Por conseguinte, o maior dos perigos é nunca sermos capazes de pensar, ficarmos absolutamente incapacitados para o pensamento do sentido. Superação da metafísica agora significa: pensamento do sentido.

Filosofar é realizar esse pensamento do sentido. Esse pensamento, sendo a própria filosofia, tem como sua origem uma disposição de ânimo: o espanto. Como vimos, o espantar-se é uma sustentação daquilo que é inexplicável. Que é inexplicável? Que o mais comum seja o mais incomum. O mais comum, o ente, revela-se de modo admirável: ele não é isso ou aquilo que dávamos como dado, certo e entendido; ele é. O mais incomum no mais comum é o ser. Ora, mas o ser é nada. É nada, pois não é ente algum. Ele é a diferença absoluta para com o ente. Mas só conseguimos oferecer explicações ao ente. Se o ser é nada, então ele não "existe", se compreendermos "existência" como presença à vista, efetividade, objeto do conhecimento. De fato, o ser não "existe", nesse sentido acima. Se ele não existe, se não pode ser conhecido e explicado, ele é inútil, não tem valor. Tudo que é inexplicado, na era da técnica, deve possuir o caráter do "ainda não". Se não foi explicado ainda, se ainda não conseguimos oferecer uma explicação satisfatória, se ainda não nos assenhoramos de sua essência, isto é mera questão de tempo. Se a explicação não puder ser dada em um futuro próximo ou distante, se a ausência de explicação não se der por conta de uma carência de dispositivos, de máquinas, de ampliações potenciais do método experimental, então não é nada que valha a pena ser explicado para início de conversa. Nem se deve perder tempo com isso, já que será sempre e persistirá inexplicado. É inútil, é fútil.

O perigo é a negação absoluta e constante do mistério. Não temos ouvidos e olhos para o mistério. Sequer aceitamos a possibilidade do mistério. Falar em mistério é misticismo, fantasia, superstição, e portanto não é nada de 
científico. Só se pode abrir para o mistério do ser quem experimenta a estranheza. Somos capazes de estranhar o domínio da técnica, de nos apercebemos estranhos e estrangeiros nessa familiaridade imposta com tanta força e veemência? Será que, tomados pela angústia criadora, não nos "angustiaremos" com ela e declinaremos, covardemente, o seu chamado? Não nos decidiremos sempre por persistirmos na fuga de nós próprios? Somos capazes de, humildemente, nos postarmos dispostos diante do mistério? Temos ainda a possibilidade do pudor diante do sagrado?

Nenhuma outra era aqui nossa questão diretriz: somos capazes de sustentar um pensamento sobre o sentido da técnica, o sentido de ser? Somos capazes de estranhar esse domínio de modo a originar um tal pensamento? Heidegger não nos oferece nenhuma resposta pronta a nossa questão, pois não há uma tal resposta. Tampouco temos aqui a pretensão de responder a isto, se entendermos resposta como uma série de proposições que dão conta da amplitude da questão. Heidegger não nos oferece nenhuma resposta técnica. Para o leitor que é incapaz de adentrar em seu pensamento, que só é capaz de analisá-lo externamente, que só consegue sobrevoá-lo, mas nunca se infiltrar, isso pode parecer charlatanismo. Essas opiniões não importam em nada. Importa o fato de um pensamento como o heideggeriano causar tanto incômodo. Mesmo quem só ouve falar de seu pensamento sente-se incomodado. Os "disparates" de suas ideias afrontam, agridem, geram desconforto. Numa época em que tudo é óbvio, conhecido e dado, só de se possuir essa qualidade, isto é, a capacidade de incomodar, já é algo inestimável. "São os tempos de grande perigo em que aparecem os filósofos" $"$. Há um gérmen para a estranheza nas obras e no pensamento de Heidegger, e algo do tipo urge em nossa época. Ele nos oferece ao menos indicações para a possibilidade de pensarmos o impensado, de minimamente nos depararmos, e concebermos, o impensado. Abrir novas trilhas na floresta do pensamento, de modo a possibilitar outros caminhos, ainda que eles não nos levem a lugar algum.

\footnotetext{
${ }^{59}$ NIETZSCHE, Vontade de poder, $\$ 420$.
} 


\section{Considerações finais}

Diversas campanhas de marketing nos exortam todos os dias a sermos mais digitais e mais conectados. A persuasão dessas campanhas se dá pelo fato de querermos mais agilidade e velocidade na resolução de nossos problemas, mais eficácia, mais praticidade. Problemas imediatos podem ser resolvidos em qualquer lugar, bastando o toque de um dedo em uma tela ou um click, sem a necessidade de filas ou de burocracia. Para as pessoas mais velhas, trata-se de um verdadeiro milagre. Quem conheceu o mundo antes da internet e testemunhou em primeira mão a revolução que ela vem oferecendo à experiência humana, um evento absolutamente sem precedentes na história, encontra-se normalmente confuso e desorientado em meio a tantas novidades ininterruptas, a um progresso tecnológico que implica um processo de obsolescência radical. Nada é feito para durar, pois em pouco tempo já estará disponível uma versão mais nova e aperfeiçoada daquele aparelho. Raramente vale a pena consertar algo que quebra, é melhor já aproveitar para comprar a versão nova e melhorada de uma vez. Esse processo, inquietante para as pessoas mais velhas, que lidavam com coisas duráveis e muitas vezes sabiam fazer reparos básicos nelas quando necessário, já é natural para os que nascem em meio a tudo isso. Nunca deixa de surpreender quando vemos crianças pequenas mexendo intuitivamente e com maior perícia que muitos adultos em celulares e tablets. Nossa reação natural diante disso é a de associarmos a evolução da tecnologia como uma evolução da própria humanidade. Achamos que estamos nascendo cada vez mais inteligentes, mais sagazes.

Curiosamente, essa nossa pretensa esperteza contemporânea que permite com que lidemos com as últimas novidades tecnológicas de modo cada vez mais natural e intuitivo não nos torna nem um pouco capazes de conhecermos o funcionamento de qualquer uma dessas coisas. A maioria absoluta da população mundial que tem acesso a essas tecnologias de ponta não faz a menor ideia de como os aparelhos que usam todos os dias e a todas as horas vieram a ser. Nós sequer paramos para pensar em quais saberes estariam por detrás de cada um desses aparelhos, quais leis da física estão ali pressupostas e atuando constantemente etc. Isso indica que, como nossa compreensão de ser e nosso 
horizonte de sentido, ou seja, nosso mundo, são determinados historicamente, os seres humanos nascidos já em meio a essa revolução tecnológica lidam com os aparelhos de ponta a modo de manual, zuhanden. Eles já pré-compreendem esses aparelhos complexos de modo irrefletido. Em 1927, Heidegger exemplificou a manualidade, o Zuhandenheit, com o martelo ${ }^{1}$. Hoje, em 2017, talvez pudéssemos exemplicá-la com um celular. O modo de ser desses entes na nossa lida cotidiana é o mesmo, por mais que um celular seja muito mais complexo que um martelo. As pessoas mais velhas, que passaram por uma outra determinação história na sua compreensão de ser, que experimentaram um outro modo de lidar com os entes, têm uma dificuldade maior em desvelar os aparelhos tecnológicos no modo de ser da manualidade. Elas encontram-se num constante estado de surpresa diante desses instrumentos. Ao ter que lidar com esses instrumentos, eles deparam-se habitualmente com subsistentes, vorhanden, isto é, eles partem de uma apreensão "teórica" para com essas coisas. Por isso que normalmente as pessoas mais velhas ainda lêem o manual de instruções quando adquirem um aparelho novo, ao passo que os mais jovens já o tiram da caixa sabendo mexer nele até os últimos detalhes sem precisar de nenhuma instrução.

Os avanços tecnológicos causam-nos uma verdadeira sensação de maravilhamento. Tudo hoje é rápido e prático, é eficiente, eficaz. Tais termos compõem os principais slogans do mercado. Deslumbrados por esses ideais, nossa paciência anda cada vez mais curta para com qualquer tipo de lentidão, demora ou atraso. Quando um aparelho trava, dá defeito ou a conexão com a internet cai por alguns instantes, amaldiçoamos o universo como se fôssemos perseguidos pessoalmente pela Fortuna. Tomamos essas coisas como dadas, o que amplia a nossa sensação de dependência para com elas. A vida contemporânea é pautada por um marketing constante. Marketing aqui significa propaganda, divulgação, invenção e venda de ilusões. Nenhuma ação possui valor em si, o valor está no alcance que ela atinge, no quanto ela é compartilhada, vista, aprovada. O mundo se tornou imagem, disse Heidegger, e isso possibilitou com que a ilusão, a aparência, conquistasse o domínio incontestável do real. Não, como visto, a ilusão e a aparência segundo a compreensão platônica dos entes, como sombras das ideias, o ser real. Aparência é o domínio inconteste de uma interpretação do real, a

\footnotetext{
${ }^{1}$ Cf. HEIDEGGER, Ser e tempo, $\S 15$.
} 
absoluta égide da errância. Trata-se de uma aparência porque o ser aparenta ser só o que essa interpretação afirma, e por isso ela permanece inquestionada. Ser é o representável, o que pode ser medido, falseável, dominado. Toda a verdade do ser recai sobre isso, e qualquer consideração de ser que fuja a esses quesitos é tida como falsa, errada, fantasia, mito, "historinha". Ser só aparece de um modo, deste modo, logo só se dá por uma perspectiva, e por isso aparenta ser apenas isso.

O domínio da aparência, a dominação expressa do senso comum, que, como visto, Heidegger chamou de sofística $^{2}$, é, fazendo alusão aos embates platônicos e aristotélicos, o maior dos adversários da filosofia, do pensamento. Com a sofística imperando, a filosofia não tem voz nem vez. E isso porque a própria sofística se apresenta como aparência de filosofia. O senso comum e a "lógica" - entendida como cálculo - como aparência do pensamento. É a maximização da ambiguidade do impessoal. Justamente na época em que consideramos ser mais inteligentes do que jamais fomos, que nunca se pensou tanto como nessa época, é que o pensamento é mais escasso e árduo de ser realizado. Por acharmos que pensamos muito, nem sequer somos capazes de nos questionar o que significa pensar, que dirá pensar de fato.

O domínio da aparência não é somente ontológico, é também ôntico. De fato, a internet já alcançou tamanha complexidade que literalmente bilhões de pessoas encontram-se conectadas em todos os momentos. Tal fato nos dá a aparência de que nunca estamos realmente sozinhos, há sempre alguém conosco do outro lado da tela. Resgatamos contatos com pessoas que não víamos há muitos anos, orgulhamo-nos da quantidade de amigos e seguidores que possuímos nas redes sociais. Inclusive, essa costuma ser a desculpa preferida com que se justifica o excesso de tempo nesses sites: utilizamos eles para manter contato com pessoas das quais havíamo-nos afastado por algum motivo. Por mais que tenhamos esse contato lá adicionado como "amigo", ainda assim nunca falamos nada com ele, e muitas vezes, quando o fazemos, lembramo-nos do porquê ele tinha sido afastado de nossas vidas em primeiro lugar. Basta vermos nosso próprio reflexo patético no ecrã recém apagado após desligarmos o aparelho para nos darmos conta de que estamos, sim, sozinhos, e que aqueles píxels na tela não passam de possibilidades constantes de fuga de nós próprios. Solitários, somos

${ }^{2}$ Cf. HEIDEGGER, A essência da verdade. In: Marcas do caminho, p. 211. 
incapazes de sustentar a solidão. Sempre que temos um momento de absoluto ócio nossos dedos coçam para alcançar o celular e vermos se alguém nos deixou uma mensagem nesse meio tempo. Blaise Pascal, no século XVII, já havia dito:

A única coisa que nos consola de nossas misérias é a diversão. E no entanto é a maior de nossas misérias. Porque é ela que nos impede principalmente de pensar em nós e que nos põe a perder insensivelmente. Sem ela ficaríamos entediados, e esse tédio nos levaria a buscar um meio mais sólido de sair dele, mas a diversão nos entretém e nos faz chegar insensivelmente à morte ${ }^{3}$.

Diversão constante. Entretenimento constante. Novidades constantes. Quanto mais somos capazes de nos dispersar nisso, menos temos que lidar com nossa condição, com nosso próprio. Podemos morrer "em paz", afastando a aparente falta de sentido da vida com prazeres dos mais variados tipos. O marketing é justamente a propaganda desses prazeres advindos da diversão, ele vende as mais variadas possibilidades de diversão como sendo a coisa mais importante de nossas existências. Fazemos também constantemente um marketing pessoal. Somos inclusive incentivados a tal. Precisamos vender uma boa imagem de nós mesmos, precisamos criar uma aparência agradável nossa, de modo que sejamos aceitos por nossos pares. Fabricamos aparências, vivemos de aparências, valorizamos aparências, obedecemos aparências. Mesmo se levarmos em conta o sentido mais banal e rasteiro do que seja "autenticidade", somos inautênticos a todo momento. Afaste a solidão e a morte, abraçe o prazer imediato. Não pense em si, distraia-se com esse novo jogo, esse novo celular e esse novo carro. Há um fenômeno contemporâneo que foi batizado como "Fear of Missing Out", FoMO, que seria algo como um medo de se estar "por fora”. É a sensação de que todos que conhecemos ou "seguimos" nas redes sociais estão aproveitando a vida ao máximo, criando experiências inesquecíveis, enquanto você está desperdiçando a sua vida com frivolidades. É o medo constante de arrependimento, de que estamos tomando as decisões erradas na vida, de que ela está se esvaindo, escorrendo por entre nossos dedos, e nos desesperamos por não conseguirmos impor a ela o rumo que levaria ao que consideramos ser a felicidade. Talvez essa nossa síndrome contemporânea seja a expressão máxima daquilo que Nietzsche chamou de espírito de vingança:

\footnotetext{
${ }^{3}$ PASCAL, Pensamentos, §414, p. 157.
} 
"Foi": assim se chama o ranger de dentes e solitária aflição da vontade. Impotente quanto ao que foi feito - ela é uma irritada espectadora de tudo que passou. A vontade não pode querer para trás; não poder quebrantar o tempo e o apetite do tempo eis a solitária aflição da vontade. (...) Que o tempo não ande para trás, isto a enraivece, "Aquilo que foi" - eis o nome da pedra que ela não pode mover. E assim ela move pedras, por raiva e desalento, e pratica vingança naquele que não sente, como ela, raiva e desalento. Assim a vontade, a libertadora, converteu-se em causadora de dor. (...) Isto, e apenas isto, é a própria vingança: a aversão da vontade pelo tempo e o seu "Foi".

A vingança não é um sentimento contra indivíduos, tiranos, classes sociais; é contra o tempo, o passado, o devir, a mudança, a finitude. Contra a falta de sentido da vida, ou ao menos a falta de evidência de um sentido. Revoltar-se contra o "foi". "Foi daquele modo, mas tinha que ter sido desse"; "Foi assim, mas queria que tivesse sido assado"; "Se eu pudesse voltar no tempo faria tudo diferente...”. Essas lamúrias são tão comuns que as ouvimos e as proferimos constantemente. Todas as escolhas de nossas vidas que nos levaram à dor e sofrimento foram erros, quem dera pudéssemos querer para trás, retornar e fazer diferente, evitar a dor, fugir da dor, nunca sofrer. Estamos sempre tentando estabelecer um novo "marco zero": "Errei desse e daquele modo até aqui, mas a partir de agora não errarei mais, aprendi com meus erros"; "Sofri até este momento, não mais, não sofrerei mais". Por isso apostamos nas promessas da ciência de felicidade futura, que é a que podemos ainda esperar ter, e mentimos e fingimos sobre o nosso passado, de modo a compor uma narrativa de sucesso. Precisamos ser confiantes e bem resolvidos sempre, a sociedade e o mercado o exigem. Aceitar a dor é fraqueza, aceitar sofrer é loucura: mas há muitos medicamentos que resolvem isso.

Expiamos cotidianamente o pecado que foi termos "matado Deus". Estamos abandonados à nossa própria sorte, sozinhos e sem sentido. Essa contingência radical que nos assola e nos "angustia" constantemente precisa ser por nós constantemente afastada, sentimos a necessidade de pensar em qualquer outra coisa que não nisso, qualquer coisa que nos divirta, entretenha e nos disperse no mundo. Mas, tal como os insetos que voam ao redor de uma lâmpada, cuja luz exerce um poder de atração tão irresistível que, por mais que tentem voar para longe, a ela sempre retornam, também conosco a realidade de nossa condição

\footnotetext{
${ }^{4}$ NIETZSCHE, “Da redenção”, Assim falou Zaratustra, II, p. 133.
} 
retorna sempre e insistentemente. Quando achamos que conseguimos nos distanciar o suficiente e que tudo vai ficar bem, é aí que somos puxados de volta com a maior força.

Essa sensação de impotência, de radical carência de poder diante da vida e da Fortuna, é a força motriz de nossa vingança. E o pôr em obra desta vingança passa por um domínio perene e crescente da vida. Um domínio que pressupõe o humano enquanto uma mera base material de afetos, pautado por um princípio utilitarista: obter prazer e afastar a dor em progressões cada vez maiores. Tem-se isso de modo evidente em nossa crescente e quase delirante obsessão pela saúde, de modo a vivermos o máximo sempre - quantitativamente, claro -, e por sonhos de transhumanismo, onde a ciência desvendaria os profundos segredos do ser humano e poderia, enfim, manipulá-lo a seu bel-prazer, evitando doenças, envelhecimento, e, no limite, a morte biológica. É curioso que nunca saibamos o que fazer da vida, que somos assolados constantemente pelo tédio, que estamos sempre a buscar diversões que nos distraiam de nossa condição, mas ainda assim parecemos não hesitar em querer prolongar isso indefinidamente quando somos ofertados com sonhos de imortalidade.

Cada um de nós, hoje, é um conjunto de informações a disposição do mercado. Nossa essência é um emaranhado de dados intercruzados, passíveis de serem transformados em produto, para assim sermos comercializados. Somos Bestand, também nós, humanos. Quem utiliza aparelhos eletrônicos com acesso a internet, seja computador, tablet, celular, relógio etc., tem seus dados coletados por algoritmos e armazenados em um conjunto de dados chamado de Big data. Big data é justamente o nome dado ao todo desse processo de coleta de dados, que captura e armazena nossos dados, possibilitando sua análise, compartilhamento, transferência, visualização, consulta, atualização e privacidade de informações. Isso permite que, cruzando as informações que você voluntariamente oferece aos algoritmos cegos, eles calculem e ofereçam produtos "personalizados", de acordo com o que você costuma comprar, curtir, recomendar. Mesmo a recusa desses produtos serão processadas e adaptadas para que as próximas ofertas sejam ainda mais específicas e irrecusáveis. Soa como algo terrível. De fato. O mais estranho e terrível, contudo, é a sinergia "natural" como isso se dá, que impede que consigamos parar e olhar ao nosso redor de modo inquieto. 
No entanto, aquilo que é verdadeiramente inquietante (eigentlich Unheimliche) não é o facto de o mundo se tornar cada vez mais técnico. Muito mais inquietante (unheimlicher) é o facto de o homem não estar preparado para esta transformação do mundo, é o facto de nós ainda não conseguirmos, através do pensamento que medita, lidar adequadamente com aquilo que, nesta era, está realmente a emergir ${ }^{5}$.

O porquê desta falta de preparo do homem para se tomar como o senhor da Terra passa pela questão fundamental acerca da essência do humano. Tomar o que seja o homem como algo dado e evidente, explicado e explicável pelas diversas ciências, é não só fechar o homem em uma essência, como também, e por causa disso mesmo, manter viva a metafísica "com a ajuda de aparelhos" para que ela vigore e impere, espraiando o esquecimento do ser de modo cada vez mais intenso. Superar a metafísica significa superar o homem. Superar diz: ultrapassar, percorrer por dentro e desde dentro, para daí vislumbrar a luz de uma saída. Precisamos ultrapassar a essência metafísica do humano, de modo grosseiro entendido como animal rationale, animal racional, de modo a sustentarmos outras possibilidades que não a imposta de modo inquestionado, impensado e indisputado. Esse é o mais difícil dos obstáculos: o obstáculo que não se mostra enquanto tal. A ele Nietzsche deu o nome de último homem. O último homem é o que mais persiste e o que mais arduamente será superado. É a última fronteira para o surgimento do super-homem (Übermensch), e por isso o mais perigoso, pois é o mais capaz de impedir que este sequer possa surgir. Deixemos falar Zaratustra sobre o último homem, e atentemos para o quanto ele parece descrever com precisão cirúrgica nosso mundo contemporâneo:

"Que é amor? Que é criação? Que é anseio? Que é estrela?" assim pergunta o último homem, e pisca o olho. A terra se tornou pequena, então, e nela saltita o último homem, que tudo apequena. Sua espécie é inextinguível como o pulgão; o último homem é o que tem a vida mais longa. "Nós inventamos a felicidade" - dizem os últimos homens, e piscam o olho. Eles deixaram as regiões onde era duro viver: pois necessita-se de calor. Cada qual ainda ama o vizinho e nele se esfrega: pois necessita-se de calor. Adoecer e desconfiar é visto como pecado por eles: anda-se com toda a atenção. Um tolo, quem ainda tropeça em pedras ou homens! Um pouco de veneno de quando em quando: isso gera sonhos agradáveis. E muito veneno por fim, para um agradável morrer. Ainda se trabalha, pois trabalho é distração. Mas cuida-se para que a distração não canse. Ninguém mais se torna rico ou pobre: ambas as coisas são

\footnotetext{
${ }^{5}$ HEIDEGGER, Serenidade, p. 21.
} 
árduas. Quem deseja ainda governar? Quem deseja ainda obedecer? Ambas as coisas são árduas. Nenhum pastor e um só rebanho! Cada um quer o mesmo, cada um é igual: quem sente de outro modo vai voluntariamente para o hospício. "Outrora o mundo inteiro era doido" - dizem os mais refinados, e piscam o olho. São inteligentes e sabem tudo o que ocorreu: então sua zombaria não tem fim. Ainda brigam, mas logo se reconciliam - de outro modo, estraga-se o estômago. Têm seu pequeno prazer do dia e seu pequeno prazer da noite: mas respeitam a saúde. "Nós inventamos a felicidade" - dizem os últimos homens, e piscam o olho. $-^{6}$

Isso pode soar engraçado, como um deboche refinadíssimo, uma ironia fina. Mas, se rimos, é porque nos reconhecemos ridículos. Nós somos o último homem. Por conta disso, por mais que todas as considerações sobre a tecnologia feitas acima pareçam ter um caráter marcadamente negativo e condenatório, a tecnologia não é o problema. Heidegger não poderia ter sido mais claro quanto a isso:

Para todos nós os equipamentos, aparelhos e máquinas do mundo técnico são hoje imprescindíveis, para uns em maior e para outros em menor grau. Seria insensato investir às cegas contra o mundo técnico. Seria ter vistas curtas querer condenar o mundo técnico como uma obra do diabo. Estamos dependentes dos objectos técnicos que até nos desafiam a um sempre crescente aperfeiçoamento ${ }^{7}$.

A questão não é o domínio da técnica per se. A questão é sermos o último homem e parecermos incapazes de nos apercebermos disso. $\mathrm{O}$ homem que entende sua essência como razão, cujo pensamento é majoritariamente cálculo, eis o homem que tomou para si a tarefa do domínio planetário. O domínio da técnica, que desafia este homem, permite que sua própria essência seja apreendida de modo técnico. Vê-se o homem tecnicamente, e concebe-se a técnica tecnicamente. Quando esse domínio assim se impõe, ele erradica quaisquer possibilidades de se pensar a essência da técnica. O sentido da técnica permanecerá velado enquanto não nos dermos conta de que a técnica não é nada de técnico, ontologicamente. Não é criação nossa, não é nossa serva. Nós que somos moldados por ela, para a ela melhor servirmos. Somente seremos capazes de vislumbrar o mistério da essência da técnica se estivermos dispostos de certo modo. Heidegger flerta com diversas possibilidades de disposições que, oscilando entre si, caracterizariam aquilo que seria a disposição fundamental para o outro pensar que urge em nossa

\footnotetext{
${ }^{6}$ NIETZSCHE, Assim falou Zaratustra, Prólogo, 5, pp. 18-19.

${ }^{7}$ HEIDEGGER, Serenidade, p. 23.
} 
época. De modo preliminar, elas seriam concebidas como o susto (das Erschrecken), a retenção (die Verhaltenheit) e o pudor (die Scheu).

$O$ susto (...) é a viagem de volta do caráter corrente do comportamento no familiar para a abertura do acometimento do que se encobre, em cuja abertura o que há até aqui de corrente se revela ao mesmo tempo como o estranho e como o agrilhoante. O que há de mais corrente, porém, e, por isso, mais desconhecido, é o abandono do ser. $\mathrm{O}$ assustar-se deixa que o homem volte ao fato de que o ente é, enquanto anteriormente o ente para ele era justamente o ente (...). Todavia, esse susto não é nenhum mero recuo, nem tampouco a abdicação perplexa da "vontade", mas, como nele precisamente o encobrir-se do seer se abre e o ente mesmo e a referência a ele se veem inclinados a serem conservados, se associa com esse susto a partir dele mesmo a "vontade" que lhe é mais própria, e essa é aquilo que se denomina aqui a retenção. A retenção, a tonalidade afetiva prévia da prontidão para a recusa como doação. Na retenção vigora, sem afastar nenhuma viagem de volta, o dirigir-se para o privar-se hesitante como a essenciação do seer. A retenção é o meio para o susto e o pudor. (...) O pudor, porém, segundo o que foi dito, não pode ser confundido com a timidez ou ser mesmo apenas compreendido na direção da timidez. (...) Para o pudor em particular, emerge a necessidade do silenciamento, e essa necessidade é o deixar essenciar-se que afina completamente toda postura em meio ao ente e todo comportamento em relação ao ente . $^{8}$.

Embora a primeira vista possamos entender que a disposição fundamental de nossa época seja múltipla, isso não é exatamente o caso. Esses nomes supracitados se copertencem de modo essencial, de modo a trazer a tona a simplicidade da disposição de ânimo fundamental. A retenção seria como que um "primeiro passo", a primeira etapa de apropriação dessa disposição fundamental. Nunca é demais repetir que essa disposição não é nada de psicológico, nem nada do âmbito das vivências, não é nada causado por experiências empíricas. Assim, a retenção seria o meio pelo qual a disposição nos dispõe no mundo como prontidão para a recusa, recusa aqui das coisas de nosso âmbito familiar e cotidiano enquanto tais. Seria o mesmo que a prontidão para a angústia em Ser e tempo, mas agora de modo mais precisamente contextualizado historicamente. A retenção é a coragem da recusa que possibilita a doação de nosso próprio, ou seja, a criação que nos transcende. Por meio da retenção, podemos ser tocados e tomados pelo susto, susto não como o assustar-se e amedrontrar-se com algum ente intramundano, não nos assustamos com nenhuma coisa específica ou situação

\footnotetext{
${ }^{8}$ HEIDEGGER, Contribuições à filosofia, §5, pp. 19-20, tradução modificada.
} 
ôntica, mas sim o susto como aquela reminiscência do espanto que é a própria origem da filosofia, o espanto para com a presença do ser nas coisas, o susto para com a estranheza radical do ser em meio ao familiar e habitual do ente. A recusa do "mundo" originada pela retenção permite que nos assustemos com o mundo enquanto tal, e isso pode possibilitar o resgate daquela primeira relação com os entes que fundou a história. Assustados diante do mistério do ser que há muito havíamos nos esquecido, podemos ser capazes de nos dispormos com veneração diante do mistério, e sustentar o silêncio que a dominação expressa do falatório e da publicidade haviam obliterado. É isso o pudor: o respeito diante do sagrado e a sustentação do silêncio que a ele convém.

Retenção, susto e pudor, por conseguinte, perfazem em uma intrinsecabilidade recíproca a disposição fundamental que sempre estará para além de qualquer mero nome. Mas a retenção parece ser o aspecto mais originário, sendo por isso o meio e a origem das demais. Retenção, Verhaltenheit, diz literalmente o caráter próprio do comportamento (Verhalten). Nosso comportamento para com as coisas, que se dá no nexo de compreensão e interpretação, é o ponto de partida. Pois ele é o mais imediato, que põe os demais existenciais em evidência. $\mathrm{O}$ comportamento dita e fundamenta a insistência do ser-aí em seu aí. Por conta disso, Heidegger assevera:

\begin{abstract}
A retenção é o fundamento do cuidado. A retenção do ser-aí fundamenta pela primeira vez o cuidado como a insistência que suporta o aí. Mas o cuidado (...) não tem em vista a aflição e a opressão, nem tampouco a preocupação atormentada em torno disto e daquilo. (...) Enquanto insistência do ser-aí, cuidado é a decisão antecipadora da verdade do ser e o aprisionamento que suporta, sobretudo, algo referido no aí; o fundamento desse "sobretudo" é a retenção do ser-aí".
\end{abstract}

A retenção, por conseguinte, é a origem da tranquilidade que advém da manifestação do cuidado em seu sentido radical. A essa tranquilidade Heidegger deu o nome de serenidade (die Gelassenheit). Dispostos desse modo, tendo serenidade para com as coisas, podemos "tirar proveito" da recusa. A serenidade é originada pela retenção que possibilita o susto e o pudor, mas é também, ao mesmo tempo, seu fundamento. Esse todo, conquanto pareça complexo, é na verdade radicalmente simples. Essa é a disposição de ânimo fundamental de nossa era. Serenidade é um modo de abdicação. Mas essa abdicação não é um deixar de

\footnotetext{
${ }^{9}$ Idem, ibidem, $\S 13$ pp. 38-39.
} 
lado com descaso, um abrir mão forçado dos aparelhos tecnológicos e do conforto da vida contemporânea. Pelo contrário, a abdicação da serenidade é a mais elevada forma de posse. Heidegger fala da serenidade como um dizer simultaneamente "sim" e "não" aos objetos técnicos, e, desse modo,

A nossa relação com o mundo técnico torna-se maravilhosamente simples e tranquila. Deixamos os objetos técnicos entrar no nosso mundo quotidiano e ao mesmo tempo deixamo-los fora, isto é, deixamo-los repousar em si mesmos como coisas que não são algo de absoluto, mas que dependem elas próprias de algo superior ${ }^{10}$.

A serenidade nos permite o modo mais elevado de possuirmos os objetos técnicos porque ela funda e se funda na retenção que possibilita a recusa desses objetos. Quando a serenidade nos dispõe no "mundo" cotidiano determinado pela tecnologia, somos capazes de dizer "não" juntamente com o "sim". Dizer apenas "não", bem como dizer apenas "sim", são comportamentos do âmbito do impessoal. Nossa tendência, ao nos refugiarmos no conforto do hábito, é seguirmos o que ele impõe. Primariamente, portanto, dizemos "sim" a tudo de modo automático, sem contestar. Mas a consciência disso também pode fazer com que nos horrorizemos do domínio e de nossa dependência para com a tecnologia como se horroriza, fugir dos grandes centros urbanos onde tal domínio é mais evidente como se foge, achar-se superior aos outros porque não precisa de tantos aparelhos em sua vida tal como a gente se acha. A pura negação nada mais é que a inversão da pura afirmação, e justamente por isso não toca em nada de essencial. Ela ainda é regida pelo impessoal.

Somente a disposição de ânimo fundamental, que não inverte, mas suspende, pode possibilitar o entre, o meio termo. Sustentar a tensão desse entre é a experiência da estranheza. É não deixar o mundo para trás, mas perceber o experimentar do mundo enquanto tal. É não se perder numa solidão no sentido de um solipsismo, mas perceber o ser-aí enquanto ser-aí, dar-se conta de seu próprio, e da responsabilidade dessa tarefa. Tomados pela serenidade, podemos tomar consciência de nosso próprio, do que realmente importa, e por isso podemos de fato possuir aparelhos tecnológicos, pois desse modo nunca serão eles que nos possuirão. É nesse sentido que ela permite o sentido mais elevado de posse. Somente sustentando essa tensão somos capazes da recusa que não simplesmente

\footnotetext{
${ }^{10}$ HEIDEGGER, Serenidade, p. 24.
} 
diz "não", mas que doa, que nos abre para a gratidão do mistério. Criar, e ser capaz de largar. Suportar a criação no abismo. Desse modo, não ficaremos com medo de estarmos desperdiçando a vida, não ficaremos achando que a existência é insuficiente. Tendo o mais elevado sentido de posse, temos também o real sentido da pobreza. Não buscaremos mais vingança pelo "foi”, pois “todo 'Foi' é um pedaço, um enigma, um apavorante acaso - até que a vontade criadora fala: 'Mas assim eu quis!",11.

Embora sempre de modo insuficiente, pois a imensidão da tarefa é, e talvez sempre será, inconcebível, o pensamento de Heidegger nos oferece elementos para que ao menos possamos pôr em questão o quê, afinal de contas, estamos fazendo, fazendo com o mundo, com a existência, com a Terra, com o homem, com o ente na totalidade. Nada aqui é uma resposta dada de como poderemos "nadar contra a corrente". Não adianta passarmos os olhos por sua obra e "tomarmos uma decisão" de nos retermos, de recusarmos a vida fundamentada na tecnologia, de nos assustarmos com a rapidez de seus avanços, de termos vergonha do que estamos fazendo, de sermos serenos a bel prazer. Nada disso seria uma experiência de pensamento, experiência pensante. A era da tecnologia e o domínio da ciência não são coisas que poderão ser resolvidas por meio do diálogo entre pessoas, nenhuma conferência de cientistas poderá decidir pelo seu fim ou por uma guinada em outra direção. Não há nem nunca haverá uma "solução", nesse sentido. O máximo que Heidegger pode nos exortar é que, diante do chamado do ser, quando e se isso ocorrer, possamos a ele responder apropriadamente. Fazer o homem histórico "tornar-se fundador e o guardião da verdade do seer (der Gründer und Wahrer der Wahrheit des Seyns zu werden)"12. A tarefa é, mais uma vez, sermos capazes de superar o homem, e, por conseguinte, a metafísica. E isso só será possível a partir de um pensamento que pensa a essência do humano de modo fundamental. É fundamental pensarmos o ser-aí enquanto ser-aí, cuja essência é o cuidado. "Ser o que busca, o que vela, o que guarda - isto significa o cuidado enquanto traço fundamental do ser-aí. (Sucher, Wahrer, Wächter sein - das meint die Sorge als Grundzug des Daseins)"13.

\footnotetext{
${ }^{11}$ NIETZSCHE, "Da redenção", Assim falou Zaratustra, II, p. 134.

${ }^{12}$ HEIDEGGER, Contribuições à filosofia, §5, p. 20.

${ }^{13}$ Idem, ibidem, §5, p. 21.
} 


\section{Referências bibliográficas}

\subsection{Fontes primárias}

HEIDEGGER, Martin. A caminho da linguagem. $6^{\mathrm{a}}$ ed. Trad. Márcia Sá Cavalcante Schuback. Petrópolis: Vozes, 2012.

. Basic questions of philosophy. Trad. Richard Rojcewicz e André Schuwer. Indianapolis: Indiana University Press, 1994.

. Conceitos fundamentais da Metafísica, Os: mundo, finitude, solidão.

Trad. Marco Antônio Casanova. Rio de Janeiro: Forense Universitária, 2011.

. Contribuições à filosofia: do acontecimento apropriador. Trad. Marco

Antônio Casanova. Rio de Janeiro: Via Verita, 2015.

. Ensaios e conferências. Trad. Emmanuel Carneiro Leão, Gilvan Fogel e

Marcia Sá Cavalcante Schuback. Petrópolis: Vozes, 2001.

. Essência do fundamento, A. Lisboa: Edições 70, 2007.

. Essência da liberdade humana, A: introdução à filosofia. Trad. Marco

Antônio Casanova. Rio de Janeiro: Via Verita, 2012.

Introdução à metafísica. Trad. Mário Matos e Bernhard Sylla. Lisboa:

Instituto Piaget, 1997.

- Marcas do caminho. Trad. Enio Paulo Giachini e Ernildo Stein.

Petrópolis: Vozes, 2008.

. Nietzsche. Vol. único. Trad. Marco Antônio Casanova. Rio de Janeiro:

Forense Universitária, 2014.

. Que é isto - a filosofia? Identidade e Diferença. $3^{\mathrm{a}}$ ed. Trad. Ernildo Stein. Petrópolis: Vozes, 2006.

. Ser e tempo. Trad. Márcia Sá Cavalcante Schuback. $6^{\mathrm{a}}$ ed. Petrópolis:

Vozes, 2006.

. Ser e tempo. Trad. Fausto Castilho. São Paulo; Petrópolis: Unicamp;

Vozes, 2012. 
. Serenidade. Trad. Maria Madalena Andrade e Olga Santos. Lisboa: Instituto Piaget, s./d.

. What is a thing? Trad. W. B. Barton e Vera Deutsch. Indiana: Gateway, 1967.

\subsection{Fontes secundárias}

AGAMBEN, Giorgio. O tempo que resta: um comentário à Carta aos Romanos. Trad. Davi Pessoa e Cláudio Oliveira. Belo Horizonte: Autêntica, 2016.

AgOstinHO. Confissões. Trad. J. Oliveira Santos e A. Ambrósio de Pina. São Paulo: Abril Cultural, 1973 (Os Pensadores).

ARISTÓTELES. Ética a Nicômaco. São Paulo: Abril Cultural, 1973 (Os Pensadores).

. Metafísica. Trad. Marcelo Perine. São Paulo: Loyola, 2002.

. Órganon. Trad. Edson Bini. 2a ed. Bauru: Edipro, 2010.

. Retórica. Trad. Manuel Alexandre Júnior; Paulo Farmhouse Alberto;

Abel do Nascimento Pena. São Paulo: Martins Fontes, 2013.

DESCARTES, René. Discurso do método. Trad. Maria Ermantina de Almeida Prado Galvão. São Paulo: Martins Fontes, 2011. Meditações metafísicas. Trad. J. Guinsburg e Bento Prado Júnior. São Paulo: Abril Cultural, 1973 (Os Pensadores).

. Regras para a direção do espírito. Lisboa: Edições 70, s./d.

DIÓGENES LAÉRCIO. Vidas e doutrinas dos filósofos ilustres. $2^{\mathrm{a}}$ ed. Trad. Mário da Gama. Brasília: UNB, 2008.

FREUD, Sigmund. "O Homem dos Lobos" e outros textos (1917-1920). Trad.

Paulo César de Souza. São Paulo: Companhia das Letras, 2010.

HERÁCLITO. Fragmentos contextualizados. Trad. Alexandre Costa. São Paulo: Odysseus, 2012.

HESÍODO. Teogonia. Trad. Jaa Torrano. São Paulo: Iluminuras, 2015. 
HÖLDERLIN, Friedrich. Sämtliche Werke. Vol. 2. Stuttgart: Kohlhammer, 1954.

HUME, David, Tratado da natureza humana. $3^{\mathrm{a}}$ ed. Lisboa: Fundação Calouste Gulbenkian, 2012.

KANT, Immanuel. Crítica da razão pura. $8^{\mathrm{a}}$ ed. Trad. Manuela Pinto dos Santos e Alexandre Fradique Morujão. Lisboa: Fundação Calouste Gulbenkian, 2013. . Manual dos cursos de lógica geral. Trad. Fausto Castilho. São Paulo: UNICAMP, 2012.

LORENZ, Günter. Diálogo com a América Latina. São Paulo: E.P.U., 1973.

KIERKEGAARD, Søren. As obras do amor: algumas considerações cristãs em forma de discursos. $3^{\mathrm{a}}$ ed. Trad. Álvaro Valls. Petrópolis: Vozes, 2012.

MESTRE ECKHART. Sermões alemães. Vol. 2. Trad. Enio Paulo Giachini. Petrópolis: Vozes, 2008.

NIETZSCHE, Friedrich. Além do bem e do mal. Trad. Mário Ferreira dos Santos. Petrópolis: Vozes, 2013. - Assim falou Zaratustra. Trad. Paulo César de Souza. São Paulo: Companhia das Letras, 2011.

: Crepúsculo dos ídolos. Trad. Paulo César de Souza. São Paulo: Companhia das Letras, 2006.

. Gaia ciência, A. Trad. Paulo César de Souza. São Paulo: Companhia das Letras, 2012.

. Nascimento da tragédia, O. Trad. J. Guinsburg. São Paulo: Companhia das Letras, 2007.

. Vontade de poder. Trad. Marcos Sinésio Fernandes e Francisco José de Moraes. Rio de Janeiro: Contraponto, 2008.

PASCAL. Pensamentos. Trad. Mario Laranjeira. São Paulo: Martins Fontes, 2005.

PESSOA, Fernando. Alguma prosa. Rio de Janeiro: Nova Fronteira, 1990.

PLATÃO. Banquete. Trad. Carlos Alberto Nunes. Belém: UFPA, 2011. Diálogos. Trad. Carlos Alberto Nunes. Belém: UFPA, 1985. 
. Fedro. Trad. Carlos Alberto Nunes. Belém: UFPA, 2011.

. Mênon. Trad. Maura Iglésias. Rio de Janeiro; São Paulo: PUC-Rio;

Loyola, 2001.

. Teeteto. Trad. Adriana Manuela Nogueira; Marcelo Boeri. $3^{\mathrm{a}}$ ed. Lisboa:

Calouste Gulbenkian, 2010.

ROSA, João Guimarães. Noites do sertão. $9^{\mathrm{a}}$ ed. Rio de Janeiro: Nova Fronteira, 2001 .

SNELL, Bruno. A cultura grega e as origens do pensamento europeu. Trad.

Pérola de Carvalho. São Paulo: Perspectiva, 2012.

TARSKI, Alfred. A concepção semântica da verdade. Trad. Cezar Augusto Mortari e Luiz Henrique Dutra. São Paulo: UNESP, 2007.

TOMÁS DE AQUINO. Verdade e Conhecimento. Trad. Luiz Jean Lauand; Mario Bruno Sproviero. São Paulo: Martins Fontes, 2013.

\subsection{Outras referências}

Bíblia Sagrada. Trad. Ivo Storniolo, Euclides Balancin e José Luiz do Prado. São Paulo: Paulus, 2000.

BERGSON, Henri. O riso: ensaio sobre a significação do cômico. $2^{\mathrm{a}}$ ed. Trad. Nathanael Caixeiro. Rio de Janeiro: Zahar, 1983.

BORGES, Jorge Luis. Fiç̧ões. Trad. Davi Arrigucci Jr. São Paulo: Companhia das Letras, 2007.

BORNHEIM, Gerd. Introdução ao filosofar: o pensamento filosófico em bases existenciais. $11^{\mathrm{a}}$ ed. São Paulo: Globo, 2003.

CHANTRAINE, Pierre. Dictionnaire Étymologique de la Langue Grecque. Paris: Klincksieck, 1968.

PESSOA, Fernando. Poesia completa de Álvaro de Campos. São Paulo: Companhia das Letras, 2007. 